OL. 


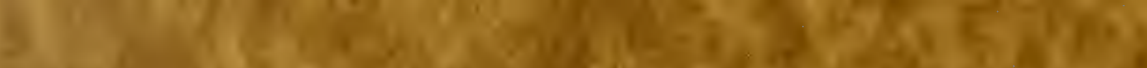

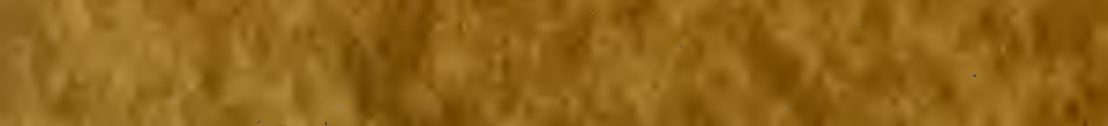

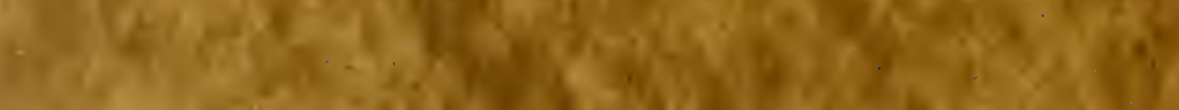
whomerwas of vasubse

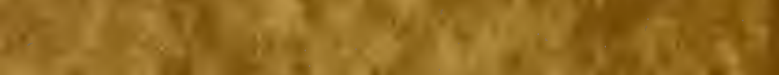

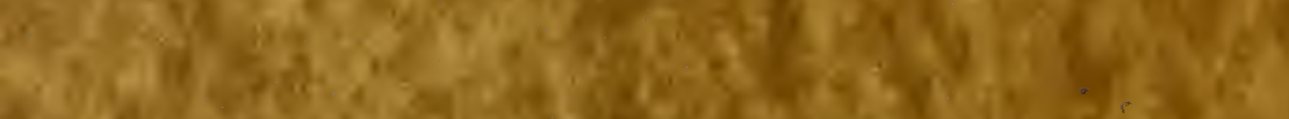

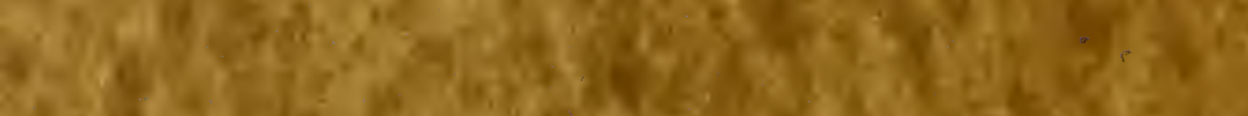

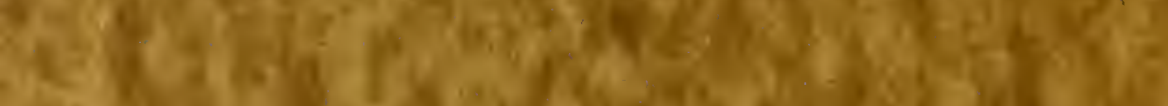

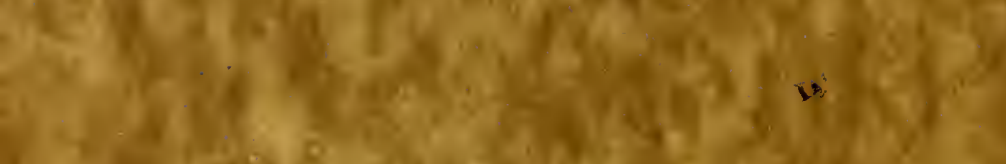

(i) 1.

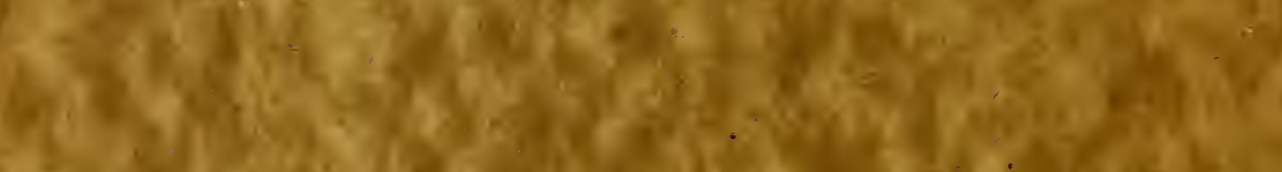

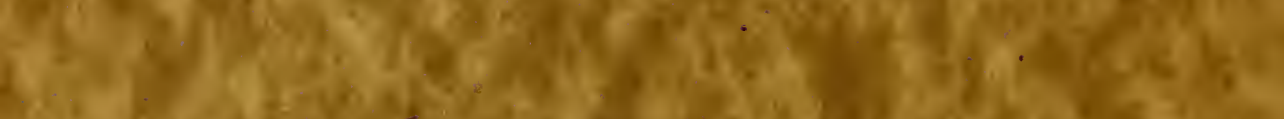

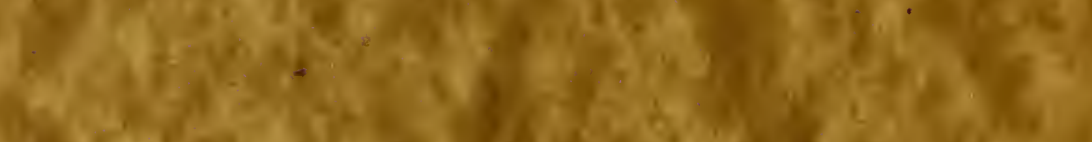

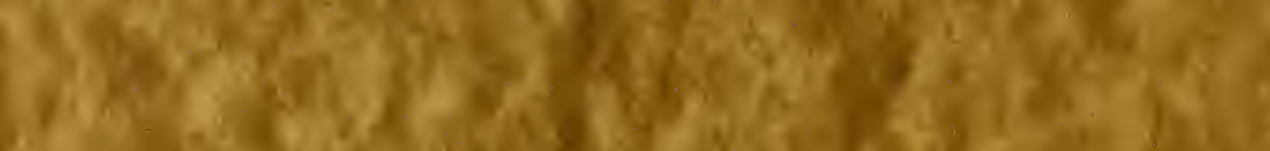
W.

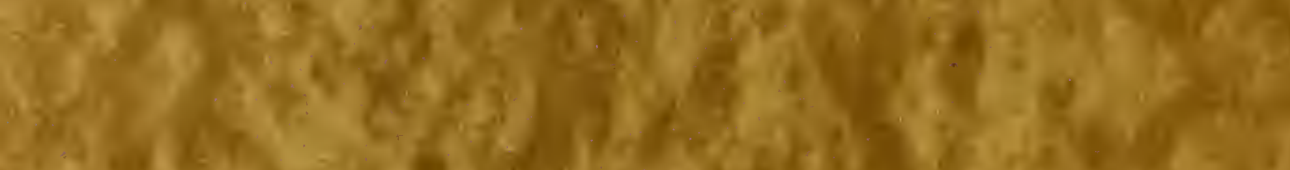

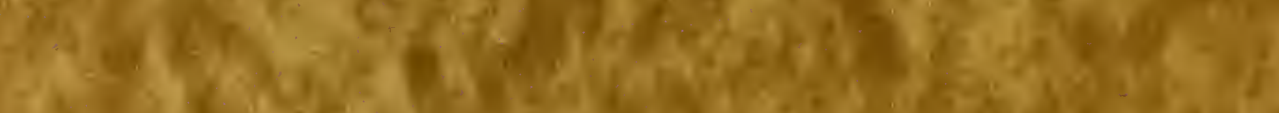

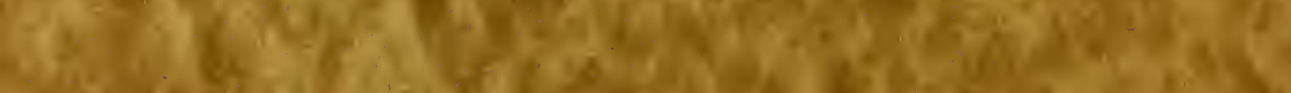

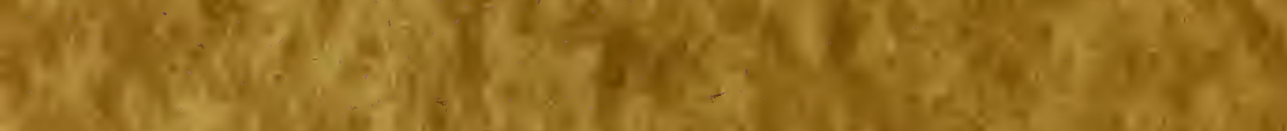
is

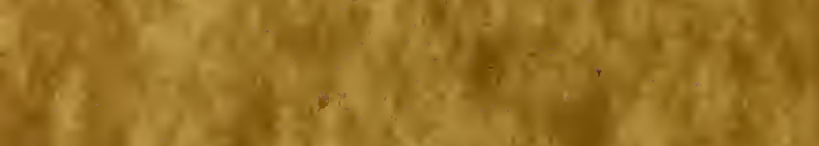

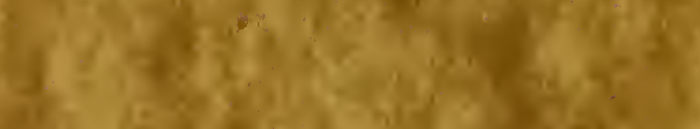

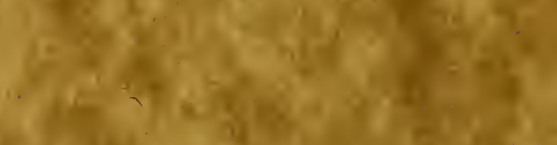

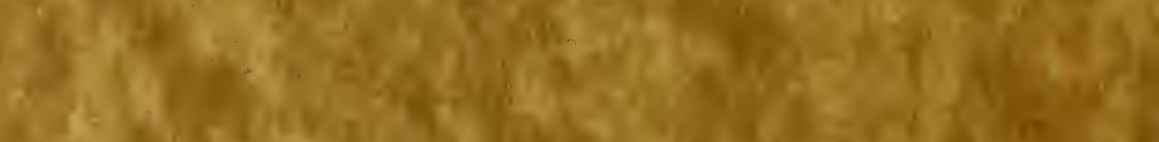

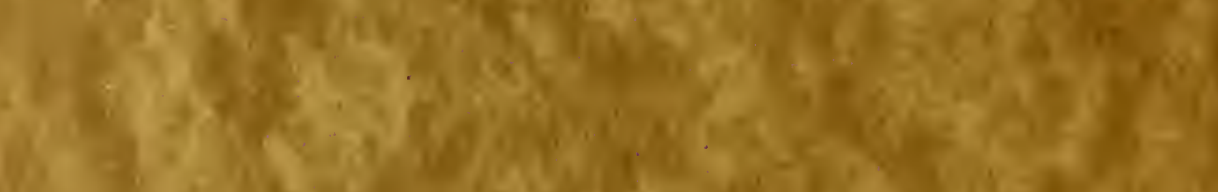
6. 


\section{REPRINTED FROM}

Volume VII, Numbers 11-12, Pages 597-708, OF THE

Monthly Bulletin of the State Commission of Horticulture

\section{NATURAL HISTORY}

UF THE

\section{GROUND SQUIRRELS}

\section{OF CALIFORNIA}

By JOSEPH GRINNELL and JOSEPH DIXON

Contribution from the University of California

Museum of Vertebrate Zoology

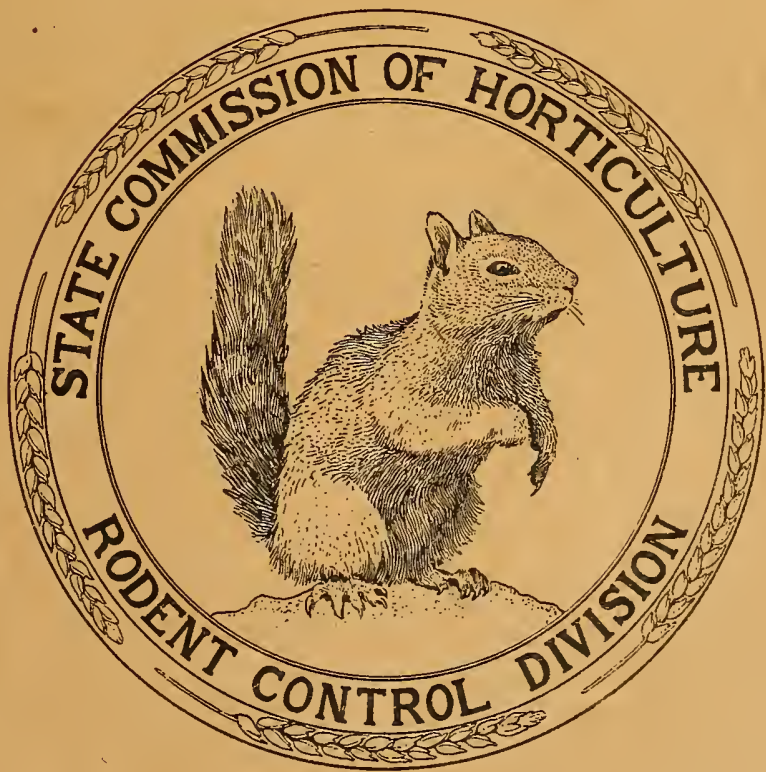



REPRINTED FROM

Volume VII, Numbers 11-12, Pages 597-708,

OF THE

Monthly Bulletin of the State Commission of Horticulture

\section{NATURAL HISTORY}

OF THE

\section{GROUND SQUIRRELS}

\section{OF CALIFORNIA}

By JOSEPH GRINNELL and JOSEPH DIXON III

Contribution from the University of California Museum of Vertebrate Zoology 


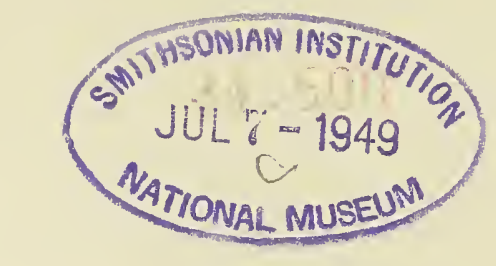




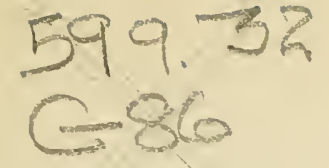

\section{CONTENTS.}

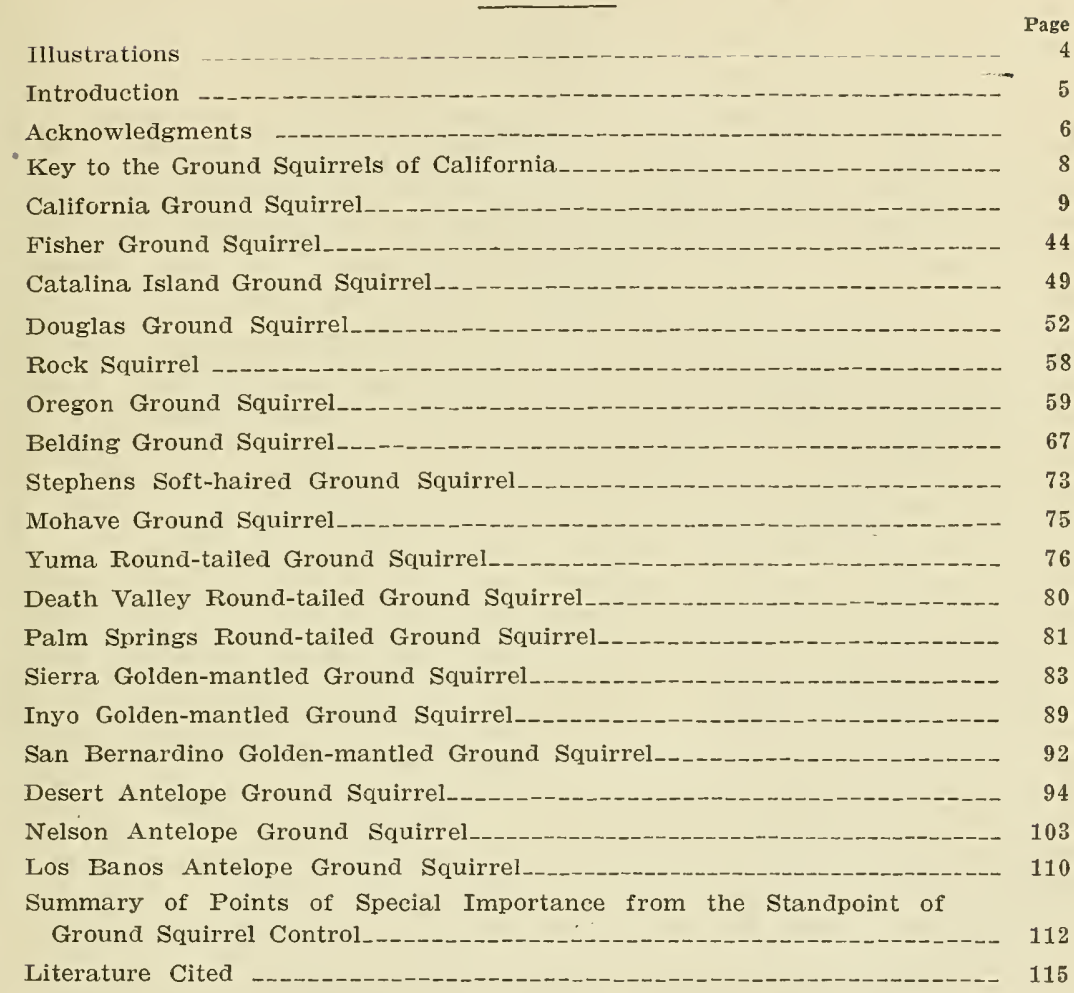

Note.-Figures indicating page numbers refer to folios at foot of pages 


\section{ILLUSTRATIONS.}

PLATES.

PAGE

Plate 1. California Ground Squirrels

Plate 2. Douglas Ground Squirrel and Oregon Ground Squirrel____.._-_-_-_-_ 52

Plate 3. Belding Ground Squirrel and Sierra Golden-mantled Ground Squirre1_- 70

Plate 4. Yuma Round-tailed Ground Squirrel and Mohave Ground Squirrel__-_ 76

Plate 5. Desert Antelope Ground Squirrel and Fisher Ground Squirrel_._._... 98

FIGURES IN TEXT.

Fig. 1. Ears of several species of ground squirrels

Fig. 3. Four characteristic poses of a California Ground Squirrel

Fig. 4. Mound and burrow entrance of a California Ground Squirrel___..._ 16

Fig. 5. "Hog-wallow" land, showing burrow of the California Ground Squirrel_ 18

Fig. 6. Plot of excavated burrow of a male "digger" squirrel_____________ 19

Fig. 7. Plot of excavated nesting burrow of a female "digger" squirrel__._. 20

Fig. 8. Plot of excavated coloniel burrow-system of "digger" squirrel_____._. 21

Fig. 9. Nest of male "digger" squirrel

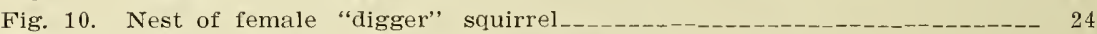

Fig. 11. Nest and small young of "digger" squirrel

Fig. 12. Diagram showing extent and height of breeding season in California Ground Squirrel _.

Fig. 13. Drawings to show relative extent of cheek-pouches in California and Belding Ground Squirrels____.

Fig. 14. Heads of wheat gathered by one "digger" squirrel

Fig. 15. Metropolis of "digger" squirrels in a grain field______._.

Fig. 16. Badly infested hillside _.___._. 41

Fig. 17. Map showing distribution of the "digger" squirrels _-_-_._-_-_-_.- 46

Fig. 18. Map showing distribution of the Oregon, Belding, Stephens Soft-haired and the Round-tailed Ground Squirrels___-

Fig. 19. Plot of excavated nesting burrow of Oregon Ground Squirrel_._-_._-_ 64

Fig. 20. Life photographs of Oregon, Belding and Sierra Golden-mantled Ground Squirrels

Fig. 21. Plot of excarated burrow of female Belding Ground Squirrel_..._._. 71

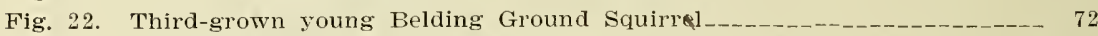

Fig. 23. Diagram showing the ranges of California Ground Squirrels according to life-zones 78

Fig. 24. Map showing distribution of the Golden-mantled and Antelope Ground Squirrels _._.

Fig. 25. Hibernating San Bernardino Golden-mantled Ground Squirrel _.......

Fig. 26. Feet of Desert Antelope, Stephens Soft-haired and California Ground Squirrels, to show tubercles and extent of hairing

Fig. 27. Young Desert Antelope Ground Squirrel_________-_-_-_-__-__-- 101

Fig. 28. Young Nelson Antelope Ground Squirrel____-_____-_-_-_-_-__-_ 106

Fig. 29. Adult pair of Nelson Antelope Ground Squirrels _._______________ 107

Fig. 30. Diagram showing relative economic importance of different ground squirrels

Note.-Figures indicating page numbers refer to folios at foot of pages. 


\title{
NATURAL HISTORY OF THE GROUND SQUIRRELS OF CALIFORNIA.
}

\author{
BY JOSEPH GRINNELL and JOSEPH DIXON.
}

Contribution from the Museum of Vertebrate Zoology, of the University of California.

\section{INTRODUCTION.}

Human occupancy of a new country always tends to upset the primitive balance of things. Man either purposefully or incidentally begins at once to modify the original complement of animal and plant life both through destruction of native species and by bringing in with him alien kinds. Some native species become more and more restricted in range, even disappearing altogether; others tend to increase and spread, finding conditions for their existence to be improved through man's activities.

In the case of the ground squirrels of California, we have a group of mammals which seems to have in many places benefited by human invasion. This is probably due to the destruction by man of the many predatory animals, such as hawks, eagles, coyotes and badgers, which under original conditions kept the small herbivorous mammals in check, and in part to the improved food supply made available to the ground squirrels through his cultivation of crops. Because of the destructiveness of these rodents to the planted crops and native forage upon which man is dependent to a large extent directly or indirectly for his own food supply, the problem of ground squirrel control has become one of very immediate agricultural and pastoral importance.

It would seem that knowledge, as full as possible, of the ground squirrels of California is necessary to determining the most successful means of controlling them and to applying these means properly to the varying conditions throughout our state. This knowledge should include the main distinctions by which each may be known from its relatives, the distribution of each of the species, the extent of the bur rows, the breeding rate, the food habits, and, indeed, every other class of facts obtainable relative to their natural history. It is not often apparent, in advance, which facts will and which will not prove of critical importance in economic work.

To illustrate the value of a thorough knowledge of the food habits of the animal in question, when the most efficient method of controlling destructive rodents is sought, we need only to point to the present method used in poisoning the California Ground Squirrel by the use of barley coated with strychnine, rather than barley soaked in a strychnine solution. By applying a knowledge of the food habits of this animal it was possible greatly to increase the effectiveness of poisoned grain because of the discovery by Stanley E. Piper, of the United States Biological Survey, that this squirrel is more readily poisoned through the membranous walls of its cheek-pouches when merely carrying the poisoned grain than through the stomach after the poisoned grain has been eaten. Strychnine-coated barley has not, however, been found 
so successful when applied to the Oregon Ground Squirrel, which animal apparently does not habitually gather and store seeds and grain to a large extent, but is active chiefly during the spring and early summer when green vegetation, upon which it depends for food, is to be had. Some sort of green baits might be expected to be more effective with this species.

It is very desirable at this time that we know more about the extent of æstivation and hibernation among our ground squirrels. We know little or nothing of the effect of gases upon squirrels in this condition; and it is obvious that such part of a squirrel population as is dormant at the time of a poison campaign will escape destruction and become a nucleus of reinfestation.

During the past spring and summer our work of excavating squirrel burrows after the occupants had been gassed, has shown that one frequent cause of failure in the ordinary waste-ball method of applying carbon bisulphid is due to the fact that sudden elevation in the course of the burrow, of as much as two feet in some cases, prevents the heavy gas from reaching the animal. This condition was found to occur much more frequently than is generally supposed.

The instances just cited all suggest that the present knowledge of our ground squirrels is far from complete, and they serve to emphasize the above contention that a more thorough knowledge of this subject is essential to securing the most intelligent and efficient methods of control of these our chief rodent pests. It is the purpose of the present paper to supply the information available from all sources in as much detail as it has proven feasible for the authors to secure it at this time. The facts and inferences are given just as they came, irrespective of whether or not they show obvious and immediate economic bearing. They are here available to everyone who is concerned with methods of control.

\section{ACKNOWLEDGMENTS.}

The present paper has been prepared at the suggestion of Mr. G. H. Hecke, California State Commissioner of Horticuiture, and Mr. W. C. Jacobsen, Superintendent of Rodent Control under this commission. Both these men have rendered many valuable helps during the progress of our work and have co-operated to facilitate its final publication. Their emphasis all along has been upon the need of a summary of the facts relative to rodent natural history at this particular time, when efforts from every direction are being concentrated upon the problem of increased crop production.

Upon the facilities and auspices of the Museum of Vertebrate Zoology of the University of California the writers have been dependent for the opportunity of carrying through their undertaking; and behind this has been the continual financial and moral support of the founder and constant patron of the Museum, Miss Annie M. Alexander. The collections of specimens and the field records contained in this Museum, gathered during the past ten years, have been absolutely indispensable 
to the present accomplishment. A total of 1263 study skins of ground squirrels taken within this state have been examined in the course of our work.

In the spring and summer of 1911, two field assistants from the United States Public Health and Marine-Hospital Service were assigned by Dr. Rupert Blue, then Surgeon in Command, San Francisco, to accompany the Museum party working in south-central California, for the purpose of increasing the common knowledge of the distribution and manner of occurrence of the rodents of the region. Acknowledgment is here made for the use of certain facts from the manuscript repol't of that year's work made to Dr. Blue by the Director of the Museum.

During the past year, Dr. W. C. Billings, Surgeon, in temporary charge, United States Public Health Service, San Francisco, has very greatly aided us in having his field men send us specimens of ground squirrels, both alive and dead, for experimentation and study.

To Professor Harvey M. Hall, of the University of California, we are indebted for identifying numerous seeds obtained from the cheekpouches of ground squirrels.

Through special provision of the State Commissioner of Horticulture we have been fortunate in being able to have the accompanying five colored plates of ground squirrels drawn by the eminent animal artist, Mr. Louis Agassiz Fuertes. We thank Mr. Fuertes for the special pains he has taken in executing these drawings.

Color terms used in our descriptions are taken from Ridgway's Color Standards and Color Nomenclature (1912).

Information used by us from published sources is credited through the system of author, year and page references to the list of "Literature Cited" which appears at the end of this paper. The authority for important information obtained from field notebooks or from letters is given in parenthesis together with the abbreviation for the word manuscript- "MS."

Joseph GRINNELL. JosepH Dixon.

September 13, 1918. 


\section{KEY TO THE GROUND SQUIRRELS OF CALIFORNIA.}

1. Size large: body alone more than 9 inches $(228 \mathrm{~mm}$.) long; tail more than 6 inches

(152 $\mathrm{mm}$.), not counting hairs; ears tall and rather pointed; tail bushy.

2. A blackish brown wedge-shaped patch on middle of back between shoulders

2 . No blackish patch on back.

3. Tail longer: without hairs, about 8 inches (203 $\mathrm{mm}$.); no sharply defined triangular whitish patch on each shoulder._._._._. Rock Squirrel (p. 58).

3'. Tail shorter: without hairs, $7 \frac{1}{2}$ inches $(190 \mathrm{~mm}$.) or less; a more or less sharply defined triangular whitish patch on each shoulder.

4. Size larger: body alone more than $10 \frac{3}{4}$ inches $(273 \mathrm{~mm}$.) long; general tone of coloration darker..._-_Catalina Island Ground Squirrel (p. 49).

4'. Size smaller: body alone less than $10 \frac{3}{4}$ inches $(273 \mathrm{~mm}$.); general tone of coloration lighter.

5. Coloration pale in general tone, near light cinnamon-drab; shoulder patches clear silvery white and more extensive

Fisher Ground Squirrel (p. 44).

5'. Coloration somewhat darker, near wood brown; shoulder patches duller white and less extensive---California Ground Squlrrel (p. 9).

1'. Size medium or small: body alone less than 9 inches $(228 \mathrm{~mm}$.); tail less than 6 inches $(152 \mathrm{~mm}$.), not bushy; ears low and rounded, or else reduced to mere rims.

6. Body with conspicuous lengthwise stripes; coloration varied.

7. One white stripe on each side of body; under side of tail conspicuously white; head not more or less yellowish or coppery.

8. Smaller: body alone 6 inches $(152 \mathrm{~mm}$.) or less; general coloration grayish drab..._._._._._._. Desert Antelope Ground Squirrel (p. 94).

8'. Larger: body alone $6 \frac{1}{4}$ inches $(158 \mathrm{~mm}$.) or more; general coloration light clay color.

9. Size slightly greater; tone of color slightly darker, more deeply clay color-.......... Nelson Antelope Ground Squirrel (p. 103)

9'. Size slightly less; tone of color slightly paler, more buffy

Los Baños Antelope Ground Squirrel (p. 110).

7'. Three stripes on each side of body, one white and two black; head more or less yellowish or coppery.

10. Tail longer: without hairs, about $3 \frac{1}{2}$ inches $(89 \mathrm{~mm}$.).

11. Tone of coloration lighter; middle of back more of an ashy brown Inyo Golden-mantled Ground Squirrel (p. 89).

11'. Tone of coloration darker; middle of back more of a cinnamonbrown_-__._-_._Sierra Golden-mantled Ground Squirrel (p. 83)

10'. Taik shorter: without hairs, about $3 \frac{1}{s}$ inches $(79 \mathrm{~mm}$.)..--1 San Bernardino Golden-mantled Ground Squirrel (p. 92$)$.

6'. Body without any stripes: general coloration nearly or quite uniform.

12. Size larger: body alone more than 7 inches $(178 \mathrm{~mm}$.).

13. Larger: body about $\delta_{\frac{1}{2}}$ inches $(216 \mathrm{~mm}$.); middle of back not bright reddish-brown, but grayish-brown_._Oregon Ground Squirrel (p. 59).

13'. Smaller: body about $7 \frac{4}{5}$ inches $(198 \mathrm{~mm}$.$) ; middle of back bright$ reddish-brown....

12'. Size smaller: body alone less than 7 inches $(178 \mathrm{~mm}$.).

14. Tail round and relatively long: over 3 inches $(76 \mathrm{~mm}$.).

15. Tone of coloration paler, light pinkish-cinnamon Yuma Round-tailed Ground Squirrel (p. 76).

15'. Tone of coloration darker, wood brown. - Death Valley Round-tailed Ground Squirrel (p. 80).

15". Tone of coloration medium, grayish-brown or avellaneous Palm Springs Round-tailed Ground Squirrel (p. 81)

14'. 'Tail flat-haired and relatively short: under 3 inches $(76 \mathrm{~mm}$.).

16. Under side of tail pinkish-buff; rim of ear distinct though low Stephens Soft-haired Ground Squirrel (p. 73)

16'. Under side of tail white; rim of ear scarcely discernible above general surface of head_..._._. Mohave Ground Squirrel (p. 75).

Note.-Figures indicating page numbers refer to folios at foot of pages. 



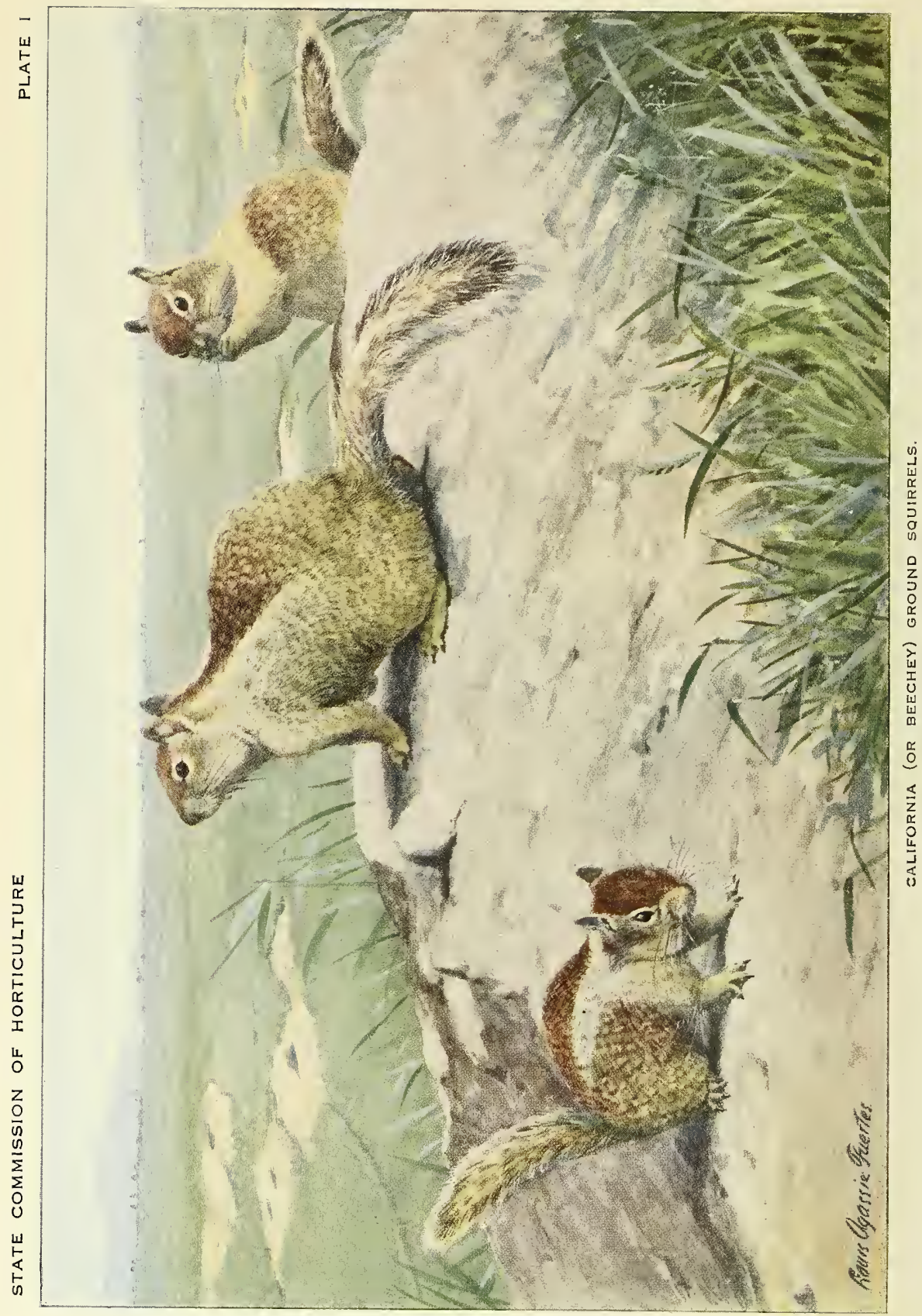




\section{CALIFORNIA GROUND SQUIRREL.}

\section{Citellus beecheyi beecheyi (Richardson).}

\section{PLATE I.}

Other names.-Digger Squirrel, part; Beechey Ground Squirrel ; Beechey's Marmot; Beechey Spermophile; Spermophilus beecheyi, part; Arctomys beecheyi; Spermophilus grammurus beecheyi, part; Citellus variegatus beecheyi; Citellus grammurus beecheyi; Otospermophilus beecheyi.

Field characters.-A large ground-dwelling squirrel, with long bushy tail, goodsized ears, and general brownish coloration; dull whitish area on side of neck and shoulder, and fine dappled pattern of coloration on back and sides, to be seen in close view. Length of body alone about $10 \frac{1}{2}$ inches, with tail (without hairs) about $6 \frac{1}{2}$ inches more.

Description.-Adults in summer pelage: Top of head, stripe down middle of hind neck, whole back, sides, and rump, of a general wood brown tone of coloration, but variegated in fine pattern on back, rump and sides by mottlings of snuff brown and buffy white; these mottlings usually line up in transverse rows, the rows being most distinct across the rump; a large area centering on side of neck and involving

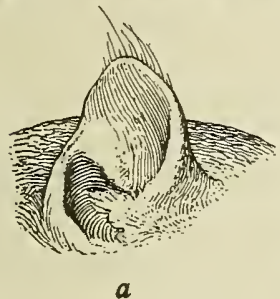

$a$

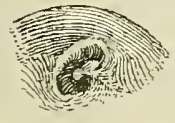

e
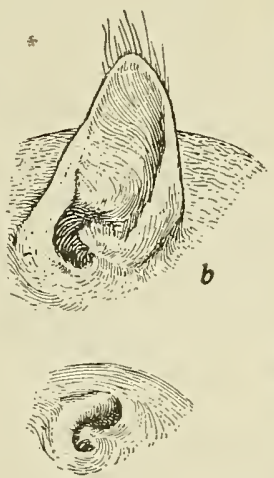

$f$

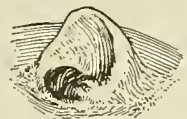

$c$
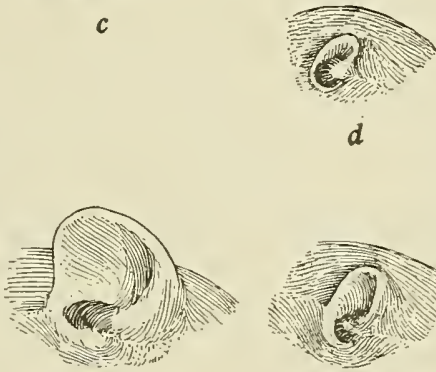

$g$

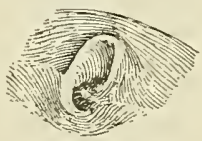

$h$

FIG. 1. Ears of ground squirreIs to show characters of size and shape in different species. $a$, California Ground Squirrel: $b$, Fisher Ground Squirrel; $c$, Oregon Ground Squirrel ; $d$, Stephens Soft-haired Ground Squirrel ; $e$, Mohave Ground Squirrel; $f$, Yuma Round-tailed Ground Squirrel ; $g$, Sierra Golden-mantled Ground Squirrel: $h$, Desert Antelope Ground Squirrel. All natural size and drawn direct from specimens. Note: $a$ and $b$ are extreme examples; the average difference existing between the California and the Fisher ground squirrels is much less; individuals of each race can be found which will overlap some individuals of the other in size and shape.

shoulder, and a faint stripe backward a short distance from upper margin of this area, dull white. Cheeks dirty white, changing to wood brown color between eye and ear; eyelids white; whiskers black. Ears tall and conspicuous, finely haired; color of ear inside, pale pinkish buff; back of ear, front half, black, becomiug dull cinnamon buff at base and on hinder margin; fine black hairs extending above rim at tip of ear sometimes so numerous and long as to form a small tuft; whole lower surface of body, inner sides of fore and hind legs, and upper sides of feet, pinkish buff; hairs of breast and belly gray at base, this resulting in a darker tone on this area. Palms of fore feet naked; soles of hind feet thinly haired behind tubercles, or else wholly nakeâ, due apparently to wearing away of the hairs altogether; claws brownish black, horn-color toward tips. Tail bushy, though not nearly so much so as in the tree squirrels, flat haired, parallel-sided, and square or round ended; hair's along sides of tail

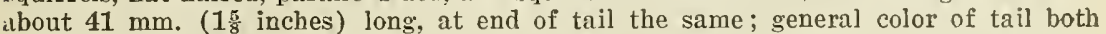
above and below buffy grizzled gray, in other words mixed black and buffy white in 
fine pattern; the buff tone is deeper below than above; close inspection shows the hairing of the tail to be concentrically banded, three black bauds and four light ones, the outermost black band being broadest, and the outermost light one constituting a peripheral whitish fringe.

Color variations.-As far as we cau see, the two sexes are identical in coloration, save as caused by the greater rate of wear to which the pelage of the female is subject during the season when the young are being reared. Wear progresses in some cases until most of the colored ends of the hairs are gone, and a dingy light brown color is acquired, including also the tail. Molting begins anteriorly and prosresses backward.

The material we have studied seems to show but one decided molt in adults each year, and this takes place during July and August. Young, however, seem to undergo two molts in the first six months of their lives. When one-third grown their pelage is characterized by a fluffy texture aud a yellowish tone of color, but the general pattern is closely similar to that of adults; when nearly full grown the young are smooth-coated and show rather brighter tones of brown and clearer white shoulder patches that eveu fresh-pelaged adults.

There are not infrequent special, or "sport" variations, in the Beechey Ground Squirrel, such as albinos, either complete or partial, which have been reported from time to time. We have been told of "black" ground squirrels; and there is in the Museum of Vertebrate Zoology an adult male, from Stanislaus County, taken by W. C. Jacobsen, January 30, 1918, which is of a curious light pinkish-buff tone of coloration, save for the outermost concentric black band on the tail and for the whitish shoulder patches and a suggestion of dappling on the back.

The color description given above was taken from specimens from the vicinity of San Francisco Bay. Specimens from other parts of the general range of the Beechey Ground Squirrel depart frum this slightly in different respects. 'Two specimens at hand from Marysville Buttes, Sutter County, are of paler, grayer toue of general color. A series of skins from the western slope of the central Sierra Nevada averages whiter underneath and darker brown on middle of back. Examples from the southern San Joaquin Valley are paler in tone of coloration and exhibit whiter shoulder patches, thus evidently constituting intergrades towards the Fisher Ground Squirrel. A series from the coast district of southern California, from Santa Barbara to San Diego, shows darker brown back, but whiter under surface of body, and the white shoulder patches are more conspicuously contrasted. Some San Diego County examples in rather worn pelage show a curious reddish tinge on the rump.

Measurements. ${ }^{1}$ - Average and extreme measulements, in millimeters, of twenty full-grown specimens from west-central California are as follows: Ten males: tota] length, 435 (405-475) ; tail vertebræ, 164 (150-175); hind foot, 57 (52-60); ear from crown, 20.5 (17-24); greatest length of skull, 59.1 (56.9-61.1); zygomatic breadth, 36.9 (35.0-39.2) ; interorbital width, 14.1 (13.3-15.0). Ten females: total length, $423(400-460)$; tail vertebræ, 162 (150-175); hind foot, 57 (55-58); ear from crown, $18.4(16-20)$; greatest length of skull, 56.2 (53.S-59.5); zygomatic breadth, $35.8(34.3-37.6)$; interorbital width, 13.9 (13.0-14.7).

It will be seen from the above figures that females are decidedly smaller bodied than males though in tail length they are about the same. The skulls of the oldest individuals, particularly males, show greatest general size, greatest zygomatic breadth (as

${ }^{1}$ The measurements given throughout the present paper have been taken according to the following methods. The external dimensions are those recorded on the label attached to the skin and were taken from the freshly killed animal by the collector in each case. Total length is the distance from the tip of the nose to the tip of the last vertebra of the tail (which is also practically the tip of the tail without the hairs), the body and tail being straightened out but not stretched; tail vertebra is the length of the tail alone (again without hairs), from a point on upper side at base where tail can be bent at right angles to back, to tip of last vertebra; hind foot is measured when extended flat at right angles to leg, from heel to tip of longest claw; ear from crown is the distance vertically from top of head at inner base of ear to extreme tip of ear, not including hairs. The cranial measurements were all taken by the senior author, with parallel calipers reading to tenths of millimeters, from cleaned skulls. Greatest length of skull is taken parallel to axis of skull from anterfor tips of nasals to most posterior point or points on skull (this in some skulls falls on the condyles, in some on the lambdoidal ridge); zygomatic width is the greatest width of skull at right angles to axis, from the outer surface of one zygomatic arch to the outer surface of the other; interorbital width is the least distance between the eye-sockets, but not counting the little notch usually present in ground squirrels on each edge of the interorbital portion of the roof of the skull. 
compared with total length of skull), broadest jugals, stoutest postorbital processes, lighest developed sagittal crest, most nearly approaching parietal ridges (these meeting also farthest forward), and broadest frontal region (which also shows a concave or "dished" upper surface). In other" words, old animals have skulls which are more massive and angular than those of young ones. We find that relative age of an individual can be recognized approximately by the relative degree of development of the above characters. Amount of wear on the crowns of the molariform teeth and of advance in coalescence of the contiguous bones along certain sutures also give criteria for determination of age.

Weights.-Average and extreme weights, in grams, of twenty full-grown specimeus from west-central California are as follows: Ten males, 696 (600-923); ten

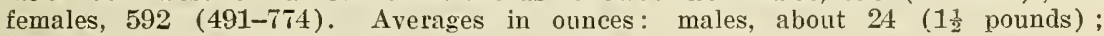
females, about 20 ( $1 \frac{1}{4}$ pounds).

It appears that males are 17 per cent heavier than females. The heaviest specimen out of a total of 36 weighed, was an old male tipping the scales at 923 grams, or $32 \frac{1}{2}$ ounces, or a trifle over two pounds. This auimal was shot June 12 , 1918, in a slaughter yard at Mendota, and was exceedingly fat.

Type locality.- "Neighborhood of San Francisco and Monterey" (Richardson, 1829 , p. 170).

Distribution area.-The greater part of central and southern California west of the desert divides. Altitudinally, ranges from sea-level up regularly to about 6,000 feet, and local!y and sparsely to as high as 8,200 feet (in Yosemite National Park). As regards life-zone, the California Ground Squirrel is most abundant in the Upper Sonoran zone, less so in the Lower Sonoran and Transition, and but relatively rare and local in Canadian (see fig. 23).

More in detail, this squirrel is limited to the northward in the coast belt abruptly at the south sides of the Golden Gate. San Francisco Bay, Carquinez Strait, and Suisun Bay. Its range extends northward over the easteru half of the Sacrameuto Valley to the Marysville Buttes and its limits thence swing northeastwardly through the Feather River country to the southern border of Lassen County. From this last point south it covers both slopes of the Sierras nearly to the Yosemite region, but thence south to Tulare County, only the western slope. In the vicinity of Lake Tahoe it gets a little way into the state of Nevada. To the southward it covers most of the San Joaquin Valley, and the coast belt south throughout the San Diegan district to the Mexican border, and beyond this even to the San Pedro Martil. mountains.

Along the eastern border of its range, from Tulare County south to Riverside County, the race beecheyi grades into the race fisheri. The dotted line on the map (fig. 17) marks approximately the center of the area of intergradation between the two races. As will be seen, the limits of beecheyi swing west across the southern San Joaquin Valley and thence around south so as to exclude the Bakersfield region and the Tehachapi, Tejon, San Bernardino and San Jacinto mountains.

Specimens examined.-A total of 149 specimens from the following localities in California: San Francisco County: Ingleside Race-track, 1. Alameda County: vicinity of Berkeley, 9. Contra Costa County: Walnut Creek, 12 ; west side Mount Diablo, 2. San Mateo County: Sierra Morena, 1; Pescadero Creek, 1. Santa Clara County: Palo Alto, 1. San Benito County: Cook, 2. Monterey County: Monterey, 6. Sutter County: Marysville Buttes, 2. Stanislaus County: Claribell Station, 1. San Joaquin County: eight miles southwest of Tracy, 1. Sierra County: near Sierraville, 1. Placer County: Dutch Flat, 1; Blue Canyon, 1; Cisco, 2. El Dorado County: Fallen Leaf Lake, 1; Kyburz Station, 2. Tuolumne County: Aspen Valley, 6,400 ft., 1. Mariposa County: Merced Grove, 1; Crane Flat, 6,800 ft., 1; Indian Creek, 6,100 ft., 1; Yosemite Valley, 3; Merced Lake, 7,500 ft., 2; Mono Meadow, 7,300 ft., 1; Chinquapin, 6,200 ft., 1; El Portal, 2,000 ft., 2; Coulterville, 2; Pleasant Valley, 1. Merced County: Snelling, 1; Los Baños, 1. Madera County: Raymond, 2. Fresno County: Meudota, 4; Panoche Creek, at 502 ft., 1 ; Friant, 1 ; Kings River, 5,000 ft., 2. Ventura County : Matilija, 4; Ventura, 3. Los Angeles County: vicinity of Pasadena, 7 ; near Azusa, 2. San Bernardino County : near Colton, 4. Riverside County : Thomas Mountain, 6,800 It., 1. San Diego County: Warner Pass, 3; Grapevine Spring, 1; Witch Creek, 8; Julian, 8; Cuyamaca Mountains, 4; San Diego, 2; Point Loma, 10; Chula Vista, 3 ; near mouth Tiajuana River, 1; Dulzura, 7; Campo, 1; Jacumba, 1; Mounta'n Spring, 4. 
The California Ground Squirrel is probably known by sight to more people than any other one of our four hundred kinds of native mammals. It inhabits open ground in well-settled territory and it forages abroad during the daylight hours when its movements are most likely to attract attention. Numbers are to be seen from the windows of passing trains, and the traveller by automobile is often thrilled by the narrow escapes of those heedless individuals which dash across the road immediately in advance of him, not infrequently to their own undoing. Then, too, this squirrel has, perhaps, been more widely advertised than any of our other mammals. A few years ago it came into prominence as a proven disseminator of the dreaded bubonic plague, and it has become notorious for its exceeding destructiveness to cultivated crops.

The term "Digger Squirrel" is often applied to this species, more especially in the foothill and mountain regions, in recognition of its burrowing habits, to distinguish it from the tree-inhabiting gray and red squirrels. The book name, Beechey Ground Squirrel, much used in the literature relating to it, is derived from the accepted scientific name Citellus beecheyi. This name, beecheyi, was bestowed upon the animal by its original describer (Richardson, 1829, p. 170) "in honour of the able and scientific Commander of the Blossom," Captain F. W. Beechey. The British ship "Blossom" cruised the Pacific Ocean northward even to Bering Strait during the years 1825 to 1828. Collections of specimens were brought back from many localities visited, including San Francisco and Monterey; among these specimens was one or more of the squirrels in question. These were evidently preserved for the most part by Mr. Collie, surgeon of the ship, who is quoted by Richardson as stating that "this kind of Spermophile "burrows in great numbers in the sandy declivities and dry plains in the neighbourhood of San Francisco and Monterey, in California, close to the houses. They frequently stand up on their hind leg's when looking round about them. In running, they carry the tail generally straight out, but when passing over any little inequality, it is raised, as if to prevent it being soiled. In rainy weather, and when the fields are wet and dirty, they come out but little above ground.'" And further information is given, according, for the most part, with what anyone can see for himself today in the same general region. This attests to the acuteness of observation of Mr. Collie, and also shows how the squirrels had already, some ninety years ago, begun to impress people with their numbers and boldness.

The California Ground Squirrel may be distinguished from other members of the squirrel family by the combination in it of the following characters: essentially ground-dwelling habits, relatively large size, long bushy tail, tall pointed ear's, and generally grayish coloration with a three-cornered silvery white patch on each shoulder. Close inspection discloses a finely dappled pattern of coloration (see Fig. 2 ) such as is not shown in any tree squirrel or in any of our other ground squirrels except its near relatives, the Douglas, Fisher, Rock and Catalina Island squirrels. The detailed descriptions, measurements, etc., as given in the accompanying small-type paragraphs, should be studied for further particular's in this connection. 


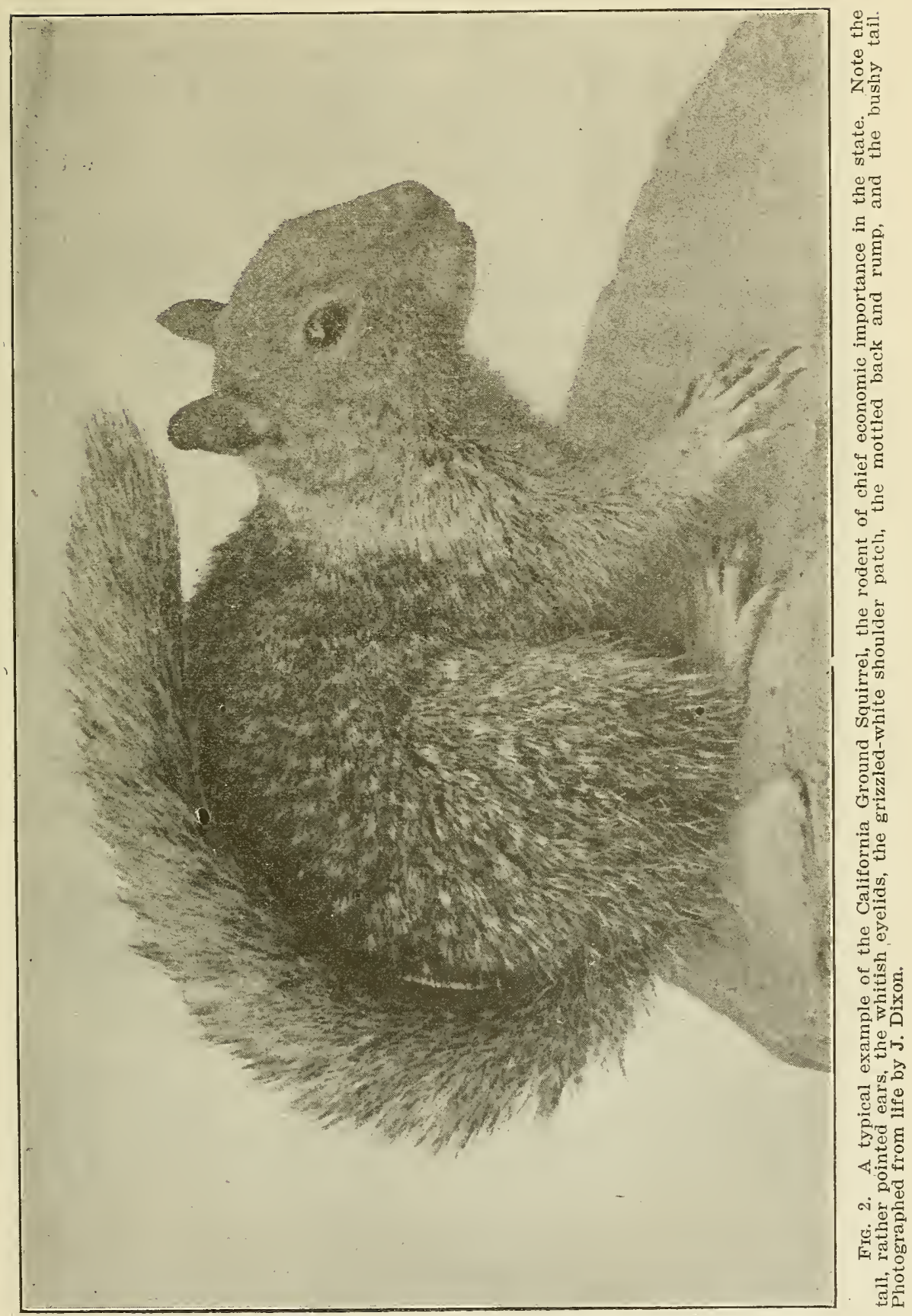


The species now under discussion is restricted in its distribution mainly to the state of California. It extends a little ways south intn Lower California; and to the eastward it barely crosses the Nevada line in the vicinity of Lake Tahoe. To the northward in the coast belt it is cut off sharply by the Golden Gate and San Francisco Bay, but in the interior it extends to the headwaters of the Feather River. Southeastwardly toward the deserts the race beecheyi blends into the race fisheri, which in turn is wholly cut off by the hottest deserts beyond. (See map, fig. 17.) In the coast belt north of San Francisco Bay and from the upper Sacramento Valley northward the Beechey Squirrel is replaced by the Douglas Ground Squirrel.

Altitudinally the California Ground Squirrel ranges from sea level, as on the shores of Monterey Bay, up to an altitude of at least 8200 feet, as in the Yosemite National Park. It is most abundant on the plains of the San Joaquin and in the Coast Ranges and Sierra foothills. As regards life-zone, the metropolis of the species lies in the Lower and Upper Sonoran (see fig. 23). It is less numerous in the yellow pine belt (Transition zone), and is but rarely or sparingly represented in the Canadian zone, still higher on the mountains, Its preferences as to local conditions are not closely limited, except that it avoids dense chaparral and thick woods. It frequents pasture lands, grain fields, orchards, sparsely tree-covered slopes, small mountain meadows, rock outcrops on the tops of ridges, and even granite talus slopes. It is always most abundant, however, in the open situations, and its decided preferences are such that it thickly populates much of the best farming and grazing lands in the state, to the great reduction of their producing value from the human standpoint.

This squirrel secures shelter for itself and young, and safety from its enemies, by burrowing in the ground. Where possible it chooses to excavate its retreats in hillsides or in low earth banks. Here some at least of the necessary digging can be done in a horizontal direction. But, of course, those members of the species which live on the plains or on small flats or meadows in the foothills or mountains must dig down vertically for considerable distances to gain the requisite protection. Many of the squirrels which live in the granite country make their homes under large boulders or in rock taluses where a minimum of burrowing is necessary to insure safe retreats. On wooded hillsides special safety from enemies that dig is secured by location of the burrows under tree-roots or old stumps.

In the foothill region at the southern end of the San Joaquin Valley there seems to be a decided tendency on the part of the ground squirrel to select alluvial fans for home sites. This preference may be accounted for by the fact that the plants upon which the squirrel feeds make a better growth in the deep alluvial soil there than they do on the adjoining hillsides which are often steep and with but shallow cover of soil. For the same reason the alluvial fans afford easier digging to considerable depth and hence better protection. In seven burrows in different localities, in which the squirrels were gassed and then dug out ( $\mathrm{J}$. Dixon, MS), the extent, diameter and depth were found to vary and to depend largely upon the nature of the soil. In shallow adobe or clayey soil, underlaid by broken rock, the burrows were found to be short, of 

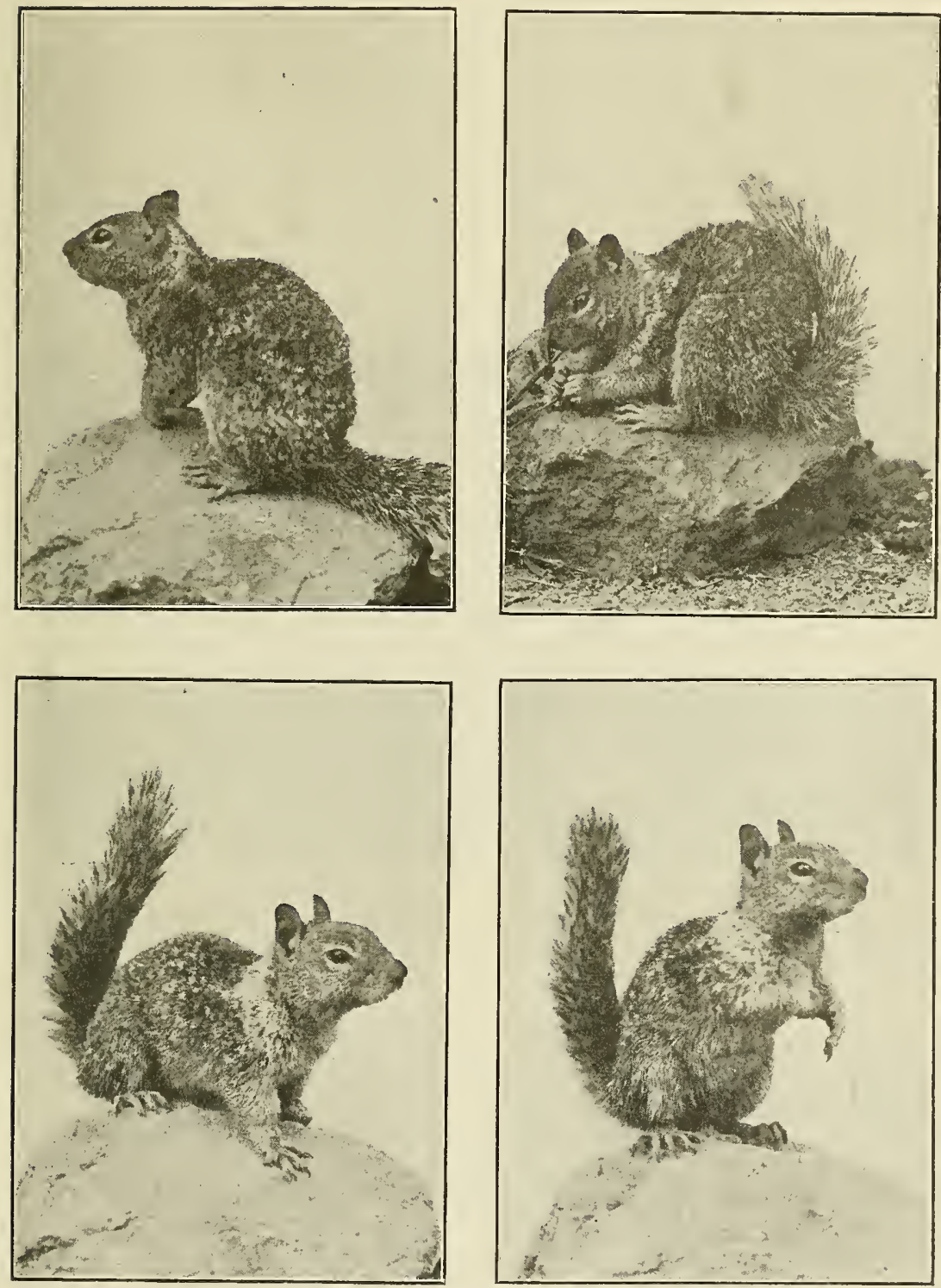

FIG. 3. Four characteristic poses of a California Ground Squirrel. Photographed by J. Dixon at Berkeley in August, 1918. 
small diameter, and not reaching to any considerable depth. Those in alluvial or sandy soil were found to be of large diameter, of greater extent, and to reach to much greater depths.

The most conspicuous signs of activity on the part of ground squirrels in any locality are the large mounds of earth that have accumulated in the course of excavating the burrows. This earth is commonly thrown out in a fan-shaped pile directly in front of, and to the sides of, the main entrance to the burrow (see fig. 4). These mounds of earth are often three or four feet in diameter and from six to ten inches above the general level. They vary greatly in size, but average larger in sandy soil than in clayey or rocky ground. The size of the mound is, however, no reliable index to the length or size of the burrow except in those cases where the burrow is of a straight or simple pattern. In

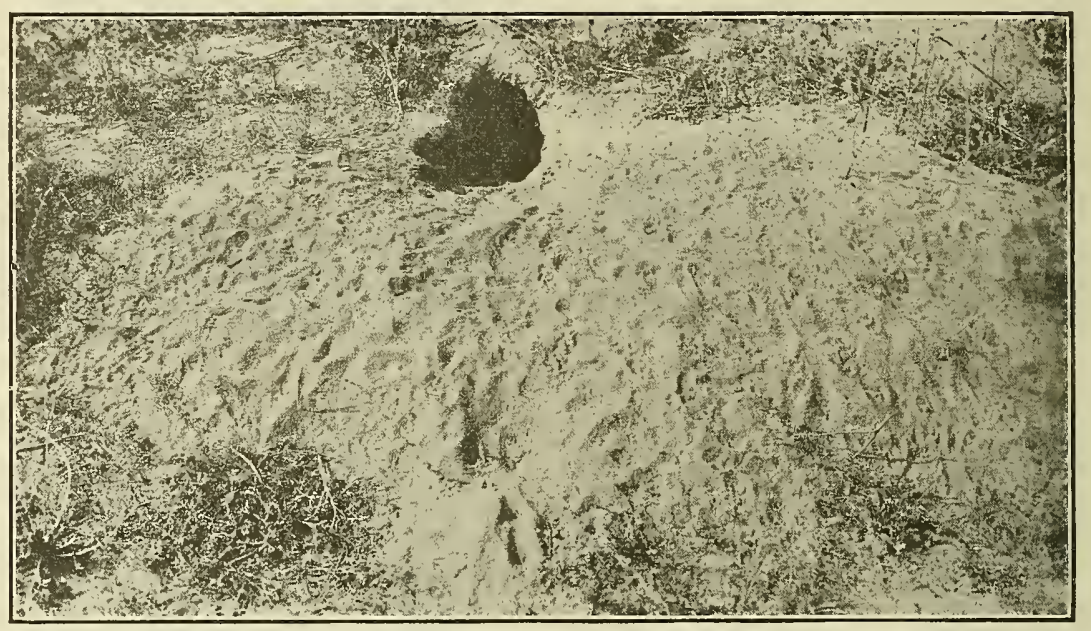

FIG. 4. Mound and burrow entrance of a "digger" squirrel, in sandy ground. Mounds of earth such as these are often three or four feet in diameter and rise from six to ten inches above the general level. The route taken to the feeding grounds being used at this particular time is indicated by the numerous tracks at the left-hand side of the entrance. Photographed at Tipton, Tulare County, May 23, 1918.

colonial or intercommunicating burrows the dirt is not always thrown out at those entrances which allow of the shortest possible "haul."

Most of the work of tunnel excavation is carried on during the spring months, as is shown by the mounds of fresh, soft earth aceumulated at the mouths of the burrows in that season. In the lowlands, where there is a large crop of wild oats in the springtime, this newly excavated earth supports a ranker growth than the surrounding parts of the field, so that, as one of our party wrote in his field notes, "the plain looks like a cemetery overgrown with grass," with these taller stands of oats about the squirrel holes suggesting grave mounds.

To some extent the ground squirrels, like the pocket gophers, thus act on wild land as natural cultivators of the soil, and may thus serve a useful purpose. On the other hand, their burrows are frequently the cause of much destructive erosion on hillsides during heavy rainstorms. Numerous small landslides have been noted on steep hillsides 
on the campus at Berkeley, that were plainly caused by the presence of squirrel burrows which had concentrated and conducted the water in narrow channels instead of permitting it to spread out and soak in or run off in the natural way. The presence of squirrels along irrigation canals results in the embankments becoming undermined by their burrows, with ensuing disastrous breaks in the canals, especially at times of high water.

Digger Squirrels are firm believers in the daylight saving plan. Their activities above ground are restricted to the hours between sunrise and sunset. They love the warm sunshine and may often be seen sprawled upon the summits of stumps, rocks or other points which afford safety as well, basking in the morning or later afternoon sunshine. During spring and summer they come out of their burrows soon after sun-up. They are at those seasons most active during the middle of the forenoon and again during the late afternoon, but avoid the intensest heat of midday. During midwinter those squirrels which do not remain underground altogether make their appearance only late in the forenoon of bright sunny days. Light and warmth seem to be essential to their successful existence aboveground.

The observer afield often comes upon ground squirrels which are some distance from their holes. Such animals usually run, with bodies and tails undulating and closely paralleling the ground, to the near vicinity of their burrows, where they then post themselves in upright position. They can then watch the intruder, yet be in readiness to dart down into their holes at an instant's warning. While thus on watch a squirrel is wont to repeat, at regular intervals of from two to five seconds, its characteristic "bark." This note is really a double one, and may be indicated by the syllables, clink-sup. The second syllable, however, is not audible for any great distance, while the first is loud, staccato, and of decided metallic quality, ealling to mind the sound produced by the blow of a light hammer on an anvil. The impression is enhanced by the regularity and frequency of its utterance, and this will be kept up five minutes at a time. Sometimes, when a squirrel is startled, it gives a more prolonged note, clink-sup-sup-supsup, the last syllables running together as a sort of chuckle. In any event, it is the clink which is the metallic syllable, and which one hears a long ways, more or less mellowed by distance.

If closely pressed the squirrels drop down at once into the protection of their subterranean retreats. Ordinarily when thus frightened down they do not reappear at the surface of the ground for some minutes, five to twenty-five minutes in tested cases, as if to give the suspected enemy a chance to tire of his waiting and depart. Occasionally, when surprised at a distance from its burrow, a squirrel will crouch motionless, it may be almost at the feet of the observer, as if to escape detection by the "freezing" ruse. Extreme fear also on occasion may be part of the basis for this mode of behavior.

In some respects the California Ground Squirrel is much "wiser" than is generally supposed. This has been forcibly impressed upon the junior author during his endeavors to secure photographs. Living squirrels were then observed at close range in their various activities under natural conditions. Several species of chipmunk, as well as the Golden-mantled Ground Squirrel and the Nelson Antelope Ground 
Squirrel, encountered under the same circumstances, soon became accustomed to the camera so that the photographer, himself at some little distance, was able to release the shutter when the lens of the camera was less than thirty inches from the animal photographed. Compared with this, the Digger Squirrels proved exceedingly wary, refusing to show more than their heads even though the camera was disguised and placed six feet distant. The confidence of the Digger Squirrel could no doubt be gained, given sufficient time; but when an approach was attempted by the methods that had proven successful with the other squirrels the results were nil. It looks as though the reactions of the Digger Squirrel had been adjusted to meet that category of enemies which lie in wait at jumping distance.

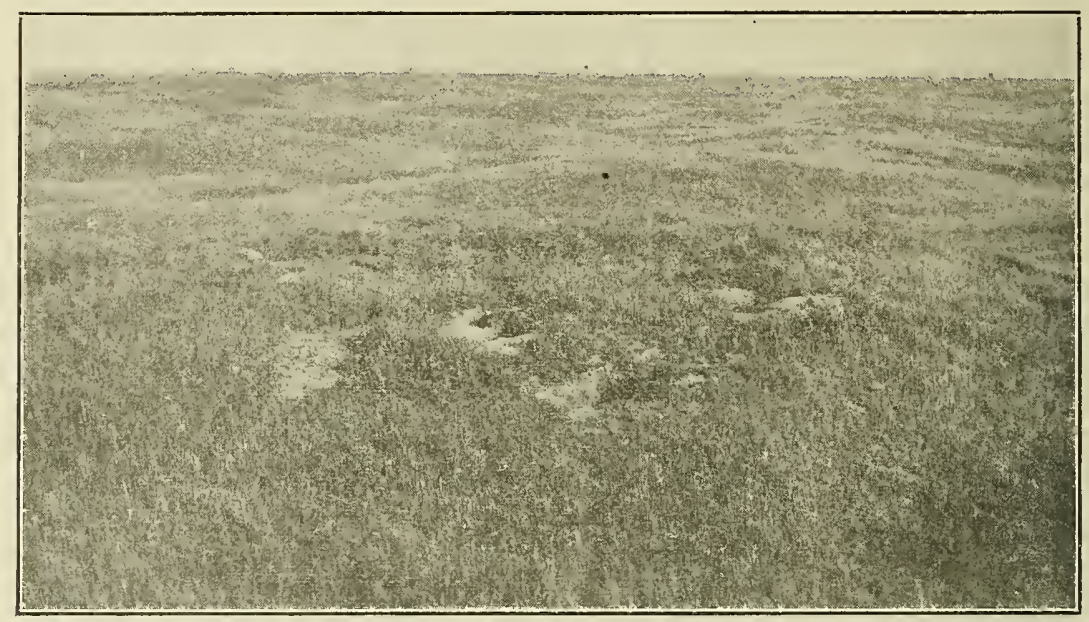

FIG. 5. Typical "hog-wallow" land showing trail and burrows of the California Ground Squirrel. Photographed ten miles north of Fresno, April 10, 1911.

Ground squirrels traveling to and fro, between their holes and their feeding grounds frequently traverse the same courses until regular radiating trails $2 \frac{1}{2}$ or 3 inches wide are worn through the grass (see fig. 5). This is particularly well scen on many hillsides, and on the rolling "hog-wallow" lands along the eastern side of the San Joaquin Valley, where, in the fall, when the grass and weeds are dry, the trails show most distinctly. In the spring, when the new growth is just appearing, the trails are still conspicuous, as the vegetation is slower in starting there than in the adjacent unbeaten tracts. Soon, however, the trails are entirely obliterated, save as the animals renew them hy further use.

In foraging for seed-pods, grain, or fruits, the ground squirrel does not usually eat the food on the spot where it is gathered, but he stuffs it into his capacious cheek pouches (see fig. 13) or else, if it is too large for this, carries it in his mouth nipped between the incisor teeth. He then repairs to some point of vantage such as a rock pile or to the mound at the entrance of the burrow. Here he proceeds to hull and devour the food at leisure and at the same time is near enough to shelter so that he can quickly duck in should an enemy suddenly appear at 
short range. These "husking places" are conspicuously marked by the hulls of seeds and by the rinds and pits of cultivated or wild fruits. Examination of these "kitchen middens" will sometimes give a pretty accurate idea of the character of the squirrels' rations in any locality. A great many of the matured seeds, however, are carried directly below ground to the permanent storehouse.

Droppings, or feces, of the Ground Squirrel are to be observed widely scattered rather than deposited in piles. They may be found about the "husking places" or along the trails or paths which lead from the burrow to the feeding grounds. In the burrows they are accumulated in special places evidently set aside for the purpose. The feces are generally of a cylindrical shape, rounded at the ends, but are quite variable in diameter and volume. In April when green food is abundant fresh feces are of a greenish hue and are often soft and flattened. During the drier portions of the year the droppings are covered with a dark brown coating, while the interior is composed of a dry mass consisting of hulls of weed seeds and finely chopped and shredded vegetable fiber, from 3 to 10 millimeters long. A typical dry dropping measured 16 millimeters ( $\frac{5}{5}$ inch) in length, with a diameter of 6 millimeters ( $\frac{1}{4}$ inch), and weighed $\frac{1}{10}$ of a gram.

The California Ground Squirrels do not dwell in thickly populated "colonies" of sharply restricted extent, as is the case with the prairie dogs of the Middle West. Still there is with our rodent a tendency to occupy certain definite tracts in a general territory to the exclusion of intervening places and this without obvious reason as regards food
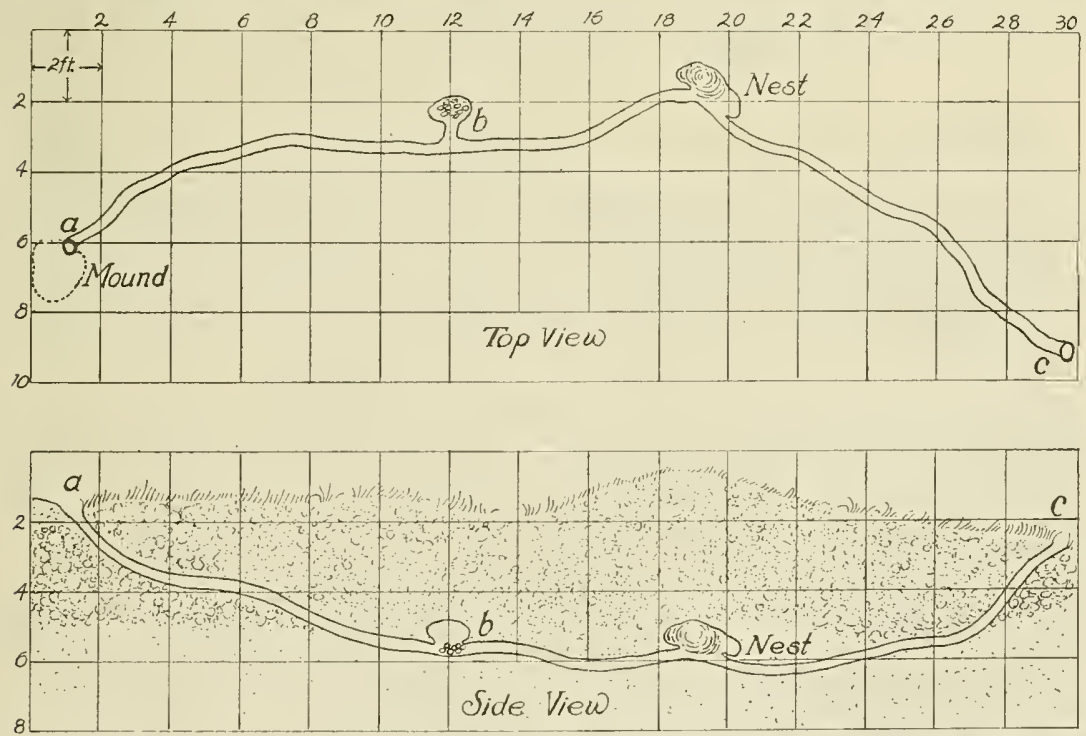

FIG. 6. Plot (plan and elevation) of used burrow of a male "digger" squirrel, as excavated by J. Dixon on an alluvial talus in the foothills near San Emigdio, Kern County, April 28, 1918.

Main entrance at $a$; refuse sump in old nest-cavity at $b$; "blind" exit in thick grass at $c$. Unusual depth of burrow, as shown in profile, was due to thick rock-filled overIying stratum, beneath which the squirrel had found easy digging horizontally after having once penetrated the less resistant part of the layer at the edge of the talus.

Total length of burrow, 34 feet; average diameter, $4 \frac{1}{2}$ inches; greatest depth reached, $5 \frac{1}{2}$ feet; volumetric contents of entire burrow, $4 \frac{4}{5}$ cubic feet. 
supply and kind of soil. It would seem that centers of population may arise through the historical circumstance of original settlement by first-comers. This would be particularly the case in fields newly invaded, where descendants would establish their burrows in the near vicinity of their pioneer parents.

Digging operations were carried on by us during the breeding season of the ground squirrel, in quest of all obtainable facts in regard to their habits underground. Three general types of burrows were encountered. The male squirrels were usually found in short, shallow, simple burrows at the outskirts of the "colony." The burrow belonging to a male herewith illustrated (fig. 6) proved to be longer than usual with males,
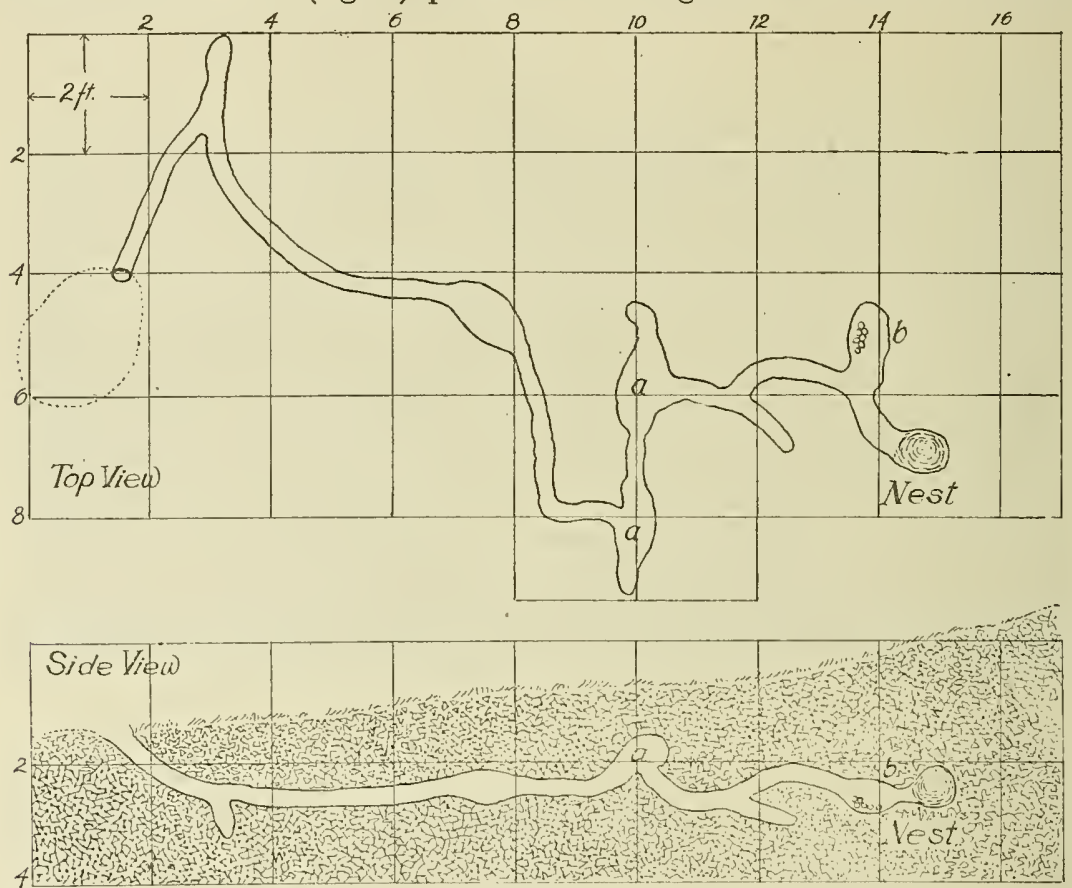

FIG. 7. Plot (plan and elevation) of used nesting burrow of a female "digger" squirrel, as excavated by J. Dixon and G. R. Stewart on a west slope in Strawberry Canyon near Berkeley, April 6, 1918.

Entrance at left; old nest chambers at $a$; refuse sump at $b$; used nest at extreme right, which was found to contain the mother and four small young.

Total length of burrow, 22 feet; average diameter, 43 inches; greatest depth reached, 30 inches; volumetric content, $4 \frac{4}{5}$ cubic feet.

and reached to a greater depth, but its simplicity is characteristic for that sex. We failed to secure a single male squirrel in any burrow found to be occupied by a female with young. It is believed that at least during the breeding season the male squirrels live altogether by themselves in their own individual burrows.

A burrow from which a female and four young with eyes still unopened were secured is shown in fig. 7. It will be seen from this illustration that the nest burrow of the female is relatively complicated. This particular burrow was extremely difficult to follow on account of the many turns and "blind alleys." 
The third type of burrow (see fig. 8) might well be called a "colonial burrow," as it is used by both sexes and also by the young after these leave the nest burrow and begin to forage for themselves. Colonial burrows are used largely as "safety zones." They afford convenient places for the squirrels to duck into when danger unexpectedly appears. These burrows are often from 100 to 200 feet in length and form a communicating system of underground runways connecting from six to twenty entrances or surface openings. The nests in the colonial burrows were old and had the appearance of having been used by many
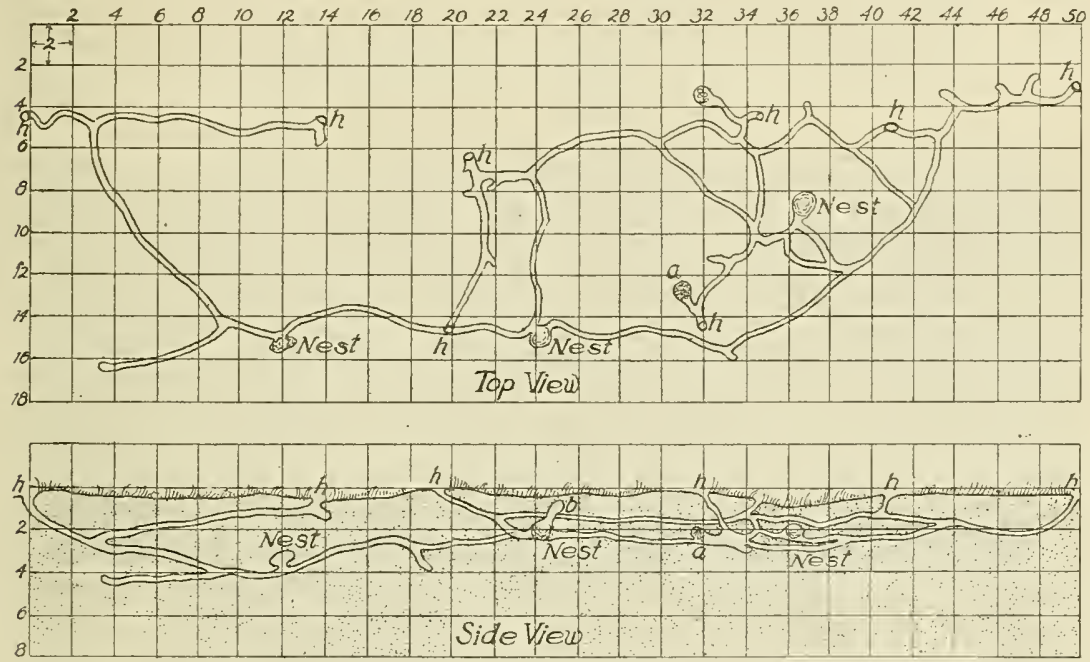

FIG. 8. Plot (plan and elevation) of a "colonial" burrow-system of "digger" squirrel in sandy ground in irrigated section near Bakersfield; excavated by J. Dixon and H. G. White, May 3, 1918 .

Various entrances at $h$; food store at $a$; "back-door" exit for emergency purposes at $b$; nest cavities as indicated.

Total length, 138 feet; average diameter, $4 \frac{3}{2}$ inches; greatest depth reached, 4 feet: volumetric content, 17 咅 cuble feet.

individuals at various times. These colonial burrows were not found to be in any case used as breeding burrows. It is possible that they may have consisted of one-time breeding burrows, now connected or linked together.

The relative extent of any one burrow system is thus dependent not only upon kind of ground-in other words, upon the difficulties encountered in digging - but also upon the estate of the individual or individuals directly concerned. Table I gives data in regard to the three types of burrows. In the seven burrows which were dug out and of which careful record was kept, the shortest occupied burrow was five feet long and the longest 138 feet. The average was 35.2 feet. The average diameter varied from $3 \frac{1}{2}$ to 5 inches, with a mean of 4.3 inches. The cubic air content was found to vary from 1.03 to 17.8 cubic feet, the average being 5.2 cubic feet. 
TABLE I. Data relative to Uurrows of the California Ground Squirrel.

\begin{tabular}{|c|c|c|c|c|c|c|}
\hline $\begin{array}{l}\text { Type of } \\
\text { burrowy }\end{array}$ & Locallty & Date (1918) & $\begin{array}{l}\text { Length of } \\
\text { burrow } \\
\text { (in feet) }\end{array}$ & $\begin{array}{c}\text { Greatest } \\
\text { depth of } \\
\text { burrow } \\
\text { (in inches) }\end{array}$ & $\begin{array}{l}\text { Average } \\
\text { diameter } \\
\text { of burrow } \\
\text { (in inches) }\end{array}$ & $\begin{array}{l}\text { Cubic } \\
\text { content } \\
\text { of burrow } \\
\text { (in cubic } \\
\text { (eet) }\end{array}$ \\
\hline Male & Strawberry Canyon, Berkeley_- & April 3 & 5 & 18 & $3 \frac{1}{2}$ & 1.03 \\
\hline Male & Strawberry Canyon, Berkeley.. & April 4 & 8 & 30 & 4 & 1.40 \\
\hline Male & Strawberry Canyon, Berkeley_- & April 4 & 14 & 30 & $4 \frac{1}{2}$ & 2.40 \\
\hline Male & 12 miles west of Fresno & May $27-2 s$ & 26 & 45 & 5 & 4.6 \\
\hline Female & Strawberry Canyon, Berkeley.- & April 6 & 22 & 30 & $4 \frac{1}{2}$ & 4.8 \\
\hline Male & San Emigdio Creek, Kern Co..- & April 27-28 & 34 & 66 & $4 \frac{1}{2}$ & 4.8 \\
\hline \multirow[t]{2}{*}{ Colonial } & $\begin{array}{l}12 \text { miles south, } 5 \text { miles west of } \\
\text { Bakersfield }\end{array}$ & May 3 & 138 & 48 & $4_{4}^{3}$ & 17.8 \\
\hline & Average & & 35.2 & 38.1 & 4.3 & 5.2 \\
\hline
\end{tabular}

In illustration of the fact of variability in depth and extent of burrow system with nature of soil, some actual instances as revealed by excavation may be described. The layers of alkali hardpan in the Fresno region were found to have a very decided influence on the course of the burrows. In most cases where the hardpan was near the surface, the burrows were found to extend through the hardpan to the soft ground that is often to be found just beneath. No evidence was found to indicate that the squirrel had dug through even thin layers of solid hardpan except at points where natural cracks or openings through it occurred. Slight cracks in the hardpan were sometimes enlarged, this apparently having been done during wet weather, to sufficient size to enable the squirrel, but not such an enemy of the squirrel as a coyote or badger, to readily pass through. In following the various cracks and openings through and between the strata of hardpan, the burrows were found to twist about in very erratic fashion. The sudden elevation in a burrow of sometimes as much as two feet was found to form a very effective barrier to the flow of any gas such as that of carbon bisulphid, which is heavier than air; such a gas would gather into the low places (see Stewart and Burd, 1918).

The deepest burrow system uncovered was situated in an alluvial talus in the foothills near San Emigdio, Kern County. The maintenance of the great depth (from four to five and a half feet for a distance of twenty feet) was clearly due to the squirrel having followed a soft layer at the margin of the talus down to below the level of the four-foot rock-filled surface layer. Beneath this the squirrel had progressed easily through the soft soil as long as he kept beneath the rocks-which he was practically forced to do (see fig. 6).

There seems to be little or no evidence to support the rather widespread notion that ground squirrels burrow down until they reach water. A colony burrow was unearthed in an irrigated section near Bakersficld, where the water level was known to be only five or six feet below the surface of the ground. No part of the burrow (see fig. 8) was found to extend deeper than four feet and hence not down to the water level. While ground squirrels do not absolutely require water, where surface water is to be had they often go considerable distances to secure it, going acloss the country sometimes as far as a quarter of a mile. In many places squirrels are found thriving where it is known that it is over 100 feet to ground water and miles to surface water. 
It is quite likely that California Ground Squirrels construct new burrows from time to time, or, what is more probable, that each young individual as it approaches maturity leaves the parent burrow and digs a home for itself. In any event, in places there are many more burrows than individual squirrels present at any one time. Some of these tunnels, especially in the plains and foothill country, are joined together below ground to a greater or less degree and constitute the colonial burrows already described. When hurriedly seeking safety a squirrel will pitch down into the nearest one of a number of holes in the vicinity of the one about which it was first seen. The commonly uninhabited burrows may thus serve in extremity as temporary refuges.

The burrows of the squirrels are often inhabited by species of animals other than the rightful owners. Ground owls habitually make their homes in squirrel holes, probably deserted ones; and, to a less extent,

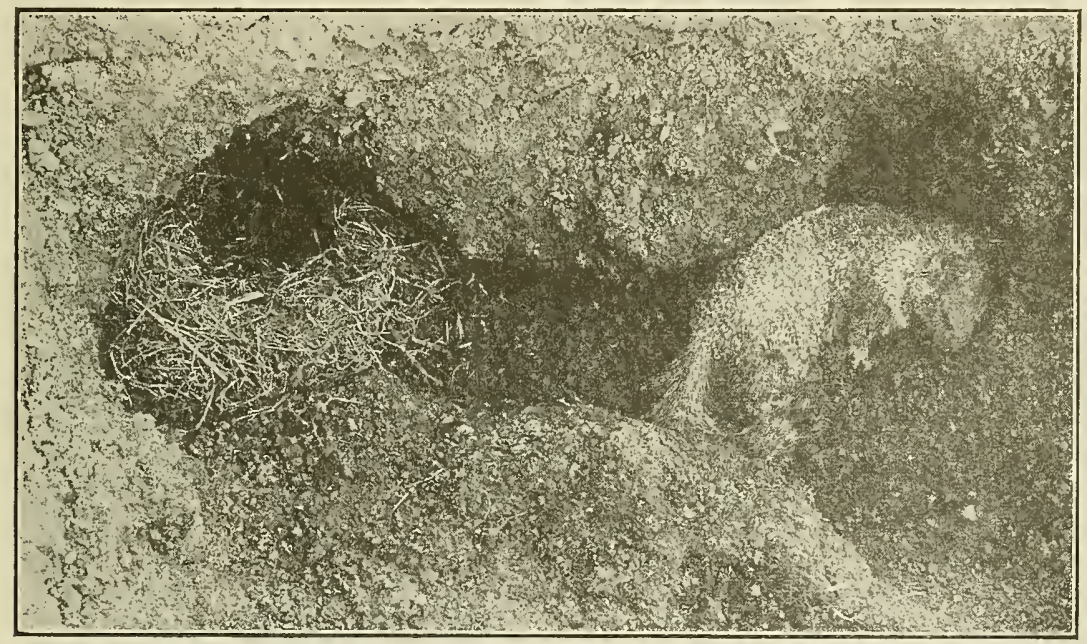

FIG. 9. Nest and male of "digger" squirrel as dug out after burrow was treated with carbon-bisulphid. The spherical shape of the nest-cavity and the structure of the nest itself is well shown.

the holes are frequented by California toads, Western gopher snakes and Pacific rattlesnakes. It is unlikely that the presence of the latter two animals is congenial to the squirrels, as both of these snakes are known to eat ground squirrels in numbers. Regularly communal occupants of squirrel burrows are scorpions, centipedes and mole crickets. Mole crickets were found to serve as reliable indicators of the efficiency of the gas when squirrels were fumigated in their burrows. If the gas had not killed the crickets it was found that the squirrels had not succumbed.

California Ground Squirrels are accustomed to furnish their underground quarters comfortably. Special nests are constructed and main. tained in good order, where the individual may sleep or rest in warmth, free from contact with the damp earth. Each burrow occupied by a single squirrel was found to contain at least one well-made nest. In some cases there were two, one obviously older than the other. In the 
colonial burrow that was dug out, three nests were found, of which two were new. The nests were always placed well back in the burrows (see figs. 6, 7), where they would have maximum protection from digging enemies such as coyotes and badgers. The cavities in which the nests were placed were short globular chambers and were usually situated slightly above and to one side of the main run, so that the drainage was away from rather than into the nest. The cavity in which a nest containing a female and four small young was found measured 10 inches in length, 9 inches wide and 7 inches high. The nest cavity used by a male squirrel was $12 \times 10 \times 7$ inches (in the same dimensional order), while the two nest cavities in the colonial burrow measured $12 \times 10 \times 8$ and $12 \times 12 \times 7$ inches, respectively.

All of the nests found were of similar composition and construction. Finely shredded dry grass blades and roots, and fine stems of foxtail and needlegrass, formed the bulk of the constituent material. The nests were spherical in shape and deeply cupped. The walls were from

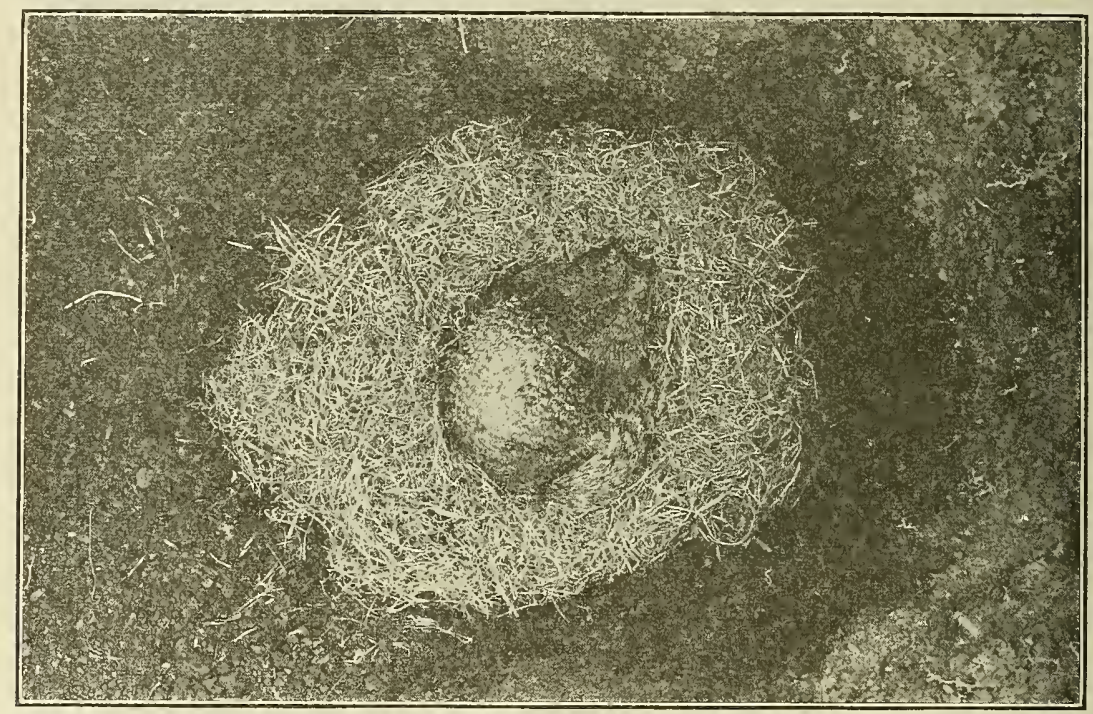

Fig. 10. Nest and female of "digger" squirrel as uncovered after the burrow had been gassed. Excavated on the University of California Campus, Berkeley, April 6,1918 .

two to two and one-half inches thick. The walls of the nest which contained the young squirrels were arched over and met at the top, forming a sort of a canopy. Entrance to this nest was gained through a hole near the top. The material in the walls had been compressed or felted into a thick, warm fabric. The outside dimensions of this nest were $10 \times 9 \times 7$ inches, while the inside cavity measured $6 \times 4 \times 5$ inches. Compared with that of the female just described, the nests of male squirrels were smaller, had lower walls and were more loosely constructed (see fig. 9). The nests of the males did not completely fill the cavities in which they were placed, as did the nest of the female. A nest occupied by a male measured $8 \times 10 \times 7$ inches outside and $4 \times 5 \times 4$ inches inside. The three nests in a colony burrow excavated 
were large and evidently of considerable age, since the foxtail blades and stems composing the nests were old and broken up into short bits. One of these nests measured $12 \times 10 \times 8$ inches outside and $6 \times 5 \times 4$ inches inside, while the other measured $12 \times 12 \times 7$ inches outside and $6 \times 4 \times 5$ inches inside. The third nest was old, being merely a flat mat of trampled down bits of foxtail stems.

The nest of the female (fig. 10) was 30 inches below the surface of the ground. The nest of a male was 28 inches below the surface, while the two used nests in the colony burrow were 20 and 24 inches underground. The female and the male nests were in clay ground and the two colonial in sandy soil. The average depth of nests below the surface of the ground, taking into account all of the nests found, was 30 inches.

Contrary to general belief, we have found ground squirrels to be very cleanly animals about their nests and burrows. No feces (droppings or dung) were found in any nest. Such material was found

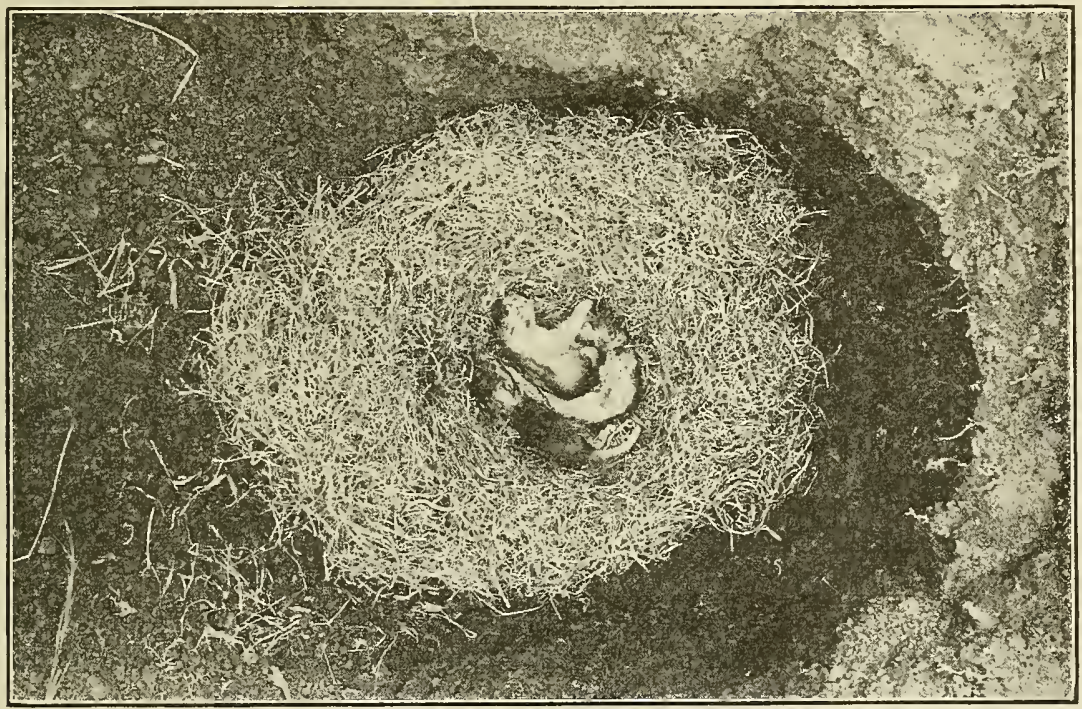

FiG. 11. Nest and small young of "digger" squirrel after removal of the female. Same nest as shown in Fig. 10.

heaped up in piles in special chambers usually just off the main run, but within easy reach, 18 to 24 inches, from the nest. These sumps were lower than the nests and were sometimes nothing but old nest cavities which had been dug somewhat deeper than they had formerly been. In the burrow of a male squirrel, a pile six inches in diameter and two inches high, of feces soggy with urine was found in a sump slightly below and fourteen inches distant from the nest. Female squirrels appear to be more particular in this regard than the males, in that the sump is farther removed from the nest.

The nest that contained the four young squirrels (see fig. 11) was alive with fleas, which swarmed over the helpless young. These fleas persisted in remaining in the nest for three days after the young 
squirrels had been removed. Other nests were found to be infested with fleas, though at least one-half of the nests examined were free from these parasites. In certain localities squirrels were taken that were to casual appearance absolutely free from fleas, while in other localities squirrels taken were invariably infested to a greater or less extent. The species of flea that infests ground squirrels is not the species that commonly attacks human beings. While ground squirrels are their preferred hosts, we found that the former did not object to human society when their squirrel hosts had died. At least two methods are used by the squirrels to rid themselves of these uninvited guests. The first, or dust-bath method, is that of suffocation of the fleas which hide in their fur by thorough wallowing in especially dusty places. The second is by digging a new burrow and making a new nest, thereby leaving the bulk of the fleas behind.

Some years ago it was discovered that the fleas harbored by the California Ground Squirrel carried the bacillus of bubonic plague. A vigorous carnpaign of extermination was waged against the squirrels by the United States Public Health Service and they were practically eliminated from many areas, locally, in the San Francisco Bay region.

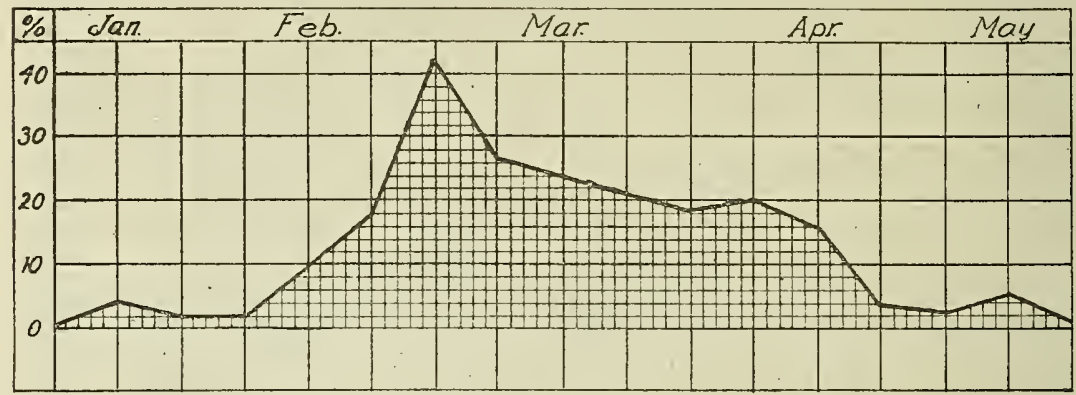

F'IG. 12. Diagram showing extent and height of breeding season in the California Ground Squirrel. Heavy line shows percentage of females pregnant, for weekly periods from January to May. Based on record of embryos found in over 10,000 females examined by the United States Public Health Service (McCoy, 1912, p. 1070).

Soon after the efforts against the squirrels were relaxed the latter began to "spill in" from adjacent areas until now in places they are as numerous as ever. Nevertheless the prime object was attained, that of eliminating the foci of dissemination of the disease.

It is extremely important to know definitely the season and rate of breeding of any economically important rodent. Fortunately for our purpose, there is available for the California Ground Squirrel abundant data, supplied through the records of the United States Public Health Service (see McCoy, 1912, p. 1070). As will be seen from the accompanying diagram (fig. 12) based on over 10,000 females examined, the breeding season is restricted to a comparatively brief period of the year. Pregnant female ground squirrels have been taken in the Bay region as early as the first week in January, but the main breeding season does not begin until February, and it is practically concluded by the middle of April. The largest per cent of pregnant females is to be found during the last week in February. By Jume 4 only two-tenths of one per cent (0.2) of females examined contained embryos. At higher 
altitudes, where warm weather comes on much later and more abruptly, these breeding dates would be correspondingly later and the breeding season still more restricted.

While males and females occur in practically equal numbers, mating seems to be promiscuous; there is no permanent pairing off.

The number of young per litter, as ascertained from counts of embryos, varies from 4 to 11 . The average, from very extensive records kept by the United States Public Health Service (McCoy, 1912, p. 1070), may be inferred to be very close to 7.2. The same records serve further to show that there is some variation in size of litter from montli to month. The average for February is 6.9 ; for March, 7.3; for April, 7.5; for May, 6.8. The tendeney seems to be toward slightly larger litters in April, which is beyond the date of maximum number of pregnant females (see fig. 12). Number of mammæ (nipples), which is usually six pairs in this species, occasionally but five, is no criterion for number of young per litter. All the evidence at hand indicates that each female raises but one litter each year. A female ground squirrel was taken on the University campus at Berkeley, on March 13, 1918, which contained eleven embryos each of which measured three-fourths of an inch long. Eight of these were contained in one branch of the uterus and three in the other. Another female taken at the same time contained eight embryos, each of which measured five-eighths of an inch long. Five of these were in one branch of the uterus and three in the other.

On April 6, 1918, G. R. Stewart and the junior author dug out two female ground squirrels which had been previously gassed in their burrows. One of these females was found in a nest with four small young which we took to be about ten days old, since their eyes were not yet open. These baby squirrels averaged 170 millimeters or $6 \frac{3}{4}$ inches in length; a typical one weighed 61 grams, or a little over 2 ounces. They were well covered with hair, which already showed on the back the characteristic dappled pattern of the adult squirrel. The tail, however, was nearly round and showed little sign of the fringe of hairs along the sides. Their stomach contents showed no sign of their having eaten green vegetation or anything else than milk. Data from other sources indicate that the young are not completely weaned until they are at least half grown. The other female secured in an adjoining burrow not over ten feet distant was found to contain seven small embryos each of which measured three-eighths of an inch in length. These embryos could not well have reached full development short of two or three weeks, so we have a variation of nearly a month in time of birth at one locality.

Cases such as those just given are thought to be exceptional and may serve in part to explain the occurrence of late litters such as have been the basis of the claim that this animal has two litters a season. Litters of young squirrels which sometimes appear very late in the season are, too, likely to be merely the result of efforts to replace first litters of young which have met an untimely death. Thus two litters might be born in one season, though only one raised.

Shaw (1916, p. 4) gives 24 or 25 days as the period of gestation in the Columbian Ground Squirrel (Citellus columbianus) in the region about Pullman, Washington. The period of gestation of the California 
Ground Squirrel has not to our knowledge been determined; yet the facts at hand, such as the general rate of development of the embryos, and of the young after birth, lead us to believe that it is close to thirty days.

The bulk of the young ground squirrels in any one locality make their appearance with remarkable uniformity as to size and regularity as to date. Our data is incomplete, as to exact time of birth; but we have plenty of records of embryos in various stages of development, and we can observe the time of appearance of the young squirrels above ground. In the lowlands the majority are probably born the last of March, and by the last of April the first born are beginning to appear aboveground, playing about the mouths of the burrows. In the higher altitudes the young are born later. Females in the Transition Zone and lower part of the Canadian Zone had not yet given birth to their young in June. "Spring" in the lowlands comes in April, while the spring of the higher altitudes does not occur until late June or July. Hence the young do appear at the same season, considering the differences in temperature conditions at the different elevations. The accumulation of a certain quantity of heat from without seems to be necessary each year to start the squirrels breeding.

Young California Ground Squirrels may be considered fairly precocious. They ordinarily begin to venture outside their nest burrows when yet very small, in ascertained cases only cne-fourth or even onefifth the weight of the adults. They are then probably not over four weeks old. At Snelling, Merced County, on May 28, 1915, C. L. Camp (MS) observed that young "evidently just emerging for the first time in their lives, seemed confused when they saw a horse and buggy and often ran almost directly under the wheels." Two months later, in the high mountains, the young squirrels behaved the same way. A probably abnormal occurrence was that of a very young squirrel found on April 29 wandering aimlessly about in the grass near a burrow entrance. This squirrel weighed only 61.5 grams, or less than onetenth the weight of adults. It was practically helpless and would have fallen easy prey to any sort of predaceous animal.

The first litter of young ground squirrels seen aboveground in the season of 1918 by the junior author was noted on April 28 at 1,500 feet altitude on San Emigdio Creek, Kern County. In this litter there were six young at least one-third grown. Judging from the "sign" about the burrow, these youngsters had been foraging above ground for a week or ten days. The season at this altitude was at least ten days later than it was down on the lower parts of the San Joaquin Valley. Several burrows of small diameter and amateurish construction were found at the edge of a thick patch of alfilaria that grew near the nest burrow. These young squirrels in spite of their small size were busily harvesting the heads of the ripening alfilaria and when alarmed ran down the small burrows which each had dug for himself. While the observer was standing over one of these burrows a youngster came up halfway out of a hole six feet away, but catching sight of him gave a hasty alarm note and scurried back down the hole. Twenty-five minutes elapsed after this before any of the young squirrels reappeared above ground. 
As far as is to be observed, the male takes no active interest in the welfare of the young. Indeed, he dwells altogether separately from the family and does not see his offspring until they begin foraging out of doors. His only function at all, as regards the upbringing of the young, is that of sounding general alarm throughout the colony when danger threatens. As for the mother, even she is notably indifferent to her young after they appear above ground. When suddenly alarmed, she flees to safety on her own account, leaving the youngsters to shift each for himself as best he may.

The rate of growth of the young is such that they reach mature size by September, when they are from four to six months old (MeCoy, 1912, p. 1069). But before this time, by the first of August, the young of the year begin to emigrate locally, so as to establish each for himself a new home. It is likely that this process of emigration is hastened by the development on the part of the parents of an attitude of incompatibility. According to this idea the initial solicitude of the mother for her young at the helpless age is later reversed, so that she becomes antagonistic to them and finally speeds their departure. The young, at the same time, begin to give evidence of an instinct to wander. At any rate, the month of August sees the important phenomenon of emigration or dispersion well under way. Young of the year then put in their appearance in unexpected places; new ground is invaded, and the total territory occupied by the squirrels increased in extent insofar as the increase in population makes necessary and the favorable nature of the country permits. Undue congestion of population tends thereby to be prevented.

The natural enemies of the California Ground Squirrel are of many kinds, and under original conditions so many as regards individuals as to provide a regular automatic check to any abnormal increase of the squirrel. The most important are golden eagles, red-tailed hawks, coyotes, badgers, wildeats, weasels, rattlesnakes and gopher snakes. Each of these various animals pursues the squirrels in its own particular way. Hawks and eagles swoop down on them from their vantage points in the air. Wildeats and coyotes lie in wait near the burrows until the squirrels venture forth in search of food, when they pounce upon them. Badgers, weasels and snakes capture the squirrels in their burrows. Some specific cases will be cited here. It must be remembered that, while casualties to squirrels may be inflicted by their eustomary enemies almost hourly in any general neighborhood where man has not exterminated these predators, the chances of a person's being in a position at the critical moment to witness a tragedy of this sort are rare. At the San Emigdio Ranch in Kern County on April 25, 1918, the junior author watched a Golden Eagle (Aquila chrysaetos) capture and devour an adult ground squirrel. The eagle was first observed flying quietly down a canyon. By weaving in and out in its course the bird was able to skirt the irregular hillside so as to keep within fifteen or twenty feet of the ground. At length the eagle skimmed abruptly around the shoulder of a hill, just clearing the tops of the wild oats, and dropped quickly down upon a luckless ground squirrel. The latter had evidently been on a foraging expedition and did not have time to reach his burrow, so complete was the surprise. The eagle seized the squirrel with both sets of talons, and the piercing grip by these effective 
instruments quickly dispatched it. The bird then proceeded to tear the animal to pieces with the stout beak and, perched on the ground, devoured it on the spot. The strategy and success of this method of attack was obviously dependent upon the eagle keeping close to the ground so as to remain out of the squirrel's range of vision until the last moment.

At Pleasant Valley, Mariposa County, on May 17, 1915, C. L. Camp (MS) fed a ground squirrel that had been shot, to a Golden Eagle kept captive by a storekeeper there. The eagle ate head, skin and bones, but discarded the stomach and large intestines. Other birds, such as the turkey vulture, have been observed by the junior anthor to similarly avoid the stomach and intestines of ground squirrels that have been killed by taking poisoned barley. Coyotes have also been known to show the same fine discrimination when eating ground squirrels which they themselves have not caught.

Some idea of the success with which Golden Eagles sometimes pursue ground squirrels may be had from the fact that at Lilac, San Diego County, on April 4, 1907, James B. Dixon (MS) found eleven freshly caught ground squirrels in and about an eagle's nest that contained two eaglets about a week old.

During the spring of 1904 W. L. Finley and H. T. Bohlman observed and photographed a pair of young Golden Eagles in various stages of development from the time the eaglets were nine days old until they left their birthplace nearly three months later. The aerie was a bulky affair placed in a horizontal fork of the upper limbs of a large sycamore tree that grew in a canyon back of Mission San Jose, Alameda County. In speaking of the food of the Golden Eagle, Finley (1906, pp. 9-10) says: "His food consists almost entirely of the ground squirrels that are so abundant through the California hills. On our second trip [on April 12], when we looked into the nest, we found the remains of the bodies of four squirrels lying on its rim. At each visit we examined the food remains and the pellets about the nest, and we are sure that a very large proportion of the eagles' food supply consisted of squirrels. ... I am satisfied that this family of eagles regularly consumed an average of six ground squirrels a day during the period of nesting, and, very likely, more than that. . . . But even this low estimate would mean the destruction of 540 squirrels along the hillsides in about three months' time."

The nest of a Western Red-tailed Hawk (Buteo borealis calurus) examined by J. B. Dixon (J. Dixon, 1917, p. 12) on March 28, 1906, and containing one day-old chick, two pipped eggs and a rotten egg, was found to contain also the remains of two ground squirrels. This was near Vista, San Diego County. At Pala, in the same county, the same observer found the nest of a Red-bellied Hawk (Buteo lineatus elegans), April 3, 1916, containing three young, a week old, together with one ground squirrel and two pocket gophers. The dead squirrels counted in the nests represent, of course, merely the surplus which the old birds had just carried to the young. The squirrels that the old birds themselves or the young may have eaten on the day of observation are not taken into account.

At Dunlap, Fresno County, on September 30, 1916, H. S. Swarth (MS) found a large rattlesnake (Crotalus oreganus) which showed a 
bulge in the middle portion of its body. This proved to mark the loostion of a full-grown ground squirrel, which had been swallowed entire, head first.

Near the mouth of 'Tejon Creek, Kern County, on July 16, 1914, C. L. Camp (MS) watched a rattlesnake (Crotalus oreganus) about three feet and a half long, swallow a ground squirrel. He describes the incident essentially as follows: The snake had just bitten the squirrel on the side of the face below the eye. The squirrel flopped about for five or ten minutes and then dropped over a bank and died, out of sight of the snake. The snake then slowly crawled down over the bank after its prey, found it, touched it all over with the end of its tongue, and then seized the animal by the nose. The squirrel moved slightly. The snake drew back and waited motionless for some time. The snake then got a fresh hold on the squirrel's nose, pulled the body out straight, and started to work its jaws over the squirrel's head. Things went rapidly as far as the squirrel's ears, then operations proceeded more slowly. The suake writhed about and gradually worked its jaws over the shoulders of the squirrel, first moving the upper jaw forward with slight jerks and then pulling up on the lower jaw. Finally, after the rodent had been half swallowed, we approached closer to take a picture and the snake disgorged the squirrel as the result of a violent effort lasting a minute or so. We went away and in a little while the snake returned to its food and had swallowed it almost completely within 15 or 20 minutes more.

On Pine Flats, in the San Gabriel Nountains, a large, lazy rattler was secured which showed a bulge about halfway along its body. Dissection disclosed a full-grown California Ground Squirrel which had been swallowed. (Grinnell, J. and H. W., 1907, p. 53.)

On San Emigdio Creek, Kern County, on the morning of April 23, 1918, the attention of J. Dixon (MS) was attracted by the nervous barking and peculiar actions of a large male ground squirrel. With the aid of the binoculars, the actions of the squirrel, which was less than 75 yards distant, were easily followed. The squirrel was obviously much wrought up and his sharp, nervous notes were quite different in pitch and intensity from the ordinary metallic alarm note. The animal's attention was continually focused upon an opening just beneath a certain small white rock at the edge of a stone pile. While his attention thus remained fixed, the squirrel kept running back and forth in a semicircle about thirty inches distant from the object concerned. During this time the squirrel's tail, which was held arched over his back, was twitched violently sideways every time he barked. The alarm notes were uttered during a momentary pause at the end of each advance in the arc-shaped path of the squirrel. The squirrel's whole demeanor reminded the observer of that of a pup that has cornered some old pussy cat and still hesitates to make an attack. Having witnessed three similar performances by ground squirrels, in San Diego rounty, the observer proceeded to investigate and found, as in the three previous instances, that a coiled rattlesnake was the cause of the excitement. In the present case there were two, a male and female, tightly coiled together at the mouth of a squirrel burrow, and they were dispatched. An hour later this same squirrel, which was easily identified by a peculiarity in its pelage due to wear, was observed digging a new 
burrow some fifty feet distant from where the rattlesnakes had been. There was no way of determining whether the presence of the snakes had influenced this action, but it was evident that this squirrel made no effort to fill up the entrance to the burrow which had been preempted by the snakes. It is a popular notion that ground squirrels, when the opportunity offers, bury snakes alive.

As for mammals as enemies of ground squirrels, the evidence most readily obtainable is derived from examination of the excrement of the former. Coyotes have regular places for deposit of excrement, on hill tops or ridges. Bones and teeth of ground squirrels frequently have been found represented in these deposits (J. Grinnell, MS). The remains of two freshly eaten ground squirrels were found in the stomach of a wildcat killed in central San Diego County (J. Dixon, MS).

As to food, the California Ground Squirrel shows a wide range of taste, even though there are at the same time decided preferences. He cheerfully adopts substitutes when favorite foods are lacking; he is not averse to taking considerable barley with his wheat. A list of all the plants eaten by the ground squirrel would be a very long one, and if locality be taken into account great variation would doubtless be found from place to place. The above general statements will be borne out, in part at least, by the data presented in the paragraphs to follow.

On the University campus at Berkeley, on March 13, 1918, the majority of the California Ground Squirrels were feeding on the tender leaves of alfilaria (Erodium). A female squiriel was observed by the junior author at this time to eat the leaves of young plants of the star thistle (Centaurea). On San Emigdio Creek, Kern County, on April 28,1918 , a squirrel was seen to disappear down a hole carrying a sheaf of freshly cut heads of foxtail (Hordeum) held tightly in his mouth. A few minutes later this squirrel was gassed and when the burrow was dug out the fresh foxtail heads were found on the edge of the nest. Previously this squirrel was seen to gather heads of both foxtail and alfilaria, but preference was given to the latter (J. Dixon, MS). The young as well as the old squirrels seem to prefer alfilaria. when obtainable to any other plant.

In the region about Walnut Creek, Contra Costa County, on July 26 and August 16, 1918, the authors found ground squirrels feeding extensively on seeds of bur clover (Medicago hispida). Dried burs of this plant were abundant on the hillsides in the near vicinity of the squirrel burrows, and although there was a plentiful supply of barley on the adjacent stubble fields this was in major part passed up in favor of the clover seeds. Hulled seeds of the bur clover were found to predominate in the cheek pouches and the stomachs of the score or more squirrels that were shot. This fondness on the part of the ground squirrels for bur-clover seed suggests a possibly better way of poisoning these rodents by using the entire bur of the clover than by the use of barley, wheat or other grains, which are now so bacily needed for human consumption.

In southern California the seeds of the plant known as wild cucumber, manroot, or chilicothe (Echinocystis macrocarpa) is eagerly sought by ground squirrels. Gnawed hulls of the seeds of this plant are frequently found in large quantities near the summits of rock piles where the husking or lookout stations of the squirrels are located. In Yosemite 
Valley a ground squirrel was seen gathering green fruits from the top of a four-foot manzanita bush.

C. H. Merriam reports $(1910$, p. 5$)$ that the seeds of the manroot (Echinocystis fabacea) are eaten in the vicinity of Modesto from the middle of May to the middle of December. The seeds are eaten from

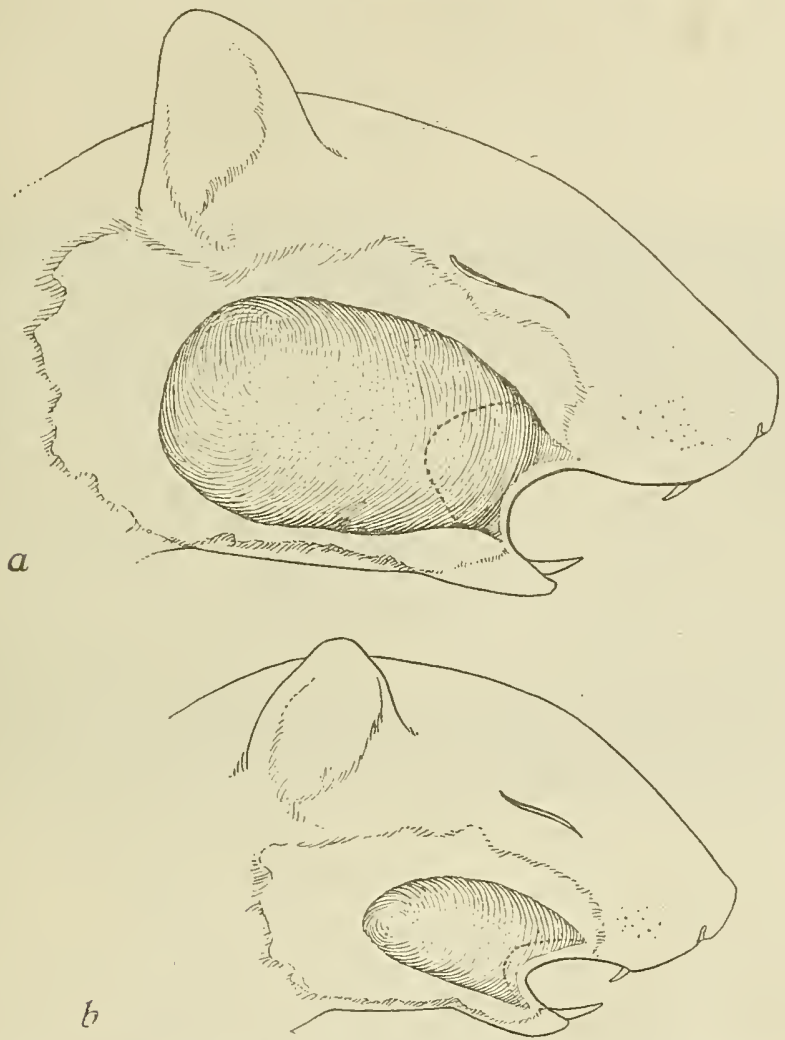

FIG. 13. Drawings from dissections to show relative extent of cheek-pouches in (a) California Ground Squirrel and (b) Belding Ground Squirrel. One cheek-pouch opens into the mouth cavity on each side; it is lined with membrane continuous with that lining the mouth and is used for carrying food materials such as seeds and bulbs from the forage ground to either the store house or the husking place. It is to be inferred that the California Ground Squirrel is much more of a seedgatherer than the Belding. The latter, like the Oregon Ground Squirrel, is more of a grass-eater, and also does not garner food to the extent that the "digger" squirrels do.

the time they begin to form until they are fully ripe. "Other favorite seeds are those of elderberry (Sambucus), jimson weed (Datura), wild nightshade (Solanum), turkey mullein (Eremocarpus), tarweed (Madia), and aumerous grasses. . . . In southern California the squirrels are fond of the fruit of the prickly pear (Opuntia)."

Ground squirrels are provided with more or less extensive, membranelined cheek pouches opening inside the mouth, which are used in gathering and transporting food (see fig. 13). Often when the animals are scared out of weed patches or bushes, or away from some supply of roots 
or bulbs which they have discovered, their cheeks are seen to be bulging with the contents of these pouches. They are able to operate their teeth and lips even when these pouches are copiously distended. The cheek pouches of the California Ground Squirrel are especially well developed and this, we think, is correlated with the pronounced seed gathering and storing propensities of this species. The following records of cheek-pouch contents, as secured from specimens collected, contribute further to our knowledge of the kinds of food of this animal and also of the quantity in which these may be gathered.

A female taken in a stubble field near Walnut Creek, Contra Costa County, July 26, 1918, held in her cheek pouches 26 seeds of bur clover. A male taken August 15, 1918, at the same place had 78 seeds of bur clover and one seed of needle grass. Two other males had one and three bur-clover seeds, respectively. Another female taken at the same time and place contained 212 seeds of bur clover and 12 seeds of some kind of wild grass. Another male held 97 grains of barley and three bur-clover seeds. A ground squirrel taken at Cisco, Placer County, on October 9, 1913, was carrying 92 seeds of the green manzanita (Arctostaphylos patula), while a squirrel secured near Pleasant Valley, Mariposa County, on May 28, 1915, had dug up and was carrying in its pouches 12 bulbs of a species of wild hyacinth (Brodica hyacinthina). At El Portal, Mariposa County, a squirrel was secured with three large acorns of the golden oak in its cheek pouches.

We will now consider those feeding habits which make the California Ground Squirrel come into conflict more directly with man's interests. "Of cultivated nuts, almonds and walnuts are preferred; of other crops, apples, prunes, peaches, apricots, figs, olives, ... the seeds of cantaloupes, watermelons and citron melons, and all the grains are eaten whenever they are to be had, and green alfalfa and clover are sometimes taken" (Merriam, 1910, p. 5). Frank Stephens (1906, p. 66) has summed up the food taken by this animal as follows: "The food is principally of a vegetable nature, preferably grain and other seeds, fruit, potatoes, green plants, etc. Eggs of poultry and wild birds are relished." We have heard considerable testimony from ranchers to the effect that individual ground squirrels in different localities have learned to raid henneries, so that the above statement is not exceptional.

A great deal of damage is done by California Ground Squirrels each year in orchards and vineyards. The following instances, given by Merriam (1910, p. 6) are typical of such depredations. "Ground squirrels are particularly fond of green almonds and of the pits of green peaches and apricots, eating these from the time the kernels begin to form until the fruit is ripe, thus doing serious damage. They are very destructive to apples also, and in places in the foothills of the Colfax-Auburn region are said to take fully half the crop. ... In the fall of 1907 E. A. Goldman reported that they were doing serious damage to young vineyards about Orosi, in Tulare County, by biting off the leaves and tender shoots of the vines.... In the orange groves between Porterville and Springville, in Tulare County, it is reported that they occasionally gnaw the bark of the orange trees and sometimes cut the fruit and carry it off. Besides destroying nuts and fresh fruits they attack drying prunes and carry off large quantities." 
On May 14, 1918, near the mouth of Caliente Creek wash, Kern County, in one corner of a 640 -acre field planted to wheat, four large bare spots were counted by the junior author in an area of not over ten acres. These denuded areas were circular in shape and averaged 75 yards in diameter. They were caused by the ground squirrels having eaten and destroyed the ripening wheat and even the stalks so that nothing but weeds remained. In a single one of these denuded areas twenty-three occupied squirrel burrows were counted. In this same field, within a six-foot circle the center of which was a lone squirrel burrow, 113 heads of wheat were picked up (see fig. 14). These heads

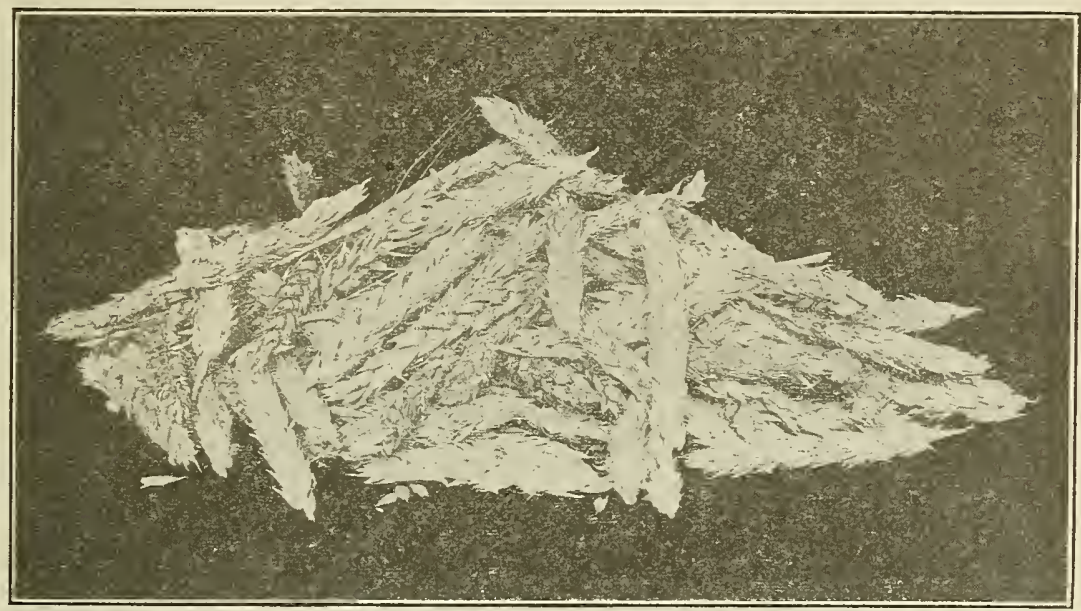

FIG. 14. These 113 heads of wheat were picked up within a six-foot circle, the center of which was a "digger" squirrel burrow situated in the edge of a wheat field. They were part of what had been gathered within three or four days, apparently by the one squirrel.

had all been cut and carried to the burrow within three or four days, as they were not yet dry. This was evidently the work of a single squirrel, since no other squirrel was seen to go near the burrow. These 113 heads of wheat probably constituted part of what was intended for storing, and did not include that required for current consumption.

In gathering food California Ground Squirrels slink along slowly close to the ground, often half hidden in the grass. In gathering ripe alfilaria only the clusters of seed cases are taken, with relatively little of the stem. However, when the plants are young, the stems and leaves are much relished by the squirrels. The usual method of feeding as revealed by the binoculars, is for the squirrel to sit up on his haunches within reach of the alfilaria heads, which are dexterously gathered into little bunches by the front paws of the animal and then quickly snipped off by the sharp ineisor teeth. During this last operation the head of the rodent is often inclined to one side. In gathering bulky food materials such as the heads of foxtail the cheek-pouches are not always used, the material being carried crosswise in the squirrel's mouth directly to the burrow.

On the San Joaquin River near Mendota R. M. Hunt (MS) reports seeing squirrels go cut into the tules of the sloughs seemingly to eat the 
green stalks. Several times on following up rustling sounds squirrels were discovered on thick mats of dry fallen tules among the standing green ones and just above the water. One, on being alarmed, jumped into the water with a splash and, although lost to sight, probably reached safety by swimming. Davis "Island," near Mendota, is part of the mainland at low water, but in May, with high water, becomes a true island and with the highest water the ground everywhere is completely submerged. On June 20,1918, a squirrel was discovered on this island. It jumped from a piece of ground into the water and swam, in much the manner of a dog, to a tree up which it took refuge.

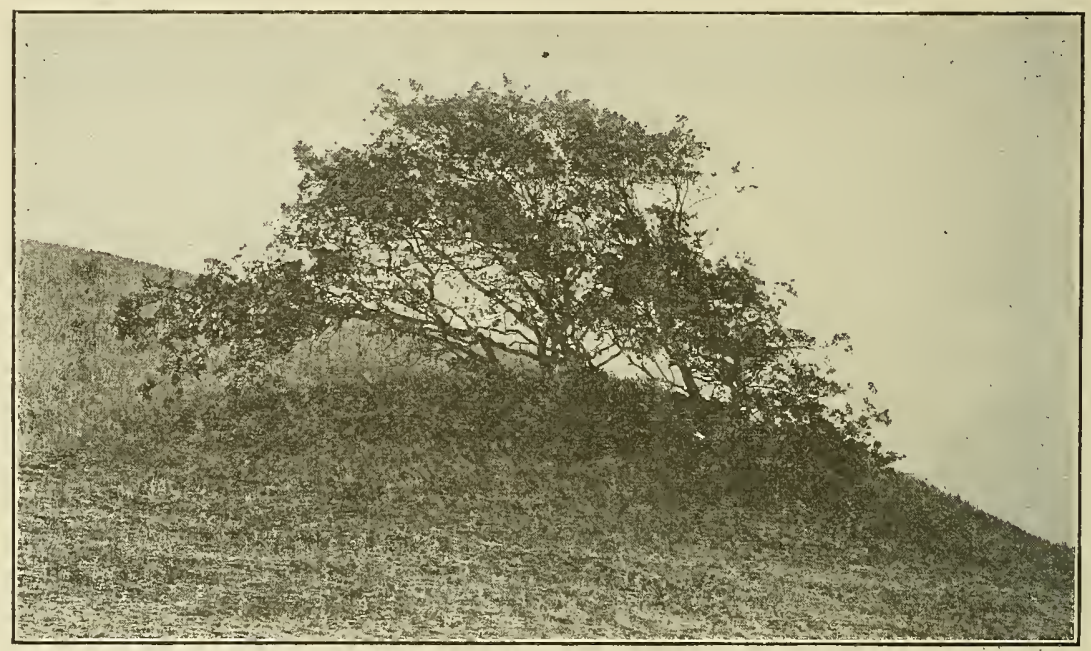

FIG. 15. Metropolis of "digger" squirrels under a small oak on a grain-sown hillside; photographed near Walnut Creek, Contra Costa County, August 15, 1918. Owing to the dryness of the season and to the depredations of the squirrels, the grain on the hill above the oak had been left uncut.

A current report was to the effect that each year at high water ground squirrels are marooned on this island and live for the time being in the big hollow-trunked willows there. This shows that flooding does not necessarily drive out or drown these squirrels in such localities as afford refuges on high ground or in trees.

On wild land, alfilaria, foxtail and bur clover are perhaps the three plants that are eaten to a greater extent than any other of our forage plants. Alfilaria is eaten from the time it appears above ground until it ripens, and even after that, when the seeds have seattered out, they are gathered and either eaten at once, or stored. The long, curled "propellers"' are broken off and discarded. In Strawberry Canyon on the University campus, in April, the squirrels were harvesting foxtail and alfilaria on sunny southern exposures where the plants had matured early. Later in the season, during late June and early July, these same squirrels with their families of half-grown young were found to have moved down the hillsides, some 150 yards, to the moister, shady ground near the creek bed where the foxtail was still green, and here they were busily gathering the foxtail heads just ripening on July 6 . There is an obvious rotation in the use of the different important plants for food, 
dependent upon the sequence in which they become available. Thus, alfilaria is eaten during winter and early spring; then the foxtail crop claims attention; and the bur clover, after its seeds ripen, is harvested all through midsummer and autumn. Of course the above statements are only of local application.

Examination of the food stores of ground squirrels would go far toward providing adequate knowledge of their food habits. Such investigations should be made preferably in the fall. Specific information now available is as follows:

In digging out a colonial burrow near Bakersfield, Kern County, on May 3, 1918, a storehouse was uncovered. This consisted of a cavity or pocket off the main run (see $a$, fig. 8), which measured five and a half by eight inches in two diameters and was eighteen inches beneath the surface of the ground. The stored food consisted of a double handful of nearly dry heads of foxtail grass carefully packed in dry sand. A few alfilaria seeds were also included with the foxtail, but alfilaria was scarce at this locality.

Upward of fifty of the button-like seeds or "cheeses" of the mallow (Malva) were observed at the entrance of another burrow at the same place, but the observer was unable to determine whether or not these seeds were being stored. The mallow seeds were found for the most part on the lookout station at the entrance to the burrow.

"At Modesto in May, 1909, Piper found stores of alfilaria seeds packed in cavities and well mixed with dry sand. In December of the same year he examined a number of stores of grain unearthed by a farmer while scraping and leveling his land. Each of these caches consisted of from a pint to a quart of oats stored in cavities and packed in dry sand. They varied from 8 to 18 inches in depth beneath the surface; some were in short blind holes; others at the ends of branches of the main burrow" (Merriam, 1910, p. 5).

An idea of the quantity of food eaten by the California Ground Squirrel can be derived from the following data:

A female taken near Coulterville, Mariposa County, on June 3, 1915, weighed 553.5 grams, or about a pound and a quarter. The stomach and its contents alone weighed 77.5 grams, or about $2 \frac{3}{4}$ ounces (C. L. Camp, MS). Figuring out the ascertained weight of the stomach in other individuals, 5 grams, the ratio of stomach contents to total weight in this squirrel proves to have been about 1 to 7 . The material represented is presumed to have been fresh green stuff.

Some experiments have been carried on at the Museum with captive squirrels with the purpose of determining the amount of green forage consumed daily. Fifty grams, or nearly two ounces, of green alfilaria was found to be the average daily ration for an average-sized squirrel. In cases where all food had been withheld from the squirrels the previous day, the greatest amount of succulent alfilaria, the favorite food of the squirrel, consumed in one day was 80 grams, or somewhat less than three ounces.

Five immature ground squirrels taken July 26, 1918, near Walnut Creek, Contra Costa County, gave an average total weight of 504.3 (427.2-517.2) each in grams. The average weight of the stomach contents in these five squirrels was 13.2 (10.3-19.0), so that the average ratio of the weight of the stomach contents to the total weight was 
1 to 38 ( 1 to $50-1$ to 22 ). The stomach contents in these cases consisted almost entirely of finely chewed seeds of barley and bur clover. The squirrels were shot between noon and 2 p.m. Seven full-grown males taken on August 15, 1918, near Walnut Creck, gave an average total weight of 659.4 (576.8-724.7) grams each; the average weight of the stomach contents was $17.9(11.5-20.5)$; and the average ratio of contents of stomach to total weight was 1 to 37 ( 1 to $63-1$ to 30 ). Seven full-grown females taken at the same time and place gave an average total weight in grams of $500(370.7-681.4)$ each; the average weight of the stomach contents was 9.7 (5-15.8); and the average ratio of contents of stomach to total weight was 1 to 42 (1 to 101-1 to 37 ). All these fourteen squirrels were foraging in stubble fields, and the stomach contents consisted of barley and bur clover seeds finely chewed and of nearly the same degree of moistness as ordinary baker's dough. The squirrels were shot between $10 \mathrm{a} . \mathrm{m}$. and noon.

It is believed by us that two ounces of green forage or one-half ounce of dry grain is an average stomach-full for an average-sized California Ground Squirrel and that two stomach-fulls represent a day's ration. It is evident that the proportion between the weight of the stomach contents and the total weight averages considerably less in this species than it does in the Oregon Ground Squirrel. The California is more of a seed eater and less of a grass eater than the Oregon Squirrel and therefore enjoys a more condensed ration.

During late summer digger squirrels, particularly the old adults, become exceedingly fat. In this condition they become obviously lazy and may often be seen lounging at the entrances to their burrows simply enjoying the sunshine. As the season farther advances, a decided decrease in squirrel population is noted. The active young of the year are still foraging abroad, but even these restrict their activities to the brightest hours of sunshiny days. What becomes of the squirrels which have altogether disappeared underground?

One would naturally expect that the life history of such a notorious animal as the California Ground Squirrel would be known pretty thoroughly. However, such does not seem to be the case; there are several features of the underground life of this squirrel in regard to which our information is very inadequate and of which from the standpoint of rodent control it would be most useful to know. As has been previously mentioned, little appears to be definitely known regarding the period of gestation of this animal. The condition of the young at birth and their subsequent eare and development is also not well known. Another moot point is that of æstivation or hibernation of this species of ground squirrel. Merriam (1910, p. 4) states that "this species does not hibernate, except in the mountains, although in the foothills and valleys the animals usually stay in their burrows during stormy and severe weather. At the upper limit of their range, where the ground in winter is covered with snow, they may remain underground long enough to be said to hibernate, but over the greater part of the state they are out in numbers every month of the year." However, we believe we have evidence to indicate that a period of astivation or hibernation (or the two combined), in other words a state of torpidity initially induced by the heat and dryness of summer, obtains among some at least of the adult ground squirrels even in the lowlands. This 
period of dormancy extends from late summer well through midwinter, and thus "æstivation" may be said to go over directly into true hibernation. The old adults seem to be the only ones that "hole up," for the young adults somewhat less than a year old, that is, the young of the year, may be seen about the burrows during suitable weather throughout the winter.

In support of the above belief, that a period of torpidity overtakes the older individuals of the squirrel population regularly each year, the following evidence is submitted:

(1) Close watch, extending over a period of between four and five years, was kept on a female ground squirrel that lived in the dooryard at the home of Mrs. Elizabeth Grinnell in Pasadena. This particular squirrel did not æstivate until its second year. Then and during each succeeding year of its life it astivated regularly, becoming very fat and retiring to its burrow during the last week in August. It emerged lean and hungry, with marked regularity, about the twenty-second of each following February. When removed from the burrow at intervals during this period, the squirrel was found to be in a torpid state, with respiration not perceptible.

(2) In a case in the junior author's personal experience, near Escondido, San Diego County, all the squirrels that were active in a certain field in the fall were poisoned or otherwise killed, and yet old breeding squirrels suddenly appeared in this same field the following February. This occurred when there was seemingly no possible chance for reinfestation from the surrounding fields, which had been cleaned up also. Similar testimony has reached us from a number of men identified with efforts to exterminate these rodents.

(3) It occurred to the present writers that it might be possible through the examination of specimens to learn the extent to which old adults are out in midwinter. The heads of 186 ground squirrels were, at our request, secured by the United States Public Health Service, shot and trapped near Martinez, Contra Costa County, during January, 1918, and sent to the Museum of Vertebrate Zoology, where the skulls were cleaned and carefully examined. Relatively advanced age was determined from the skulls upon the following criteria: general size, zygomatic breadth, breadth of jugals, stoutness of postorbital processes, degree of development of sagittal crest, degree of approach of parietal ridges, breadth and degree of concavity of frontal surface, advance in coalescence of the adjacent bones along certain sutures, and amount of wear on the crowns of the molariform teeth.

The results of our examination are given in Table II:

TABLE II. Proportions of adult to young ground squirels abroad in midwinter.

\begin{tabular}{|c|c|c|c|c|}
\hline Date received (in 1918) & $\begin{array}{l}\text { Total } \\
\text { number of } \\
\text { skulls }\end{array}$ & $\begin{array}{l}\text { Number } \\
\text { of old } \\
\text { adults }\end{array}$ & $\begin{array}{l}\text { Number } \\
\text { of young } \\
\text { adults }\end{array}$ & $\begin{array}{l}\text { Ratio of } \\
\text { old adults } \\
\text { to total }\end{array}$ \\
\hline January 8 . & 18 & 1 & 17 & 1 to 18 \\
\hline January 14 & 34 & 4 & 30 & 1 to 8.5 \\
\hline January 22 & 86 & 18 & 68 & 1 to 4.7 \\
\hline January 24 & 48 & 11 & 37 & 1 to 4.3 \\
\hline
\end{tabular}

The foregoing data are not nearly as complete as could well be desired, but as far as they go they show that "old adult" squirrels are relatively" 
scarce aboveground in January as compared with the younger animals, those probably less than one year old. Further, the proportions of old to young increases rapidly towards the last of that month; in other words, as the breeding season approaches. It is probable that the full old-adult population is not abroad aboveground until the last of February, when the ratio of old adults to young of the previous year would certainly not be nearly so little as 1 to 4 , which is the minimum possible at the immediate close of the breeding season.

In spite of the above lines of evidence, the real extent of this habit of rstivation among our ground squirrels is not satisfactorily known. It is exceedingly difficult to follow any individual squirrel under perfectly normal conditions through all its various activities for any great length of time. However, an important factor concerned in the work of destroying these animals is suggested; that is, the desirability of placing emphasis upon the need of poisoning in the spring rather than in the fall, when part of the breeding stock may be stowed away out of the reach of poisoned grain. It is a question, too, whether ol: not a dormant animal, in which respiration is extremely slow, would be fatally injured by a fumigant before the latter would be dissipated.

Human interest in the California Ground Squirrel naturally concerns itself most especially with the questions of total population, rate of increase, and rate of re-invasion of territory previously cleaned of squirrels. As to the first question, we have found it clifficult to find an accurate basis for determining the squirrel population living on any given unit of area, such as an acre or a square mile. Counts may be taken of living squirrels that happen to be aboveground at any one time, or of burrows which give evidence of current use. In the first case the count is never likely to cover all of the squirrels in the area, because the chances are overwhelmingly against all of the squirrels being aboveground at one time. Season of the year, time of day, and state of weather will affect profoundly this proportion of squirrels below ground to those in sight. In the latter case some sort of estimate of ratio of squirrels to burrows must have been arrived at. Season of the year must again figure importantly in the estimate, because of the jump in population following the breeding season, and progressive decrease thereafter.

On July 26, 1918, the authors took two censuses of ground squirrels on a badly infested ranch about three miles northwest of Walnut Creek, Contra Costa County (see fig. 16). The first census was taken on a south-facing hillside on an area 100 feet square, approximately onefourth of an acre. Three counts gave 19, 16 and 17 squirrels, respectively, in sight at once. Twenty-five open burrows were counted in this area. 'This, therefore, was at the rate of 76 squirrels and 100 burrows per acre, or $1 \frac{1}{3}$ burrows to each squirrel. The breeding season at that date was well passed. Allowing one adult to every four young gave fifteen adults to every 100 burrows or between six and seven open burrows to each adult squirrel after the breeding season.

The second census was taken in a mowed field from which a crop of barley hay had been recently harvested. The area taken was on a north slope and measured 250 feet square, covering abont 1. $\frac{1}{5}$ acre. Three counts were taken between noon and one o'clock. The number of squirrels seen out at once was 25, 26 and 25, respectively. Sixty burrows 
were counted in this area, so that the infestation was at the rate of 20 squirrels and 50 holes per acre. This is at the rate of $2 \frac{1}{2}$ burrows to each squirrel.

On May 28, 1918, a single isolated colony was investigated at a point twelve miles west of Fresno. This colony was in a plowed field which had been planted to grain for several years past. Here, in an area 100 feet square 16 squirrels, eight of which were less than half grown, and 17 burrows were counted. The ratio here was close to one burrow to each squirrel. This figure, again, applies to a period after the close

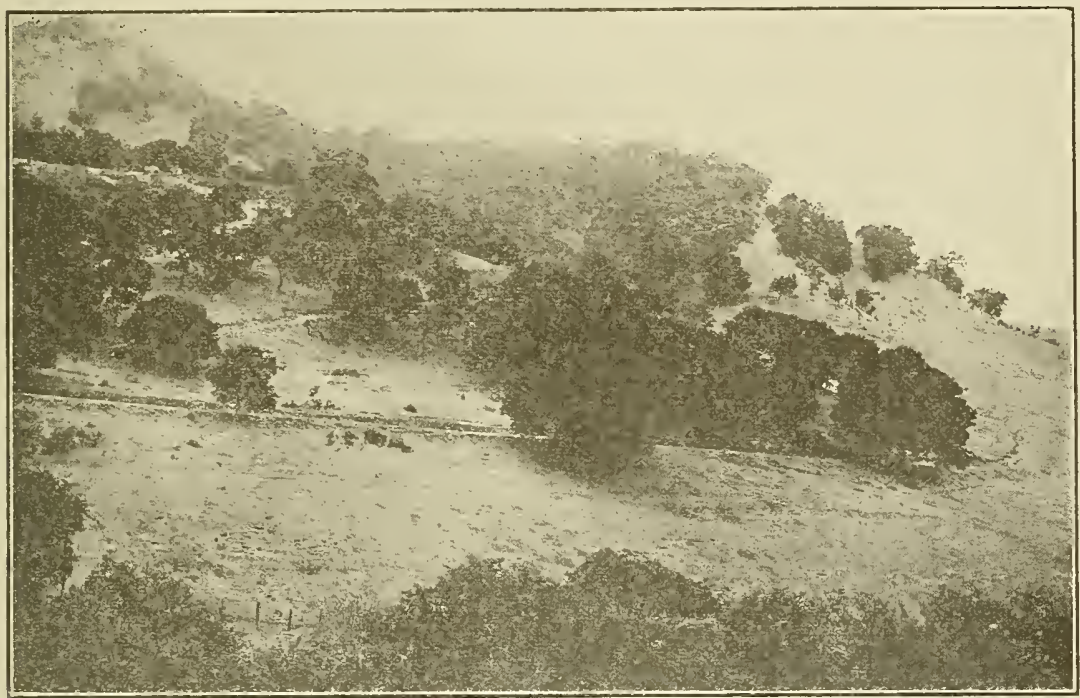

Frg. 16. Hillside near Walnut Creek, Contra Costa County, badly infested with "digger" squirrels. On August 15, 1918, squirrels were here present at the rate of fifty per acre. From this breeding ground they were at this time invading the grain fields on the opposite slope.

of the breeding season, when the squirrel population had reached its maximum.

Counts taken before the breeding season naturally give different results. At Berkeley on March 13, 1918, the junior author counted 47 squirrel burrows in a colony which occupied about one acre on a hillside. By counting the squirrels which appeared aboveground in this area on several successive days it was ascertained that there were about nine adult squirrels inhabiting this acre of ground. This gave an average of over five burrows to each squirrel.

The above-cited instances are based on maximum infestation. Local distribution is often very irregular, since squirrels may be abundant on the southern exposure of a hill and yet be entirely absent on brushy northern slopes only a hundred yards or so distant. Even on the plains and in the valleys, although the distribution is much more uniform, there is often marked unevenness in infestation irrespective of human interference. Surgeon John D. Long (1912, p. 1596), in comparing the cost of the various methods of destroying ground squirrels, based his estimates of cost on an infestation of ten holes per acre. Presumably, this was taken as representing an average infestation according to 
the experience of the United States Public Health Service in their eradication work. This appeals to us as a fair estimate on well-populated territory, such as that around San Francisco Bay.

It is the authors' belief that if the entire area in California occupied by this species be taken into consideration a population of one squirrel per acre, or 640 per square mile, at the conclusion of the breeding season, would be a fair average. At this rate there would be a total population of 32,000,000 California Ground Squirrels in the state in July, and onefourth this, or 8,000,000, in March, before the young of the year are out. If the closely allied Fisher and Douglas ground squirrels be included, as from an economic standpoint might well be done, the "digger squirrel" population of the state in summer, when crops are maturing, may be put at between 40 and 50 millions, in this state.

As for rate of increase, we are dealing with a prolific animal. As already shown, the average size of the litter in the California Ground Squirrel numbers practically eight. Males and females are present in a general population in about equal numbers. Even though but one litter is reared by each female squirrel each year, this would mean that for each pair of squirrels at the beginning of the breeding season there will be ten individuals at the close of the breeding season. The evidence we have examined goes to show that all the squirrels breed the first year of their lives-that is, when each is not quite one year old-as well as subsequently, and that the life-time of a squirrel, if it dies of old age, is five years. If we do not count upon any fatalities, one pair of squirrels can be reckoned on to give origin to a population in five years of 6,250 !

In recent efforts to eradicate squirrels a 90 per cent efficiency has been currently estimated. This means that, if no follow-up campaign be waged, ten squirrels out of each original 100 will be left, to form a nucleus of future increase. At the end of the second year the population would be back to normal. Supposing, further, that a follow-up campaign is waged at the end of a suitable interval before the next breeding season, also with a 90 per cent effectiveness; then only one squirrel per original hundred would be left. Even then, when only six squirrels are left on one square mile, these in the third breeding season will produce, barring normal fatalities, the original 640 , with a good margin to spare.

The factors limiting the population of ground squirrels under natural conditions, that is, as not affected by human agency, include the following, in the order of probable importance: (1) Quantity of food available at the season of the year when food is scarcest; (2) natural enemies, including predatory mammals, birds and reptiles; (3) adverse weather conditions, recurring rather infrequently, as when territory is inundated during exceptionally heavy rains; (4) disease; (5) old age. The rate of increase, through long ages, has been adjusted to more than meet the expected death rate from all causes combined. This rate of increase, fourfold each year, is now inherent and we have no reason for expecting any abrupt and permanent change in it either way.

With the arrival of the white man and his accessories in California, the natural balance has been upset. Man has destroyed a large percentage of the natural enemies of the ground squirrel. Cultivation of the land has, on the other hand, in portions of the state improved the food supply. The general tendeney is for the squirrels to breed up on 
uncultivated land where they are least molested through human agency, and from this they spread out and invade nearby cultivated fields. The process is most conspicuously in evidence during late summer consequent upon the emigration of the young of the year, this being in compensation for the tendency to congestion of population brought on during the breeding season.

Reduction in the food supply locally causes the squirrels to spread out in search of new pastures. Such movements are usually less than a mile in extent, and of course come particularly to notice in the vicinity of grain fields and orchards to which the squirrels drift at the time the crops begin to ripen. Some idea of the rate with which ground squirrels reinfest cultivated fields which are adjacent to wild land may be had from the following instance. Mr. O. N. Garrison of Earlimart, Tulare County, stated in an interview that during the spring of 1918 thirty-six ground squirrels were drowned out on a five-acre field of alfalfa at the first irrigation and this in spite of the fact that the field had been free from squirrels at the end of the previous irrigation season in the fall of 1917.

From the earliest times of which we have record to the present day the California Ground Squirrels have given the impression of abundance. Changes in the status of the species within history have only concerned local occurrence. There is nothing to show that there has been any extension of the general range of the species, or any retraction in it either. As already set forth, the arrival of the white man and the institution of agriculture has undoubtedly had the effect locally of increasing the ground squirrel population. On the other hand, where man has been aroused by the seriousness of their depredations to the point of adopting and putting into force effective means of control the numbers of the squirrels have been conspicuously reduced. Thus at Earlimart on May 16, 1918, ground squirrel burrows were found to be abundant over a large acreage of " $h o g$ wallow" land. Live squirrels, however, were exceedingly scarce, only five being found on one tract of forty acres which had been thoroughly poisoned the previous season. A count taken on this tract showed that there was an average of fifty empty burrows to each squirrel present.

A very few localities have been reported in which the squirrels are, for the time being at least, things of the past; but the possibility of re-invasion presents itself, and this, as already shown, may be a very rapid process. It would seem that ground squirrels, like weeds or scale bugs, will have to be watched continually, and proper measures taken whenever necessary to prevent the reinfestation of land which is thought to have been freed.

The difficulties in arriving at a fair estimate of the damage done by the California Ground Squirrel, which is by far the most injurious species in the state, are many and various. We have tried to get at a satisfactory estimate (not a guess) in terms of dollars per annum, but have not succeeded. It may be of some interest, however, to give some other figures, indicative in partial degree of the loss that may be occasioned by this ground squirrel.

In order to ascertain the bearing of squirrels upon grazing interests we have found some basis for estimating squirrels in terms of livestock. We have weighed and examined the stomach contents of a series 
of squirrcls, with results already given. These, summarized, show that one ounce of dry grain or seeds, or four ounces of green vegetation, is consumed each day by an average California Ground Squirrel. If we take fifty pounds of green stuff as representing the amount of forage consumed daily by one steer on open range, then 200 squirrels would appropriate the forage which would keep one steer. Twenty squirrels would eat as much as one sheep, and this last estimate would be most significant, because sheep graze closer and hence the competition here would be sharpest.

Expressing this relationship in another way, taking the average population of ground squirrels on open range as one per acre or 640 per square mile, the squirrels on each square mile appropriate the forage of three steers or 32 sheep. If the entire range of the California Ground Squirrel be taken into account and be supposed to consist purely of grazing lands (and so of minimum land value) grazed to their fullest capacity, then the squirrels of this species take the place of 160,000 cattle or $1,600,000$ sheep. Of course, it is not likely that the squirrels come into actual close competition with livestock in ordinary years; but in extra dry years, such as that of 1917-18, when all the living things which depend on vegetation for support are hard pressed to maintain existence, then the squirrels cannot help but crowd the cattle interests of the country, which are of such vital human importance.

\title{
FISHER GROUND SQUIRREL.
}

\section{Citellus beecheyi fisheri (Merriam).}

\author{
PLATE V.
}

Other names.-Fisher Spermophile; Digger Squirrel, part; Spermophilus beecheyi, part; Spermophilus beecheyi fisheri; Spermophilus grammurus fisheri; Citellus varicgatus fisheri; Citellus grammurus fisheri; Otospermophilus beecheyi fisheri; Spermophilus grammurus beecheyi, part.

Field characters.-As for the Beechey Ground Squirrel, differing in paler tone of general coloration, and in more extensive and purer white shoulder patches. Length of body alone about $9 \frac{3}{4}$ inches, with tail about 6 inches more.

Description.--In all pelages: Closely like beecheyi, except for pallid tones of color predominantly light cinnamon-drab, and extension of light areas. The shoulder patches in typical fisheri are much clearer white and tend to meet on the fore back between the shoulders; in some specimens the mid-dorsal grayish brown stripe is almost obliterated by these white invasions. The back of the ear is usually grizzled buffy in fisheri instead of chiefly black, and its hinder margin and base are silvery white. The lower surface of the body and the upper surfaces of the feet are usually much whiter, less buffy, than in beecheyi.

Color variations.- The range of individual and seasonal variation in fisheri seems to be about the same as in beecheyi.

The extreme of the characters of fisheri are developed in the Inyo region, and gradual intergradation or blending takes place towards beecheyi chiefly through southern Tulare and Kern Counties. The dotted line on the map (fig. 17) separating the ranges of fisheri and beecheyi represents no place of abrupt demarcation but only somewhere near the middle of the belt of intergradation. Many individuals from the vicinity of this hypothetical line are so nearly betwixt typical beecheyi and typical fisheri that they can only arbitrarily be placed under one name or the other. This has been done with such intermediate examples in the lists of specimens examined. 
Measurements.-Average and extreme measurements, in millimeters, of thirteen mature specimens from Inyo County are as follows: Five males: total length, 417 (400-455); tail vertebræ, $163(155-180)$; hind foot, 57 (50-65) ; ear from crown, 19 (16-22) ; greatest length of skull, 55.4 (54.1-57.0); zygomatic breadth, 34.7 (33.3-36.3) ; interorbital width, 13.3 (13.1-13.9). Eight females: total length, 396 (374-417); tail vertebræ, 157 (145̄-170); hind foot, 53 (51-55) ; ear from crown, 19 (18-23) ; greatest length of skull, 53.9 (52.3-55.7); zygomatic breadth, 33.2 (31.0-34.7); interorbital width, 13.2 (12.2-14.3)

The above figures show that the race fisheri is decidedly smaller in almost every particular than beecheyi. The disparity between the sexes is quite as well shown, however, and the rest of the variable features seem to be exhibited in about the same degree, making due allowances for the smaller number of fisheri measured.

Weights.-Average and extreme weights in grams r.f eight mature specimens from Inyo County are as follows: Five males, 589 (4S0-656); three females, 400 (321-410). Averages in ounces: males, about $20 \frac{3}{4}$; females, about 14.

It is probable that a larger series of weights would give somewhat different averages. That for the females seems low.

Type locality.-Keru Valley, 25 miles above Kernville [= South Fork of Kern River 25 miles east of Kernville], Kern County, California (Merriam, 1S93, p. 133).

Distribution area.-Roughly the western borderlands of the Mohave Desert, north into the Inyo region and south as far as the northwestern arm of the Colorado Desert. More in detail, the western side of Owens Valley including the adjacent east slopes of the Sierras north to the vicinity of Mammoth Pass; east from the southern end of Owens Lake through the Coso, Argus and north end of the Panamint Mountains; the extreme southern Sierras, including the entire drainage basin of the Kern River; the southern end of the San Joaquin Valley south of Tulare Lake, and the Carrizo Plains country and adjacent hills and valleys to the westward; the Tehachapi, Tejon, San Bernardino, San Jacinto and Santa Rosa Mountains and adjacent desert borders. The approximate line of blending between the races beecheyi and fisheri is shown on the map (fig. 17). With regard to life-zone the Fisher Ground Squirrel extends from the Lower Sonoran to the Canadian but its greatest numbe"s are reached, and most of its habitat lies, in the Upper Sonoran (see fig. 23).

Specimens examined.-A total of 96 specimens from the followiug localities, all in California : Inyo County : Little Onion Valley, 7,500 ft., east slope Sierra Nevada west of Independence, 1 ; Independence, 4 ; vicinity of Lone Pine, 3 ; vicinity of Jackass Spring, 6,200-6,500 ft., northern part of Panamint Mts., 9; Little Lake, 2; Olancha, 1; Little Cottonwood Creek, at 10,000 ft. alt., 1. Tulare County: Jordan Hot Spriugs, 6,700 ft., 1; Jackass Meadow, 7,750 ft., 1; Trout Creek, 6,000 ft., 3 ; Taylor Meadow, 7,000 ft., 5 ; Cannell Meadow, 7,000 ft., 1; Earlimart, 2 ; Tipton, 5 . Kern County: Kern River, seven miles above Kernville, 1; Fay Creek, 4,100 ft., 2 ; west slope Walker Pass, 4,600 ft., 3 ; Weldon, 1 ; Isabella, 2 ; Bodfish, 1 ; Kern River, twelve miles below Bodfish, 1; ejght miles northeast Bakersfield, 1; San Emigdio, 2; Fort Tejon, 5. San Luis Obispo County : near Simmler, on Carrizo Plains, 1. Ventura County: Mount Pinos, 3. San Bernardino County : Victorville, 2 ; Cushenbury Springs, 1; Doble, 7,000 ft., San Bernardino Mts., 1 ; Bluff Lake, 7,500 ft., San Bernardino Mts., 2; F'sh Creek, 6,500 ft., San Bernardino Mts., 1. Riverside County; near Banning, 1; Cabezon, 9 ; Snow Creek, near Whitewater, 1 ; Schain's Ranch, 4,900 ft., San Jacinto Mts., 4; Fuller's Mill, 5,900 ft., San Jacinto Mts., 1; Round Valley, 9,000 ft., San Jacinto Mts., 1; Tahquitz Valley, 8,000 ft., San Jacinto Mts., 1; Strawberry Valley, 6,000 ft., San Jacinto Mts., 9.

The Fisher Ground Squirrel is closely related to, and in general very much like, the California Ground Squirrel with which it blends in Kern and Tulare Counties. In general appearance the former is slightly smaller and decidedly paler than the latter. The Fisher Squirrel may be recognized in the field by its extensive white shoulder patches. This sub-species is also known as "digger" squirrel.

The range of the Fisher Squirrel includes Kern Valley and part of Owens Valley, the extreme southern part of the San Joaquin Valley, and a strip of territory alcng the northern and western edges of the 
Mohave Desert from the mountains east of Owens Lake south to the Santa Rosa Mountains west of Salton Sea.

In altitude this squirrel ranges from 450 feet, as at Palm Springs at the eastern base of San Jacinto Peak, to 10,500 feet, as within a quarter of a mile of the summit of the same mountain (H. S. Swarth, MS). It is to be found from the southernmost plains of the San

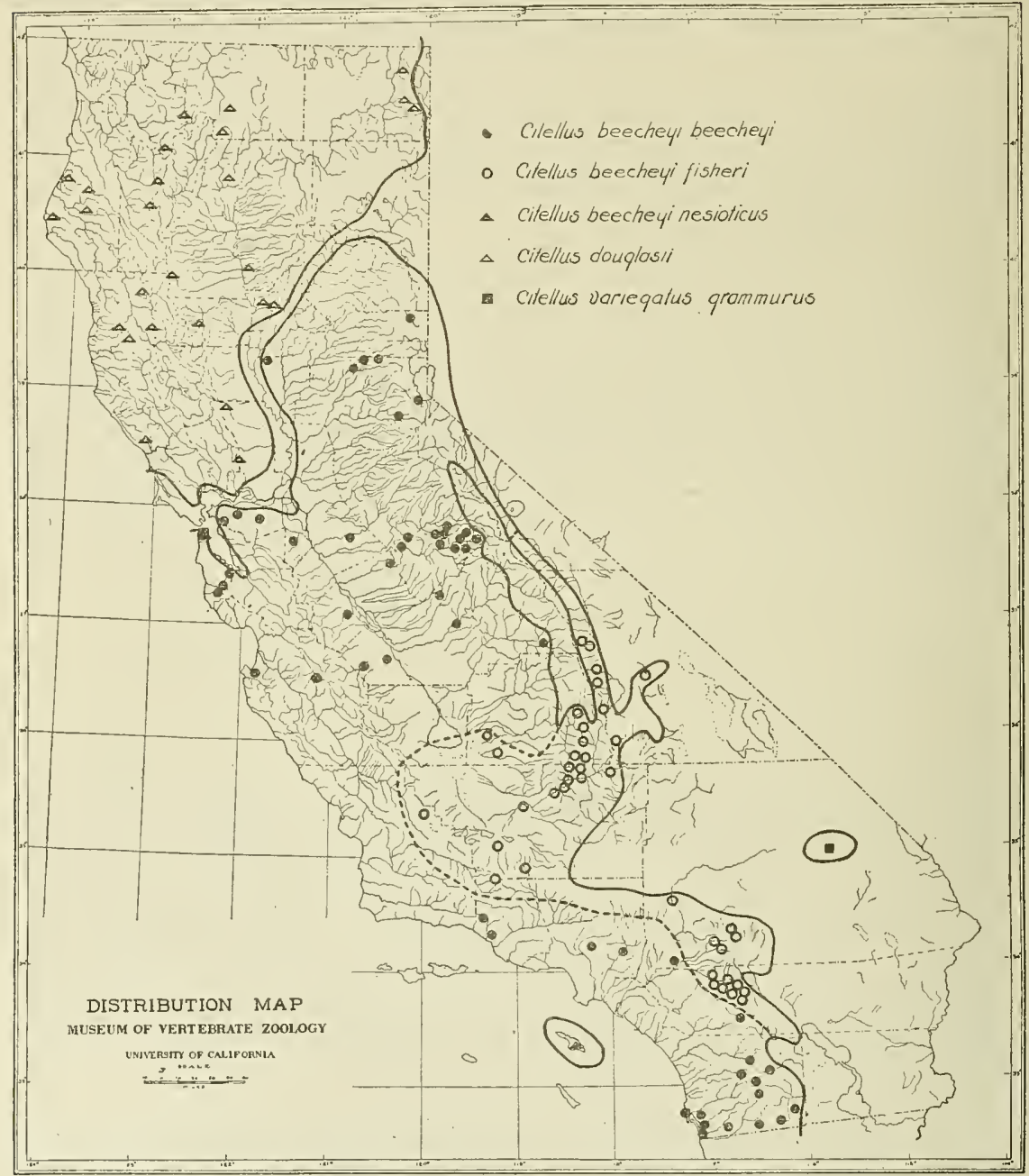

FIG. 17. Map showing California distribution of the California, Fisher, Catalina Island and Douglas ground squirrels, and the Rock Squirrel, all being of the "digger" category. The spots represent localities from which actual specimens have been examined.

Joaquin Valley to 10,000 feet altitude in the Mount Whitney region. This rodent thus shows little regard for zonal limitations, occurring all the way from the Lower Sonoran zone to the Canadian zone, though its numbers above the Upper Sonoran are small. It is equally at home 
in the cultivated fields in the irrigated sections, about Bakersfield and on the rocky ridges of the Panamint Mountains.

At Jackass Springs, in the Panamint Mountains, Inyo County, on October 5, 1918, eight Fisher Ground Squirrels were counted in a threehour census in the belt of sagebrush and piñon. These were invariably perched upright on the summits of gray granite boulders. They were even then notably pale-colored, with beccheyi in mind ( $J$. Grinnell, MS).

At Mount Pinos, Ventura County, during the first week in July, 1904, Fisher Squirrels were present from the very summit (8,826 feet) down. They were trapped among the rockpiles near the top, and on the smooth slopes among the firs on the north side. Young were numerous, and quite unsuspicious, being run down with ease when caught a little ways from their retreats (J. Grinnell, MS).

Near Lone Pine in Owens Valley on June 16, 1917, Fisher Ground Squirrels were found inhabiting the lower embankment of the Los Angeles Aqueduct. At one point three miles south of Lone Pine, some thirty squirrels were noted along the aqueduct in a distance of half a mile. Other colonies were found along Lone Pine Creek at the edge of an old orchard (A. C. Shelton, MS).

In the region about Bakersfield Fisher Squirrels were found in considerable numbers near the mouth of Caliente Creek east of Bakersfield both in the wheat fields and on the adjoining plains covered with a low growth of cactus. In the irrigated region southwest of that city the squirrels were locally numerous on pasture land.

The Fisher Ground Squirrel as far as we can see is indistinguishable from the California Ground Squirrel in many particulars such as behavior", voice and mannerisms. This statement applies also to the general feeding and breeding habits of the form. Nany incidents bearing on such points as enemies and natural checks have been recounted in our chapter relating to beecheyi, since they are for the most part identical in the two races.

Certain instances of behavior in the desert race seem worthy of special mention. At Isabella, Kern County, on July 4, 1911, W. P. Taylor (MS) states that it was a common thing to see the squirrels up from the ground in guatemotes or willows. At Palm Springs, Riverside County, on February 4, 1916, two Fisher Squirrels were seen to leap an irrigation ditch near town, a clear jump of about four feet (H. S. Swarth, MS). Sometimes individuals of this species do not hesitate to jump into water and swim, so as to escape from enemies. At Onyx, Kern County, on June 19, 1911, a half-grown squirrel was surprised on the bank of an irrigation ditch which was full of water. The stream was six feet wide, with rapid current. Without the least hesitation, the squirrel precipitated itself into the water and swam across, reaching the opposite shore by a diagonal down-stream course. It then quickly ran to a burrow, with the location of which it seemed familiar and from which it is likely to have come originally and crossed the ditch of its own accord for the purpose of foraging ( $J$. Grinnell, MS).

The time of birth of the young in this species varies with altitude, more precisely zone, from April to late in June. At Cabezon, Riverside County, a one-third grown young one was secured May 16, 1908, 
while at 8,500 feet on Mount Pinos, Ventura County, a similar sized young one was taken July 11, 1904. At the former locality three juveniles and an adult female were drowned out of one community burrow in an almond orchard. This is probably about the minimum number in a litter, as the average number of young in a litter appears to be only slightly less than in the California Ground Squirrel. "The average number . . . of young at a birth . . . along the borders of the Mohave Desert appears to be ...6 or 7 "' (C. H. Merriam, 1910, p. 4). At Schain's Ranch, San Jacinto Mountains, on June 18, 1908, a family of eight young ground squirrels was observed aboveground at one time at the mouth of a burrow (W. P. Taylor, MS).

Regarding food preferences of this sub-species a special feature has been noted with extraordinary frequency, as follows. Many Fisher Ground Squirrels are taken in meat-baited steel traps set for predatory carnivores under circumstances which make it seem certain that they were caught while trying to steal the bait. They have also been known to eat woodrats and even other individuals of their own kind which they have found dead in traps.

At Kelso Pass, Kern County, on July 8, 1911, two Fisher Ground Squirrels came to drink at a seepage from a spring. One drank six times, the fifth time for over two minutes, by count of seconds ( $J$. Grinnell, MS).

The following records of cheek-pouch contents establish some of the sorts of food taken by this animal. At Taylor Meadow, Tulare County, a squirrel was taken on July 25, 1911, with 88 seeds of a lupine (Lupinus grayi) in its cheek-pouches. Another squirrel taken seven miles above Kernville, Kern County, on June 26, 1911, was carrying a seed of the Digger Pine (Pinus sabiniana); while a third squirrel taken at Lone Pine, Inyo County, had gathered and placed in its cheek pouches 118 seeds of Encelia frutescens and 5 seeds of Hymenoclea salsola.

Squirrels of this subspecies were found doing a large amount of dam. age to the almond crop at Cabezon, Riverside County, on May 16, 1908. Here they were living right in the almond orchard, most of the inhabited burrows being dug close to the roots of the trees. Other short, shallow burrows were noted, but these were thought to be of use only for temporary protection in case the animals were taken by surprise (C. H. Richardson, MS).

In Antelope Valley, near Fairmont, Los Angeles County, on June 22, 1904, the authors found ground squirrels doing enormous damage to almonds, climbing the trees and biting open the green fruit to take out the pit and often leaving the hull in place on the tree. The pit was frequently found to have been removed from a remarkably small hole in the side or end of the shell.

At various points within the range of fisheri we have been told by old residents that digger squirrels have only recently invaded the locality and that a few years ago there were none where many squirrels are now present. In many such cases the sudden increase in the number of ground squirrels is evidently due not to invasion from without, but to the breeding up, under favorable conditions, of the local stock of squirrels which have been present all the time, but which was formerly so 
small and scattered that it did not attract attention. A typical example is as follows.

Residents of Owens Valley at Lone Pine stated in June, 1917, that the ground squirrels there had only recently invaded the valley and that none were known in that vicinity five years before. But from this same locality specimens now preserved in the Field Museum of Natural History in Chicago were obtained in 1902, fifteen years previously. Although the squirrels are said to be steadily increasing along the west side of Owens Valley, little or no effort appears to have been attempted at controlling the pest.

At the Carl Walters Ranch, two miles north of Independence, on June 26, 1917, Fisher Ground Squirrels were found to be fairly abundant on both this and most of the other ranches in the vicinity. They had been considered a nuisance here for a number of years (A. C. Shelton, MS).

The irrigation and cultivation of extensive areas have resulted in a greatly increased available food supply which has proven acceptable to the ground squirrel and has resulted in greatly increasing its population. It is the authors' belief that the squirrels have been present in Owens Valley from time immemorial and that as long as they were few in numbers and stuck to the rocky, uncultivated ground they remained largely unnoticed, but that when they invaded irrigated fields and became numerous they attracted attention and were then thought to have but just moved into the valley.

It is believed that, on the whole, there are only about half as many Fisher Ground Squirrels to the square mile throughout its range as there are California Ground Squirrels to the same unit of area in the range of that form. Fisher Squirrels nevertheless prove very destructive locally to cultivated crops. Many small isolated orchards and "dry-farmed" grain fields are scattered throughout the western and northern parts of the range of fisheri and these frontier ranches are the ones which suffer. While the money value of the crop destroyed may be small, yet such crops are often the settler's principal means of obtaining a livelihood and, although this may be humble indeed, its loss is felt critically. It is the authors' belief that the Fisher Ground Squirrel ranks third, or next after the Oregon Ground Squirrel, in point of economic importance in California.

\section{CATALINA ISLAND GROUND SQUIRREI.}

\section{Citellus beecheyi nesioticus Elliot.} part.

Other names.-Island Spermophile; Citellus nesioticus; Spermophilus beecheyi,

Field characters.- As for the Beechey Ground Squirrel. Only to be distinguished from it on comparison of series of specimens; coloration averaging darker, general size greater, and tail relatively shorter. Length of bod"* alone, "n males, about $11 \frac{1}{4}$ inches; $w^{*}$ th tail (without hairs) about $7 \frac{1}{2}$ inches more.

Description.-Adults in April: Similar to the Beechey Ground Squirrel (San Francisco Bay region) as already described, but general coloration darker; top of head from nose to nape, and broad area down middle of fore back between light 
shoulder patches, deep cinnamon-brown, the hairs individually being black, tipped with cinnamon; middle of back darker in tone than top of head; spot above upper eyelid blackish; cheeks and sides of neck much darker in tone thau in beechevi; whitish shoulder patches, restricted in exten ${ }^{\perp}$, dull and indistinct as compared with fisheri and donglasii, even more so than in beccheyi. Under surface of body very dark in tone, the hairs extensively grayish bister at bases and tipped with cinnamon buff. Tail and feet colored as in beecheyi.

Color variations.-The type and one other specimen show a black patch on the crown, due to lack of cinnamon hair-tippings; this, of course, is merely an individual feature.

The May-taken series at hand shows various transition stages from winter to summer pelage. In most of the specimens the fore parts are in fresh harsh summer coat, while the rump is still covered with the winter coat, showing underfur, and being more or less worn and faded. The tail in some examples is markedly worn and faded, with the usually resulting changes in color. In some specimens the hairs of the tail show but two dark bands instead of three; but this variation occurs also in other near-related races of ground squirrels. The two skins taken in February are in full winter pelage, showing more or less underfur over the whole body and no signs of molt. The fore parts, as compared with the summer pelage, are less bright in color tones, and the shoulder patches are even less distinctly whitish. Hinder upper surface and tail exactly as in beecheyi of same season.

Measurements.-Average and extreme measurements, in millimeters, of nineteen full-grown specimens from near Avalon, Catalina Island, are as follows: Seven males: total length, $471(447-495)$; tail vertebræ, $189(175-200)$; hind foot, 59 (55-63); greatest length of skull, 60.2 (56.1-63.7); zygomatic breadth, 36.9 (33.8-39.2) ; interorbital width, 14.8 (13.3-15.9). Twelve females: total length, 444 $(406-475)$; tail vertebræ, $179(161-194)$; hind foot, 56 (53-62) ; greatest length of skull, 57.T (54.0-62.4); zygomatic breadth, 35.9 (33.3-37.6); interorbital width, $14.3(13.0-15.4)$.

Close examination of the series of skulls shows to us no character by which to tell them from beecheyi or fisheri except for average greater size. There is the usual range of variation in proportions, due to age, this factor being judged from degree of wear on the crowns of the molariform teeth. Old skulls are largest, broadest relatively to length, and with most prominent ridges and processes. It is difficult for us to understand how Elliot (1904, p. 263) could have assigned the numerous cranial characters he did to the form he named, except on the ground that he examined but a very few specimens of beecheyi and fisheri and that these happened to be extreme.

Type locality.-Santa Catalina Island, California (Elliot, 1904, p. 263) ; more exactly, vicinity of Avalon, according to the collector of the type, Mr. John Rowley, in interview.

Distribution area.-Santa Catalina Island, California. Life-zone, Upper Sonoran.

Specimens examined.-A total of 21 skins and skulls, all from the vicinity of Avalon, Catalina Island. Two of these (including the type) were loaned us from the Field Museum of Natural History, Chicago; and nineteen were loaned us from the Museum of History, Science and Art, Los Angeles.

Only three species of rodents are known to be native to Catalina Island, a harvest mouse, a white-footed mouse, and the Catalina Island Ground Squirrel. This last-named animal is, as in each of the other cases, but slightly differentiated from its counterpart on the adjacent mainland. With little doubt it differs no more from its near relative, the Beechey Ground Squirrel, in general habits and traits, than it does in structure.

Until the present year very little has been known of the Catalina Island Ground Squirrel. In fact, the original characterization of the race was so unsatisfactory as to leave doubts in the minds of some students as to whether the island animals really differ at all from the 
mainland ones. Fortunately for the present writers, our appeal to Mr. Frank S. Daggett, Director of the Museum of History, Scienee and Art, in Los Angeles, was promptly met by action, and Mr. L. E. Wyman of Mr. Daggett's staff was detailed to go to Catalina and obtain a sufficient number of specimens for deciding the doubtful questions. Mr. Wyman was eminently successful, and the resulting series of skins and skulls, together with the accompanying information, was freely placed at our disposal for use in connection with the present paper.

Mr. Wyman found the squirrels fairly swarming May 9 to 16,1918 , at the upper end of a narrow tract of bottom land about a mile back of Avalon. This tract, dotted with elderberry trees, had been seeded to barley, and the grain stood knee-deep except in the spots where it had been persistently eaten down by the squirrels. The hillside adjoining on the northwest was steep and fairly well covered with cactus and chaparral, and in places it was honeycombed with burrows. The bottom of the hill was beset with extensive diggings every fifty feet or so.

Besides the barley, the squirrels were feeding on a variety of wild vegetation. Each of the numerous stomachs examined contained a wellchewed green mass. Cheek-pouches were found to contain barley blades and certain seeds, and in one case four bulbs of "sour-grass" or" "grassnuts" (Brodicea capitata), the largest of which was half an inch in greatest diameter. These bulbs seem to be specially sought after, as several small areas were found, usually on south-fronting grassy hillsides, where the ground was all dug up by the animals, and hulls of Brodiæa bulbs were lying about.

One ground squirrel was seen at work in a wild tobacco tree about seven feet from the ground. He had gnawed at the stem near the top until only a shred kept it from dropping. Gnawed shells of chilicothe seeds were also found.

Mr. Wyman believes that the notes and actions of the Catalina Island Ground Squirrel do not differ to any appreciable extent from those of the mainland Beechey. The island animals were perhaps slightly less noisy, though when once started to barking they seemed hardly able to stop. They were found to be shy on open ground, hustling to cover when the invader of their domain was yet 200 yards off. By sitting quietly under a tree, however, Mr. Wyman had one squirrel approach him to within ten yards and feed on barley shoots. On the brushy hillsides, the collector was able to stalk his quarry with ease.

All the females taken were notably fat, and none contained embryos. Also no young of the year were seen; so that it would seem that the breeding season of the island squirrel is much later than that of the mainland animal-later, at least, than May 16. Erery specimen taken by Mr. Wyman was "loaded with fleas;" these, however, quickly disappeared and in no case cansed any annoyance to the collector.

Since ground squirrels were seen by the senior author commonly in August, 1903, in the vicinity of the Isthmus, near the northwest end of Catalina, it may be inferred that the animals are widely distributed over this island. No species of ground squirrel whatever exists native on any of the other California islands. 


\title{
DOUGLAS GROUND SQUIRREL.
}

\section{Citellus douglasii (Richardson).}

\author{
PLATE II.
}

Other names.-Douglas Spermophile; Digger Squirrel, part; Arctomys douglasii; Citellus douglasii; Citellus variegatus douglasii; Spermophilus grammurus douglasii; Spermophilus douglasii; Citellus beecheyi donglasii; Spermophilus grammurus beecheyi, part; Citellus grammurus douglasii.

Field characters.-As for the Beechey Ground Squirrel, from which differs noticeably in the possession of a blackish brown wedge-shaped patch on the fore part of the back; also shoulders more extensively silvery white, and tail longer. Length of body alone, in males about 11 inches, with tail about $S$ inches more.

Description.-Adults in early summer pelage: Crown of head to nose buckthorn brown, becoming mixed with blackish toward eyes and ears; backs of ears deep bister brown margined behind broadly with clay color; insides of ears dull cinnamon-buff; eyelids white; whiskers black; side of head and of body behind shoulder deep bister brown, with much buffy white tippings to hairs; a conspicuous wedge-shaped patch on middle of fore part of back, with apex at nape of neck, solid deep bister brown in color, almost black in some specimens; shonlder patch extensively silvery white, this extending backwards to hinder end of median dark wedge. Hinder portion of body colored as in the Beechey Ground Squirrel, but dappling more conspicuous, due to the whiter tone of the light spots. Under surface of body of darker tone than in beecheyi, seemingly due to the darker, sepia brown, bases of the hairs showing through the dull white or buffy overwash. Feet as in beccheyi but clouded above with dusky. Tail colored as in beccheyi but light tippings to hairs greater in extent and whiter in tone, thus accentuating the white fringe, and producing a grayer effect throughout.

Color variations.- Young but a third grown usually show the characters of the species, both as to color and relative tail length, quite as well as do adults. In one example, however, the black dorsal wedge is considerably obscured by buffy mottlings, and it thus resembles beecheyi of the same age.

The effects of wear and fading rarely bring such extreme modification of color tones in donglasii as in beecheyi and fisheri, possibly due to the lesser intensity of the sunlight and dryness to which their habitat is usually subject. The black wedge on the fore back is most vivid in fresh pelage; in cases where wear and fading have progressed to an extreme degree, the black wedge is much dulled toward brown, and may be effaced almost entirely. The identity of the ground squirrels iu any given locality can be determined with certainty by securing several individuals, when the normal, distinctive coloration is sure to be shown by some of them.

Measurements.-Average and extreme measurements, in millimeters, of seventeen full-grown specimens from the northwestern counties of California (Sonoma to Humboldt) are as follows: Twelve males: total length, 478 (438-504); tail vertebræ, 200 (175-221) ; hind foot, 60 (57-63) ; ear from crown, 23 (19-29) ; greatest leugth of skull, 60.5 (57.8-63.1) ; zygomatic breadth, 37.0 (34.9-38.2); interorbital width, 14.3 (13.5-15.7). Five females: total length, 439 (427-453); tail vertebræ, 192 (161-210) ; hind foot, 57 (56-60) ; ear from crown, 23 (18-26) ; greatest length of skull, 58.5 (56.8-60.4) ; zygomatic breadth, 35.9 (35.0-36.8) ; interorbital width, 14.0 (13.1-15.0).

Always taking age into account, there appear to be fairly diagnostic average skull characters for douglasii as compared with beecheyi, fisheri and nesioticus. Douglasii averages smaller in regard to auditory bullæ, and narrower as regards rostrum and braincase. Yet, as the above measurements show, the gross size of the skull is not especially different.

Type locality.-Probably somewhere in southern Oregon or northern California. The type was a hunter's skin "received from the banks of the Columbia" (Richardson, 1829 , p. 172).

Distribution area in California.-Roughly, the northwestern section of the state, north of San Francisco Bay, west of the lower Sacramento River, and north of a dlagonal line from near Chico northeast to the Nevarla line near the southern 


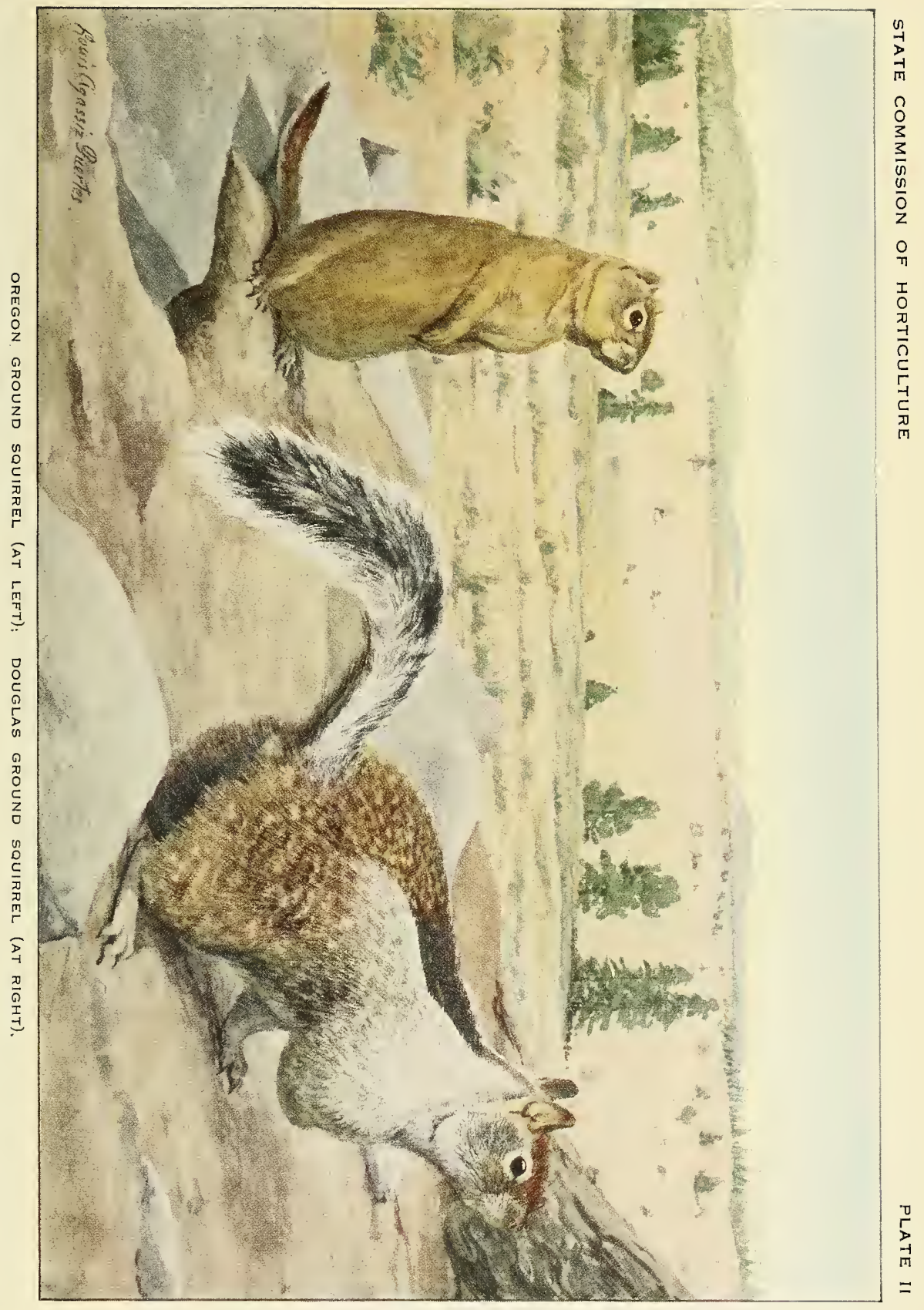



boundary of Modoc County. (See map, fig. 17.) Life-zone, Upper Sonoran and Transition, ranging down into Lower Sonoran along the western side of the Sacramento Valley. Altitudinally, the species ranges from near sea level up to as high as 6,500 feet (near South Yolla Bolly Mountain) and eren 6,500 feet (on. the Scott Mountains, Siskiyou County).

More in detail: The southern limit of the range of douglasii is not known to reach the Golden Gate; it falls, on the sea-coast, somewhere not far to the north of Point Reyes Station, and extends from there to the vicinity of Petaluma, leaving the southern two-thirds of Marin County uninhabited. It extends nearly or quite to Benicia and to the southern end of the range of hills west of Vacaville. The flood-plain of the Sacramento River forms the eastern boundary north to beyond the Marysville Buttes. Thence northeastward, across the Sacramento Valley, there is no obvious barrier. In Butte, Plumas and Lassen Counties the ranges of douglasii and beecheyi approach very closely, but so far as known they do not overlap; nor have undoubted hybrids or geographic intergrades been reported.

Specimens examined.-A total of 65, from the following localities in California : Modoc County: Sugar Hill, 3; Parker Creek, Warner Mts., 3; Deep Creek, Warnel Mts., 1. Siskiyou County: Mayten, 1 ; six miles northwest of Callahan, Scott River Valley, 6; Summerville, 1; Castle Lake, 3. Shasta County: McCloud River, near Baird, 7. Tehama County : Mill Creek, 2 miles northeast of Tehama, 4; four miles south of South Iolla Bolly Mountain, 1. Butte County: four miles southeast of Chico, 4; Dry Creek, on Oroville-Chico road, 3. Glenu County: Winslow, 4. Yolo County: Rumsey, 1. Solano County: three miles west of Vacaville, 2. Humboldt County : Eureka, 1 ; Fair Oaks, 2 ; Ferndale, 1; Cuddeback, 1. Trinity County : Hayfork, 2; Helena, 2. Mendocino County: Sherwood, 3; three miles south of Covelo, 1; six miles north of Willets, 1; Mount Sanhedrin, 3. Sonoma County : seven miles west of Cazadero, 4.

The Douglas Ground Squirrel belongs to the group of large, bushytailed, tall-eared ground squirrels which include the California, Fisher, Catalina Island and Rock Squirrels, and in common with the first and second of these at least it is often called Digger Squirrel. Although the differences are not great, they are evident and should be recognized in economic work, for they not only concern color, but apparently also habitat and food preferences. The Douglas Squirrel differs from its next neighbor of the "digger" category, the California, in having a conspicuous blackish wedge-shaped patch on the middle of the back between the shoulders, in having the shoulder region more extensively grayish white, and in having the tail a little longer and grayer.

The name of the squirrel now under discussion was bestowed upon it (Richardson, 1829, p. 172) in acknowledgment to an early English explorer in western America, David Douglas, for having brought home specimens of the animals met with, many of which proved to be new to science. Donglas's travels carried him through parts of Oregon and probably northern Califormia; but the type of this ground squirrel was a hunter's skin received from the Columbia River. There is no telling now exactly where it really came from originally, though probably from much south of the Columbia, since the species is not known to have existed within history that far north.

In northern California the Douglas Ground Squirrel occupies a wide area; in fact, at the extreme north from the Pacific Ocean to the Nevada line. To the southward its range includes all of the upper Sacramento Valley, and its western half lower down, and the whole coast region (hills and included valleys) south nearly to San Francisco Bay. Reference to the map (fig. 17) will show that the range of the Douglas is almost exactly complementary to that of the Beechey; at no point do 
they overlap, or, indeed, as far as known, quite meet. Roughly, the Douglas Ground Squirrel occupies the northern and northwestern third of the state.

The local or habitat preference of this species is more exclusively for hilly country than in the case of the California Ground Squirrel. It is true that the Douglas exists out on the floor of the Sacramento Valley nearly to the lands annually flooded along the river; but it occurs there interruptedly, in far separated "colonies," and never anywhere are the great numbers reached that characterize beecheyi in the San Joaquin Valley. The preferred haunts of douglasii are the openings or glades on hillsides, beneath scattered oaks or pines, or else the open tracts along stream courses, not, however, quite down to the water's edge. The edges of the smaller valleys between the coast ranges are well populated, but the open floors of these valleys are not often invaded very far or in any considerable numbers. J)ense chaparral and thick woods are avoided altogether.

It is interesting to note here that where the coast redwoods have been lumbered out the Douglas Ground Squirrels have come in from the interior so as to be plentiful where formerly scarce or wanting. Chaparral slopes which have been swept by fire are also quickly invaded and occupied for a time, until the brush grows up thickly again. It is probable that the squirrels are unable to maintain themselves against enemies, such as bobcats, that habitually hunt by stealth through underbrush; the squirrels require a certain amount of space around them so that they can have a fair show of reaching the safety of their burrows after an enemy is first caught sight of. Even though the Douglas Ground Squirrels are nowhere so very numerous as compared with certain other rodents, their predilection for clearings brings them into economic prominence locally. We have been told repeatedly of cases where newly cleared farms in mountain valleys have been invaded at harvest time from the nearby hillsides, to the almost complete loss of the crops.

It is a curious thing that the Douglas Ground Squirrel should not occur south clear to the shores of San Franciseo Bay, inasmuch as the Beechey on the south side of the bay extends up to either the very shore line itself or to the margin of the salt marshes adjacent, or did so until very recent year's This may be merely another indication of the lesser degree of aggressiveness or prolifieness on the part of the Douglas Squirrel. Marin County seems to be devoid of any ground squirrels whatsoever, except for a few douglasii along the Sonoma County border. Joseph Mailliard (interviewed on May 8, 1918) states that in his forty years or more of residence in Marin County, he never saw any ground squirrels in the southern part or westwardly towards Point Reyes. Individnals were seen twice many years ago on the Rancho San Geronimo, but "they never stayed." To all appearances the conditions here are identical with those in the Russian River district and a few miles west of Petaluma where the animals in question are plentiful, or used to be until successfully combated.

Within the California portion of its range the Douglas Ground Squirrels are believed to be most numerous in Tehama County, this according to the consensus of opinion in the office of the State Superintendent of Rodent Control. In Shasta County, next on the north, there are rela- 
tively few. To the westward they extend within a mile of the seacoast in the vicinity of Eureka and at Cape Mendocino, but elsewhere mostly not closer to the sea than eight or ten miles. Nowhere in the immediate coast belt are they reported especially numerous or injurious. Pocket gophers there loom up as the most destructive rodent.

The voice and mannerisms of the Douglas Ground Squirrel are not to us in any points that can be remembered materially different from those of the California Ground Squirrel. A fair test of this could, of course, only be made upon the two if studied side by side under perfectly normal conditions. In the nature of the case this is impossible, for in no known locality do they occupy common ground.

The tail is at all times the most conspicuous feature of this ground squirrel. Sometimes when running to its burrow a squirrel will hold its tail in a continuously vertical position, or this member may be thrashed fore and aft. Ordinarily the tail is held nearly parallel to the ground, with more or less of an arch in it. In this posture of tail one is reminded strongly of the Gray Squirrel.

Our own observations, and the testimony of people in general who are familiar with several of our ground squirrels including the Douglas, indicate that the latter is the most prone of all to climb trees. For instance, near Tehama, June 8, 1912, several individuals were seen well up in large white oaks (W. P. Taylor, MS). At Winslow, Glenn County, June 19, 1912, one was seen in a buckeye, and several from twelve to fifteen feet above the ground in willows and cottonwoods (W. P. Taylor, MS). At Sisson, Siskiyou County, August 11, 1914, one was seen thirty feet above the ground in an incense cedar ( $T$. I. Storer, MS). It is a common thing to see them perched upon the tops of fence posts or stumps. Individuals may under certain circumstances so nearly resemble Gray Squirrels as to be actually mistaken for them. This emphasis of the tree-climbing habit in the Douglas Ground Squirrel is, suggestively enough, thus associated with greater length of tail and grayer tone of color of tail, as compared with its nearest relatives. It seems, also, that this species, more generally than any other, raids orchard trees such as almond and apricot.

The sure test, on the basis of behavior, of a ground squirrel as compared with any true tree squirrel, such as the California Gray, is that the former, no matter how high in a tree when discovered, will, upon alarm, take to the ground as quickly as possible, and seek safety in a burrow below ground, rather than make off through the branches from tree to tree, or ascend into the uppermost foliage of a treetop. Not infrequently, when surprised in a tree, a ground squirrel will for the time being "freeze" and attempt to escape being" seen by remaining motionless. But after being further disturbed and once starting, he makes for the ground by the shortest route.

The burrowing habits of the Douglas Squirrel are similar to those of related species. Steep banks seem to be chosen for burrowing into, whenever available. Many burrows open under rocks, bushes and tree roots. On open, level ground, with no protective shelter at hand, the mouths of the burlows are marken by good-sized mounds, showing the presence of an extensive system below ground. As far as we know, no one has yet made a complete excavation of the burrow system of this species. 
The breeding season is indicated by the time of appearance of the young aboveground. In Scott Valley, Siskiyou County, where the species is abundant, very small young were seen abroad on June 8 (1911). At Winslow, Glenn County, young one-fourth to one-half grown were captured on June 16 (1912). At 6,800 feet altitude on the Saloon Creek Divide, in the Scott Mountains, Siskiyou County, July 10 (1911), nursing females were captured, but no young were yet out (L. Kellogg, MS). It is thus probable that at the lower altitudes the young are born during the last half of May, while at the highest levels they are not born until at least a month later. Only one litter is reared each year.

Unfortunately we have no facts of our own to offer in regard to size of litter. We have an idea that fewer young are born each year than in the case of the California Ground Squirrel, judging roughly from the numbers of young seen aboveground, about five. But this is almost pure conjecture. F. E. Garlough, of the Unifed States Biological Survey, is under the impression (interviewed September 7, 1918) that litters in the lowlands average close to eight, while in the mountains five is the usual number. He has known of as few as two and as many as fourteen embryos having been found in pregnant females.

The following definite data on file in the Museum of Vertebrate Zoology show some of the kinds of food selected by the Douglas Ground Squirrel and also the quantity in which each of these kinds may be gathered at one time. A male squirrel taken on Dry Creek where crossed by the Oroville-Chico road, in Butte County, May 31, 1912, contained in its cheek pouches 29 seeds of a wild lupine (Lupinus micranthus). Three others taken on Butte Creek, near Chico, June 3 and 5, 1912, contained in their cheek pouches materials as follows: male, 12 seeds of milk thistle (Silybum marianum); female, 219 grains of barley and one head of English plantain (Plantago lanceolato); female, 142 grains of barley. The cheek-pouch contents of two squirrels taken on Mill Creek, near Tehama, June 12, 1912, consisted of, respectively : female, 121 seeds of bur clover (Medicago hispida) and 70 small unidentified seeds, part loose and part in three whole pods; female, 181 seeds of brome-grass (Bromus carinatus) and one piece of an acorn. Two squirrels taken in the hills three miles west of Vacaville, July 3 and 6,1912 , contained in their cheek-pouches: female, 29 seeds of Napa thistle (Centaurea melitensis) and 30 seeds of bur clover; male, 82 seeds of bur clover, 4 seeds of Napa thistle and one cherry pit. A male taken three miles south of Covelo, Mendocino County, July 20, 1913, held in its cheek-pouches 14 whole fruits and 103 separate seeds of the common manzanita (Arctostaphylos manzanita), as also a few small unidentified seeds of two kinds.

From all sources comes the testimony that this species takes barley and wheat with particular avidity. Its storage propensities are highly developed, and it would be interesting to see actual figures as to the quantity of grain garnered underground in one autumn season. Where they invade apricot orchards, as in the foothill district of the Warner Mountains near Alturas, these squirrels climb the trees and take out the pits, discarding the pulp of the fruit. 
The Douglas, as is known of most other ground squirrels, is fond of flesh when this can be obtained. Many have been taken in the meatbaited steel traps kept out in various localities for carnivores.

Hibernation seems to be more prevalent with douglasii than with beecheyi, for all of the population of the former is reported to disappear for weeks at a time, even in the lower valleys. At the higher altitudes, where there is more or less heavy snow, all the squirrels disappear over a period of some months. In Hayfork Valley, Trinity County, the senior author was assured by several different people living there that the Douglas Squirrels hibernate regularly and completely "from November till April." The earliest spring record we have for a mountainous region is of one squirrel caught in a box trap February 25 (1911) near Helena, Trinity County (A. M. Alexander, MS).

The natural enemies of this squirrel probably include practically all those already specified in our chapter on the California Ground Squirrel. Only one specific instance is at hand. A gopher snake found run over in a road near Chico, June 7, 1912, was found to contain in its stomach a young Douglas Ground Squirrel (T. I. Storer, MSS). Coyotes are locally reputed to levy considerable toll upon this rodent. We have heard the argument advanced against the poisoning of ground squirrels on wild mountain land in the northwest coast district that reducing the squirrel population will deprive the coyote of one of his chief sources of subsistence and that he will thereupon be forced to seek food elsewhere and so be more prone to raid the poultry of the valley ranches and the flocks of sheep in the mountains. On the other hand, it may be advanced that the total coyote population is adjusted to the total amount of food available at the season of least supply, and that removal of any one important kind of food will in course of time reduce the total coyote population able to exist in any general territory.

A high natural mortality for this species may account for its relative lack of aggressiveness as compared with the California Ground Squirrel. The testimony of a number of people from localities widely scattered over the range of the Douglas Ground Squirrel is to the effect that every few years there is a great reduction in its numbers. Some fairly close observers, forest rangers in the Trinity region, for instance, think this is due to the effects of severe winter weather, as when there is an exceptionally heavy snowfall or torrential rains of unusual amount. In either case the squirrels are thought to be drowned in large proportion when lying dormant underground. Other persons think there are recurrent epidemics of some disease fatal to the ground squirrels. We have no.good evidence bearing upon either hypothesis.

Because of this observed reduction in numbers during some winters, certain ranchers have objected to carrying on poisoning operations in the fall, since their efforts might prove to have been unnecessary. They prefer to deal with the naturally rednced squirrel population of the springtime, at the close of the dormant period.

The general range of the Douglas Ground Squirrel has not changed within history as far as definite records show. But, locally, there have been marked fluctuations. On the western side of the Sacramento Valley the animals have been almost completely cleaned out on many large tracts as a result of systematic poisoning. This is particularly true, as we are assured by W. C. Jacobsen, State Superintendent of 
Rodent Control, of the Davis, Williams, Willows and Orland districts. The reason for this is twofold: The Douglas Squirrels never did have a secure foothold in the Sacramento Valley, such as the Beechey Squirrels have in the San Joaquin Valley; and the former, according to current impression, takes the poisoned grain more readily.

On the other hand, with the clearing of forest lands in the coast district, through lumbering and homesteading, the squirrels are thought to have extended their confines locally. At any rate, they have become numerous where formerly absent altogether or present in such small numbers as to have been overlooked by the average person.

In certain sequestered valleys among the northern coast ranges we have been assured of a loss to grain crops, where no effort at poisoning the squirrels had been made, of from 5 to 25 per cent. In such cases the squirrel population from the wild land immediately adjacent seemed to have moved in en masse, as harvest time approached, to take advantage of the special food supply thus made available. Nevertheless, the Douglas Ground Squirrel, by reason of its relatively sparse population over most of its range, and the ease with which it can be reduced in numbers with reasonable effort, does not rank as of so much economic importance as some other species. We would place it fourth among our ground squirrels, giving precedence to the California, Oregon and Fisher.

\section{ROCK SQUIRREL.}

\section{Citellus variegatus grammurus (Say).}

Other names.-Plateau Groind Squirrel; Rocky Mountain Ground Squirrel; Citellus grammurus.

Field characters.-As for the Beechey Ground Squirrel, differing in longer tail and grayer general coloration; fore parts of body continuously grayish white, without specially set-off shoulder patches. Length of body alone abont $10 \frac{1}{2}$ inches, with tail about 8 inches more.

Description.-Summer pelage: Head dull buckthorn brown, grizzled on cheeks and sides of snout; eyelids dull white; whiskers black; backs of ears dull buffy brown, insides of ears pinkish buff. Forward half of upper surface of body light gray, with decided dusky mottling in transverse trend; hinder half of upper surface, of a tawnyolive tone, lighter on sides, and with similar transverse mottling. Whole lower surface of body and upper surfaces of feet, pale pinkish buff, nearly white in some specimens; belly with grayish bases of hairs showing through. Tail considerably bushier than in beecheyi, as well as being longer; length of hairs up to $50 \mathrm{~mm}$. (2 inches); tips of hairs more extensively white, thus nearly as in douglasii; dark and light intervals on individual hairs same as in beecheyi, that is, three dark and four light, the latter including the tipping.

Color variations. - Wear and exposure to intense sunshine evidently accounts for the yellowing of the pelage of one specimen at hand; also the tail of the animal shows a curious crinkling of the hairs as if scorched. An adult of date June 2 has the forward half of the body in fresh new (summer) pelage; this is relatively harsh in texture, without underfur. Young less than balf grown are colored almost exactly as described above for adults, but the pelage on the under surface is very scanty, so that the bare skin shows through extensively. No winter specimens are at hand from within the state of California.

Measurements.-Only two adult specimens are available from California. These are from the Providence Mountains, eastern San Bernardino County, and show meas- 
urements, in millimeters, as follows: Male and female (nos. 117301 and 117300, respectively, Biol. Surv. coll., U. S. Nat. Mus.) : Total length, 470, 465 ; tail vertebræ, 194, 205; hind foot, 58, 54; ear from crown, 20, 21 ; greatest length of skull, 61.2, 58.4 ; zygomatic breadth, 38.5, 37.0; interorbital width, 15.4, 14.2.

No skull differences of crucial importance between grammurus and beecheyi are apparent to us in the material at hand for study.

Type locality.-Purgatory River, near mouth of Chacuaco Creek, Las Animas County, Colorado (according to Cary, 1911, p. S7). This form was originally described by Thomas Say in 1823.

Distribution (in California).- Inhabits the Providence Mountains, in eastern San Bernardino County (see fig. 17) ; also "the canyons of the Colorado River" (Merriam, 1910, p. 2). Life-zone chiefly Upper Sonoran.

Specimens examined from California.-A total cf five, all collecled by Frank Stephens, June 1 to 3, 1902, in the Providence Mountains, 5,000 to 5,500 feet altitude. These were loaned us from the Biological Survey collection, United States National Museum.

The Rock Squirrel is really a very close relative of the Beechey Ground Squirrel and its habits are doubtless closely similar. It is a wide-ranging form through the southern Rocky Mountain region, stations of occurrence in southeastern California being merely far western outposts. Two of the specimens from the Providence Mountains are young less than half grown; these were taken on June 1 , and indicate a breeding date at about the same time of year as for other ground squirrels in the upper Sonoran zone.

\title{
OREGON GROUND SQUIRREL.
}

\section{Citellus oregonus (Merriam).}

\author{
PLATE II.
}

Other names.-Oregon Spermophile ; Bull Dog ; Prairie Dog, part; Gopher; Bobby ; Sand Rat; Short-tail; Woodchuck; Belding Ground Squirrel, part; Picket-pin, part; Spermophilus oregonus; Citellus beldingi, part; Spermophilus richardsoni.

Field characters.-A medium sized, short-tailed ground squirrel, of stocky build, and of brownish gray coloration without special stripes or markings of any sort (see fig. 20a). Length of body alone about $8 \frac{1}{2}$ inches, with tail about $2 \frac{1}{2}$ inches more.

Description.-Adult in slightly worn spring pelage: Whole upper surface of a general drab tone of coloration, tinged with cream-buff along sides and with dull cinnamon on top of head and down middle of back. There is usually a faint pattern of fine dappling. Eyelids dull white; whiskers black; ears clothed with short bairs, like top of head in color. Upper surfaces of feet tinged with warm buff; palms naked ; soles naked except for sparse hairing forward from heel nearly to tubersles; claws horn-color, dusky at bases. Tail full-hailed, flattish, widest about oue-fourth way back from end; color on upper surface mostly like back, except for showing through of the hazel bases of the hairs, and for black zone about end succeeded by a buffy white fringe; under surface of tail bright cinnamon rufous, with a broad band of black at end and continuing backwards a little ways along either side, and the whole margined narrowly with buffy white. Under surface of body dull cream-buff, paling on throat and inner sides of legs; much brownish lead-color of the hair-bases shows through on abdomen.

Color variations. - As wear proceeds toward an extreme the whole coat becomes grayer, and the cream-buff tints tend to disappear by fading. Males usually remain much less worn than females; otherwise we can see no differences in coloration between the sexes. The material we have shows evidence of lut one molt each year, 
this beginning about July 1st; but we have no specimens of dates between August and May. It is possible that there is an autumn molt leading into a distinct winter coat. Small young are softer-pelaged than adults, but colored just the same.

Measurements.-Average and extreme measurements, in millimeters, of nineteen mature specimens from northeastern California are as follows: Nine males: total length, $275(260-300)$; tail vertebræ, $65(56-80)$; hind foot, 42 (37-45); ear from crown, 9 (7-11) ; greatest length of skull, 45.1 (44.2-46.5) ; zygomatic breadth, 29.1 (27.1-31.0) ; interorbital width, 10.4 (10.0-11.1). Ten females; total length, 280 (271-292) ; tail vertebræ, 57 (47-68) ; hind foot, 43 (41-44); ear from crown, 7.5 (6-8); greatest length of skull, 45.7 (44.9-47.2); zygomatic breadth, 29.7 (29.1-30.4); interorbital width, $10.4(9.7-10.9)$.

From the above figures it would seem that, in this ground squirrel, females are larger than males, except for tail and ear. There are chances, however, that measurement of greater numbers would give somewhat different results. It must be kept in mind that the figures taken from the freshly killed animals were supplied by several different people, and method of securing each measurement undoubtedly varies somewhat with the persons doing the measuring. Even with the skulls, all measured by the senior author of this paper, size clearly varies to some degree with age, and the proportions present in our series, of animals of different ages, will naturally affect the average.

Weights.-Average and extreme weights, in grams, of six full grown females are: $302(267-365.8)$. This average in ounces is about $10 \frac{1}{2}$. The heaviest example was notably fat, the lightest, lean. Adipose tissue thus counts importantly in weight, though probably also weight increases, as does size of skull, with age. The animals would probably weigh most just prior to hibernation, as they are then fattest.

Type locality.-Swan Lake Valley, Klamath Basin [Klamath County], Oregon (Merriam, 1898, p. 69).

Distribution (in California).-Occupies the northeastern corner of the state, comprising the counties of Modoc, Lassen, eastern Siskiyou, and a portion of Plumas (see fig. 18). The metropolis of the species lies in the Upper Sonoran life-zone, but the animals extend through Transition, and even enter the Canadian. In detail: west from the Nevada line as far as the vicinity of Goose Nest Mountain, Siskiyou County, and vicinity of Big Meadows, in extreme northern Plumas County; south from the Oregon line to the last named locality and to the valley of Susan Creek, in Lassen County. Altitudinally, this ground squirrel extends from as low as 3,300 feet, on the Pit River, up to 9,000 feet, on Warren Peak, Warner Mountains (Mus. Vert. Zool.).

Specimens examined.-A total of 51 from the following localities in California: Modoc County: Sugar Hill, 4; Goose Lake near Davis Creek, 2; South Fork Pit River near Alturas, 3; Warner Mts. (Parker Creek and Squaw Peak), 6. Siskiyou County : near head of Little Shasta River, north of Goose Nest Mt., 1; Bull Meadow, northeast of Goose Nest Mt., 1; seven miles south of Macdoel, 24; Grass Lake, 6. Lassen County: Termo, 1; west end of Horse Lake, 1 ; fifteen miles west of Westwood, 1. Plumas County: ten miles west of Big Meadows, 1.

The Oregon Ground Squirrel occurs in California only in the extreme northeastern counties of the state; but it has a rather wide general range which includes much of Oregon east of the Cascades, and parts of northern Nevada. It is a Great Basin plateau species, and its range ends to the westward in California rather abruptly in the vicinity of Goose Nest Mountain (head of Little Shasta River and Grass Lake) and in the Pit River Valley in the vicinity of Burney, Shasta County. To the southward it extends to Big Meadows, in Plumas County a little southeast of Mount Lassen, and to the valley of Susan River, in Lassen County.

In most of the sagebrush territory thus bounded, the Oregon Ground Squirrel is conspicuously abundant, more so, some people believe, than any other species anywhere in this state. While not so large as the 


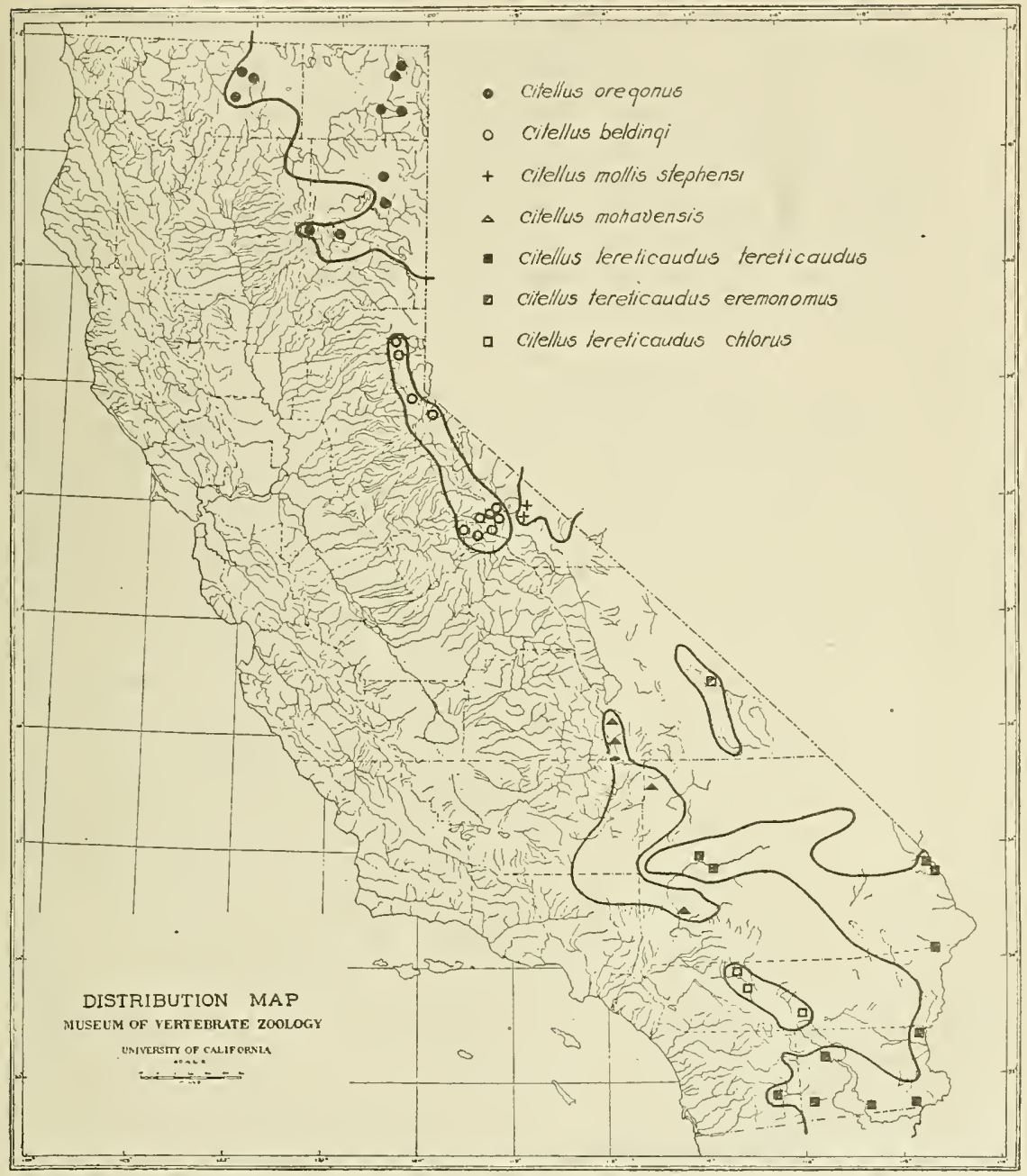

Frg. 18. Map showing California distribution of the Oregon, Belding, Stephens Soft-haired, Mohave, Yuma Round-tailed, Death Valley Round-tailed and Palm Springs Round-tailed ground squirrels. The spots represent localities from which actual specimens have been examined.

Beechey Ground Squirrel individually, it exceeds that species in numbers. At any rate, it ranks highest in importance among rodent pests within its domain.

The Oregon Ground Squirrel is an inhabitant chiefly of mountain meadows and the borders of the bigger meadows of the valleys. It does not care for marshy ground, and it avoids thick brush and rocky slopes. In a way, it is complementary in habitat to the Douglas Ground Squirrel, which occurs in much of the same territory; rarely are the two seen on common ground. It is obviously because of its preference for grass land that the Oregon Ground Squirrel has come so seriously 
into conflict with man's interests. Extensive clearing of the sagebrush and seeding of these clearings to grain and hay has doubtless benefited the squirrels. Indeed, this is likely one of the factors that accounts for their increase of late years as testified to by several of the old-time residents whom we have interviewed.

In Butte Valley, Siskiyou County, the Oregon Ground Squirrels are popularly known as "bull dogs," in Modoc County as "short-tails" (evidently as distinguished from the longer tailed Douglas Ground Squirrel), and elsewhere, locally, as "bobbies," "prairie dogs," "gophers," and "woodchucks." The last three names, of course, are misapplications of names properly belonging to quite different kinds of rodents.

In the latter part of May, 1918, the senior author accompanied Mr. W. C. Jacobsen, State Superintendent of Rodent Control, in a tour through northeastern California for the particular purpose of studying the Oregon Ground Squirrel. In traveling eastward from Shasta Valley, we first encountered this species toward the head of the Little Shasta River, on the Mills ranch at about 4,200 feet altitude. Here we found a field of vetch to be riddled with the burrows and secured one of the animals to verify this, the westernmost record station for the species. At Bull Meadows, a little east of Goose Nest Mountain, the squirrels were exceedingly numerous on the uncultivated open ground among scattering lodgepole pines. Subsequently we found them plentiful around the margins of Grass Lake, nearly as far west, but due south of Goose Nest. But it was on the floor of Butte Valley, from the vicinity of Bray north to Dorris, wherever there were open grass lands, that the Oregon Ground Squirrels simply swarmed. The following observations made May 16, 1918, on a ranch seven miles south of Macdoel, will give an idea of the abundance of the animals where conditions are most favorable to them.

Taking a position at the right-angled intersection of two fences, the observer counted the animals in the quarter-circle gaze thus bounded and found that there were sixty-five squirrels in plain sight within a distance of one hundred yards of him. This was about nine 0 'clock in the forenoon of a bright day, when the squirrels were at about the height of their daily activity aboveground. Young of the year were included.

Again, three adjacent plots of pasture were paced off, thirty-nine paces square, and the open burrows counted. In one plot there were 151 , in the second 182, in the third 194, an average of 176 . This, figured out, makes 560 open burrows to the acre! If we allot one adult squirrel to each five openings, which our observations showed to be about the proper ratio, there would be 112 adults to the acre, not counting young. Figuring, further, this would make somewhat over 70,000 squirrels per square mile! This, however, would pertain only in limited areas and to those pasture lands where little effort had yet been. made to reduce the pests. The population of the sagebrush plains and pine woods of Butte Valley would be much smaller. It is, of course, the pasture lands and grainfields where the squirrels come into chief conflict with man's interests, and this is where they are most abundant. Some further estimates in this connection are likely to prove worth while. 
The average weight of six adult female Oregon Ground Squirrels was found to be 302 grams (about $10 \frac{1}{2}$ ounces). The full stomachs of these six squirrels were found to give an average weight of 18.5 grams. Subtracting the ascertained weight of the stomach itself (3.5 grams), gives the weight of the contents, alone, representing doubtless one full meal, as 15 grams, or one-twentieth the entire weight of the animal. The stomach contents was in all cases a closely packed, slightly moist (not watery) mass of finely chewed green stuff. This could not be analyzed as to kinds of plants represented, but the squirrels were seen to be feeding upon all sorts of vegetation, practically everything going to make up the usual forage grazed from such lands by live stock.

Our observations led us to believe that, at the very least, two full stomach-loads of greens were eaten by each squirrel each day, or 30 grams of forage. Of course this does not account for wastage, evidence of which, in the way of cut stems and grass blades, was plentiful. Figuring from the average number of adult squirrels per square mile, 70,000 , and counting on two meals per day, we find a minimum of $2,100,000$ grams, or somewhat more than two tons, of green forage devoured by the squirrels each day on a square mile of pasture. Granted that a grazing steer eats fifty pounds of pasture forage each day, we conclude that the squirrels on a square mile of pasture appropriate each day the forage which might support ninety head of cattle.

Expressing it in other ways, 750 Oregon Ground Squirrels during the growing season of pasture grass eat as much as one steer, and the squirrels on every seven acres of pasture thickly inhabited by them eat as much as one steer!

The burrows of the Oregon Ground Squirrel where the animals are at all numerous fairly riddle the ground. Most of the openings come to the surface at a rather steep angle and without any earth at their mouths. Now and then there is an opening which slants to the surface and has a good-sized mound, and such as these seem to mark the nesting burrows as distinguished from the short, temporary, refuge burrows, or those occupied by males. We spent the entire day of May 16 excavating one nesting burrow, with results shown in figure 19.

The mound at the main entrance to this burrow system was rather large in extent, though shallow. It consisted of this year's loosely piled earth, covering up the grass on an area of nearly two square yards and thus marking the place conspicuously. The system of burrows, in part at least, probably represented two seasons' work and maybe more. While there were only two openings to this system, there were several points at which underground branches came nearly to the surface so that a hard-pressed squirrel, pursued by some underground enemy, could have quickly dug clear out and escaped overland.

As usual with ground squirrels, the runways were everywhere smooth and free from excrement, the nest ehamber in use being unexpectedly clean. The feces of the young are evidently collected by the mother and carried to the places where her own are deposited, in the special branches or defecatoria. Here the earth is tamped over the mass in such a way that the pellets are kept separated by the soil particles, with no chance to fester. The fecal pellets are dryish, anyway. Some saved for examination, probably from the adult squirrel, prove to be 


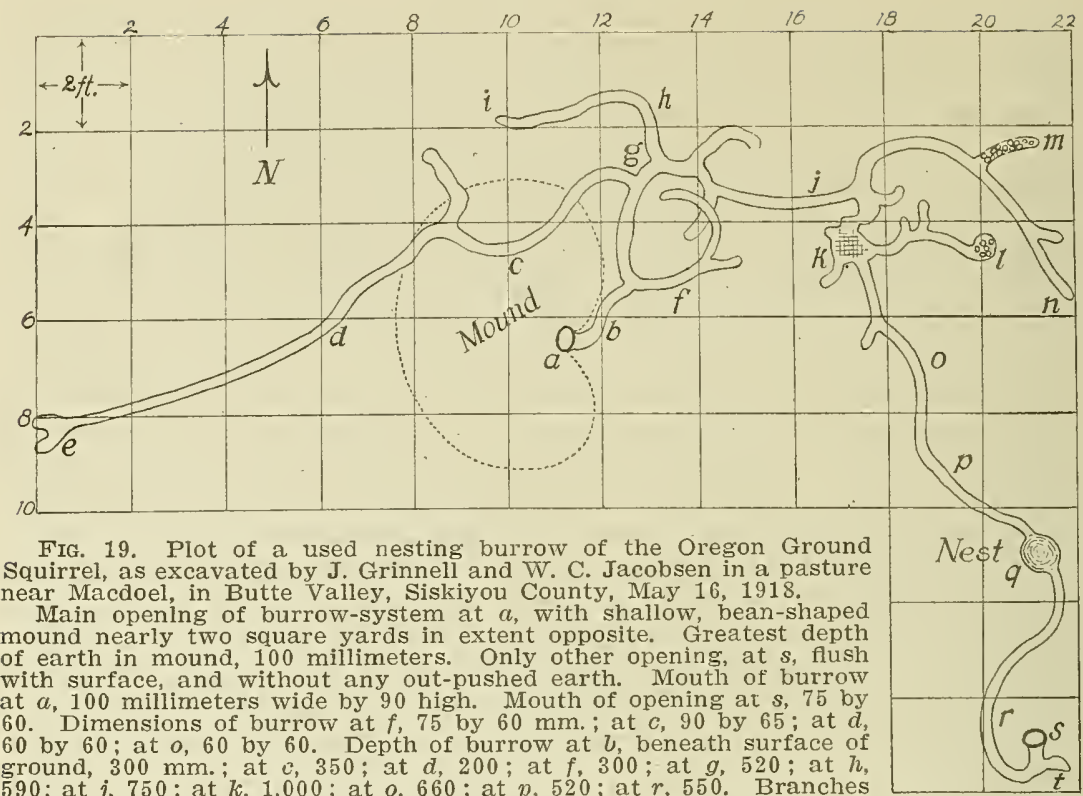
$590^{\circ}$ at $j, 750^{\circ}$ at $k, 1,000$; at $0,660^{\circ}$ at $p, 5200^{\circ}$ at $r, 550$. Branches at $i, e$ and $t$ came nearly to surface of ground. Old nest cavity at $k, 300 \mathrm{~mm}$. in diameter, and floored with a damp mixed mass of old frazzled grasses, excrement, and earth. At $m$ and $l$, chambers, 770 and $1,110 \mathrm{~mm}$., respectively, beneath surface of ground, packed full of a mixture of excremental pellets and loose earth. Blind terminal at $n, 850 \mathrm{~mm}$. deep. New nest, in use, containing many live fleas, at $q$; cavity of this, $190 \mathrm{~mm}$. wide by $170 \mathrm{high}$, and $700 \mathrm{~mm}$. beneath surface of ground, nearly filled with a dry clean hollow mass of shredded juniper bark and weathered grasses. The excavating was begun at $a$, and the female and six third-grown young were overtaken at $s$ and $t$, where they were about to escape.

Total length of this burrow system, 66 feet. Average diameter of burrow, 23 inches. Volumetric content of entire system, $3 \frac{1}{2}$ cubic feet. Greatest depth reached, 45 inches, or nearly 4 feet.

short-cylindrical or elliptical in shape, and measure 6.5 millimeters in diameter by from 15 to 22 in length.

There were two nest cavities in the system unearthed, an old one, and the one in use. The latter contained a dry, hollow mass of frazzled juniper bark and weathered stems and blades of grass. The female parent and six third-grown young were overtaken farther along in the burrow system, near one terminus of it, but that the nest had but recently been vacated was shown by its feeling of warmth to the touch and the presence of numerous lively fleas. The female proved a tartar in defense of herself and young, biting effectively with her sharp incisor teeth and scratching with her strong claws. This was as a final recourse, however, as the first endeavor on the part of all the occupants, when the burrow was opened up, was to escape and run to the nearest shelter, such as offered by some neighboring burrow, or by a flat rock. As far as our observations went, there was no indication that the adult male lives in the same burrow with the female, or has, indeed, anything to do with the rearing of the young.

The burrow system in question was found to be 66 feet long, including the various windings and all of its branches. Its average diameter was about $2 \frac{1}{2}$ inches, and the volume, or cubical air content, $3 \frac{1}{2}$ cubic 
feet. The greatest depth reached beneath the surface of the ground was 45 inches. This was in rather dry pasture, and there was no sign of a water-table; the soil to this depth was only moderately damp.

The notes of the Oregon Ground Squirrel are of two sorts. The most impressive consists of a series of from 8 to 12 shrill, high-pitched calls, uttered in rapid succession-seep, seep, seep, seep, seep, seep, seep, seep, seep. The tendency is to weaken on the last few syllables, but the same pitch is nearly or quite maintained throughout. This call seems to be uttered only by adults, and seems to signify alarm at the first, or distant, approach of danger. One hears it taken up here and there all over a large meadow when it is first entered. Then there is a single shrill chirp of somewhat lower pitch, uttered now and then by either old or young. At times one will hear scarcely a note for many minutes, even when many of the squirrels are in sight, and then again the calls will be given back and forth from all sides.

One old female watched from a distance of 20 feet stood stock still for several minutes at the mouth of her burrow, in upright, "picketpin" fashion. The fore feet she held against her stomach in front. When she gave the several syllabled call she opened her mouth very wide, depressing the tongue on to the floor of her mouth so that it could not be seen, and uttered the successive notes with much appearance of effort. The convulsive movements of the body were synchronous with the notes as uttered. The picket-pin attitude is really not so frequent as a crouching one, though when it is assumed it renders the squirrel visible a long way, especially where the grass is short. When feeding, the squirrel hunches over on its haunches, and uses both front feet and the fingers of these for holding and manipulating the food. When foraging the squirrels do much slinking along, with body horizontal and seemingly touching the ground. When a general alarm is sounded one sees them running in every direction, with a rather clumsy and not rapid, hopping gait. When so lunning the tail, short and never conspicuous, is held either out straight behind or raised at an angle of 30 degrees. Often when halting, or coming to a stand on the alert, the tail is twitched up from the horizontal several times in rapid succession, the whole body also twitching at the same time.

Rarely does an Oregon Ground Squirrel leave the ground, even to climb onto a rock or log. The body is relatively heavy and the general movements are far from nimble. In just one instance was a squirrel observed to have actually climbed; one individual was seen at Sugar Hill, Modoc County, up in a bush four feet above the ground (W. P. Taylor, MS). Marshes or very wet meadows are avoided; in other words, this species does not take to water. Still, we have the one instance of an individual, near Canby, Modoc County, seen (W. C. Jacobsen, MS) swimming across the Pit River. The current here was sluggish and the channel about eighteen feet wide. The act was to all appearances voluntary.

At the season of our special observations, the middle of May, the Oregon Ground Squirrcls were seen to be feeding on practically every sort of pasture vegetation. Cuttings of meadow grass, blades and stems of grain, and leaves and stems of alfalfa were seen on their mounds or in the mouths of their buriows. As already stated, determination of 
the kinds of plants eaten, from stomach examination, proved impracticable because the food is chewed so finely. Even young less than a third grown were feeding freely on green stuff. Six young taken on May 16 were found to weigh from 65.1 to 104.7 grams, averaging 82.4 grams as compared with 302 grams, the average weight of adults. Their stomachs were distended with finely eut food, and were found to weigh on an average 5.4 grams, or about one-fifteenth their total weight as against the one-to-twenty ratio in adults. It would seem that partly grown young eat more in proportion to their size than old squirrels-which was rather to be expected.

There seem to be two periods of maximum daily activity aboveground on clear days, about 9 a.m. and again in mid-afternoon. This squirrel seems to be preëminently a sunshine forager. One day when a thunderstorm came up in the afternoon the squirrels nearly all disappeared from aboveground coincidently with the gathering of the clouds.

The breeding season of the Oregon Ground Squirrel, as is to be expected, varies with altitude, or, rather, with life-zone. The young are born later in the Transition and Boreal zones, than in the Upper Sonoran. On May 15 scores of adults were seen on Bull Meadows, near Goose Nest Mountain, 5,000 feet altitude, in the Canadian zone, but not one youngster was seen; while on May 16 everywhere in Butte Valley around Macdoel, at 3,000 feet, in the Upper Sonoran zone, young were out in great numbers. All of these were of about the same size, onefourth to one-third grown, showing the uniformity of time of birth throughout a region of uniform temperature conditions. On May 19, 1910, a collecting party from the California Museum of Vertebrate Zoology found small young, just out, on Sugar Hill, 5,000 feet altitude, Modoc County.

There is but one litter a year, and the number to a litter is supposed to vary from 4 to 15 , averaging about 8 . Exact statistics from which to determine these figures accurately are not available. A man who was irrigating an alfalfa field near Macdoel regularly day after day told us that he had drowned out many families of young and that the broods he had seen consisted of from 4 to 11, averaging, he thought, 8. Mr. W. C. Jacobsen, from his own extensive experience with this species, considers 4 and 12 to be extremes, and 8 the average. He knows, indirectly, of one case of 15 .

The Oregon Ground Squirrels lie dormant in a dry nest beneath the surface of the ground for fully half the year, even at the lowest altitudes in the general territory inhabited by them. The bulk of the population goes into hibernation during July and does not come out until March. These statements are made upon the authority of Mr. W. C. Jacobsen, who is further of the opinion that the exact time of disappearance, which varies somewhat from year to year, is controlled by moisture and consequent supply of green food. The drier the year the earlier the squirrels go into winter quarters, this in spite of the hotter late-summer temperature at the lower altitudes. In 1915, the squirrels in Big Valley, Lassen County, had nearly all gone in by July 3; in Warm Springs Valley, Modoc County, they had gone in by July 10; but on the Warner Mountains, Modoc County, they were just going in on July 22 of the same year. In 1914, a year of more moisture and better feed, the time of 



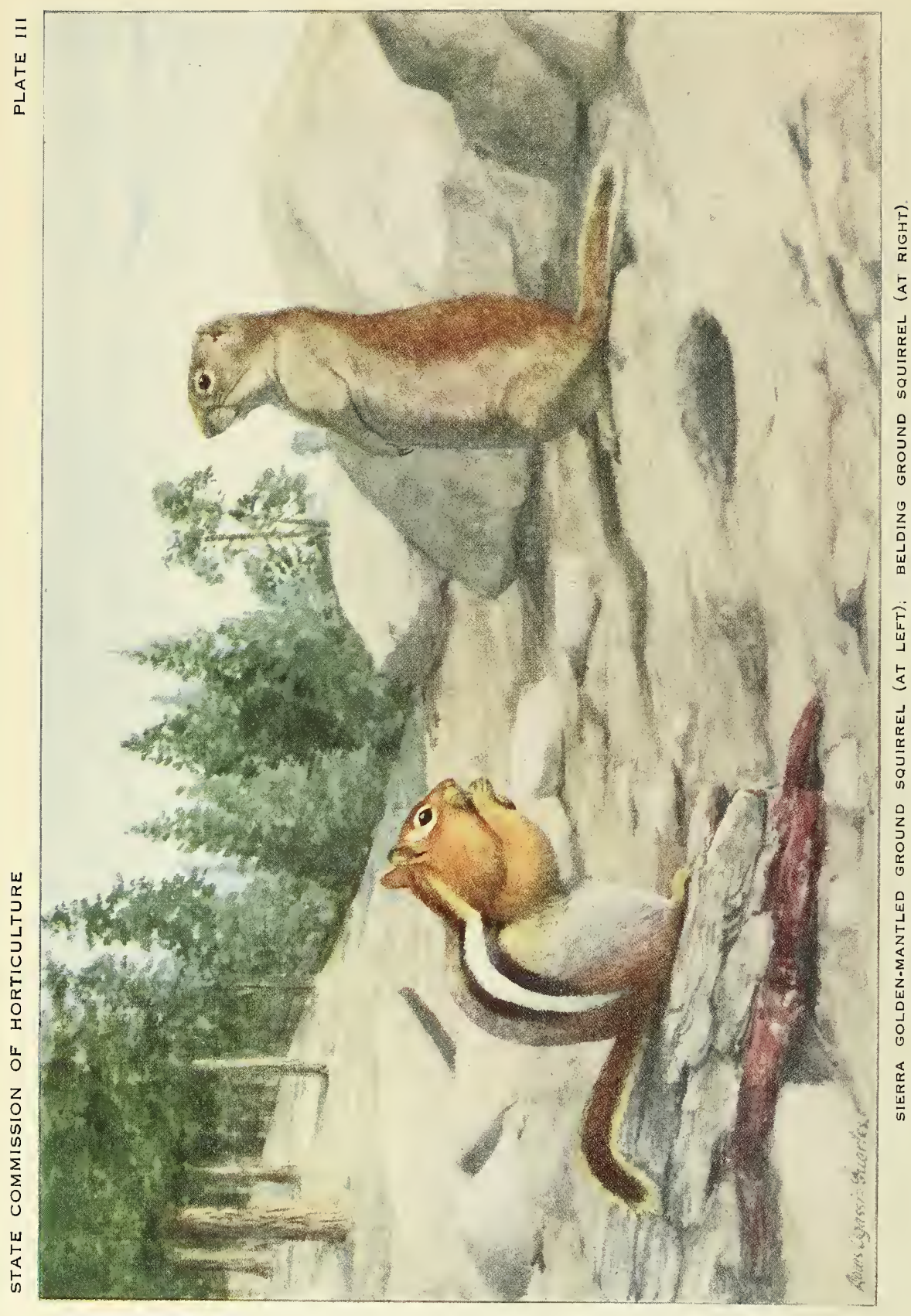


beginning hibernation at the same points was one and one-half to two weeks later. Individuals have been reported to us as seen aboveground as late as the first week of September, but all reports agree that the majority are "holed up" before the first week in August.

In the spring the animals reappear often when there is yet much snow on the ground. In 1916 they were out in force on March 16, when they had burrowed up in places through two feet of snow and were nibbling the sagebrush tips (W. C. Jacobsen, MIS).

Enemies of the Oregon Ground Squirrel were, under original conditions, doubtless numerous and effective in keeping down its numbers. Gopher snakes, rattlesnakes, badgers, coyotes and Swainson Hawks are known to feed regularly on it. Mr. J. O. Miller, a professional trapper living at Yreka, informs us that nine out of ten coyotes trapped by him during the summer months have remains of ground squirrels in their stomachs. One coyote taken in Butte Valley had parts of seven Oregon Ground Squirrels in its stomach. An old-time resident near Alturas told the senior author that the killing off of the "varmints" (predaceous animals) in recent years seemed to him to have had something to do with the increase and spread of ground squirrels. We are strongly inclined to his belief. Encouragement of those natural enemies which are not in themselves seriously detrimental to man's interests would go far to check the undue increase of the ground squirrels.

\section{BELDING GROUND SQUIRREL.}

\section{Citellus beldingi (Merriam).}

\section{PLATE 111 .}

Other names.--Belding Spermophile; Bob-tailed Spermophile; Prairie Dog, part; Picket-pin, part; Spermophilus elegans; Spermophilus beldingi; Colobotis beldingi.

Field characters.-A medium-sized, short-tailed, "picket-pin" type of ground squirrel, without side-stripes or other conspicuous markings, but with bright reddish brown back. Length of body alone about $7 \frac{4}{5}$ inches, with tail $2 \frac{2}{3}$ inches more. (Closely similar to Oregon Ground Squirrel, but smaller and with back reddish hrown instead of brownish gray; compare figs. 20a and 20b.)

Description.-Adult in full fall pelage: Sides of head, hind neck, shoulders, sides of body and flanks continuously yellowish brown (numerous fine hairs which are chiefly black, though light-tipped, lend a dusky tone to these areas); a tinge of oliveochre pervades the lower margins of those areas adjoining the light underparts; eyelids white; whiskers black; ears dusky, finely haired, not tufted; crown of head to nose. tawny-olive; a broad sharply outlined band of bright hazel brown running down middle of back from between shoulders, narrowing to base of tail. Tail short, fullhaired, flattish; above mixed hazel and black, black predominating toward end, where also a well-defined buffy white fringe: under surface of tail conspicuously deep cinnamon-rufous, with subterminal black interval, and buffy white fringe all around. Upper sides of feet buffy white; claws chiefly black, with horn-colored tips; palms naked; soles naked save for sparse hairing from heel halfway to tubercles. Under side of head and neck, and inner sides of fore and hind legs, buffy white; belly cream-color, with lead-color of bases of hairs showing through.

Color-variations.-As far as we can see from the series of specimens studied, adults molt but once a year, during July. May and June specimens show clearly the effects of wear and fading, and are grayer, with the mid-dorsal brown area much duller than in the fresh pelage described above. Young not one-fourth grown are like adults in color, but with mid-dorsal area paler, snuff brown, and under side of tail clay color. 
Measurements. - Average and extreme measurements, in millimeters, of twenty mature specimens from the Yosemite section of the higb Sierra Nevada are as follows: Ten males: total length, 263 (230-280); tail vertebræ, 66 (60-74); hind foot, $44(41-45.5)$; ear from crown, 9 (7-11); greatest length of skull, 44.5 (42.2-46.3) ; zygomatic breadth, 28.0 (26.4-29.5) ; interorbital width, 10.5 (9.7-11.0) Ten females: total length, 260 (240-2SS); tail vertebræ, 66 (55-74); hind foot, 43 (40-46) ; ear from crown, 10 (S-13) ; greatest length of skull, 44.0 (41.3-46.5) ; zygomatic breadth, 28.2 (26.7-28.9) ; interorbital width, 10.4 (9.7-11.0).

Relatively old individuals show greatest size, especially of skull, which also has acquired more conspicuous ridges and sharper angles. Males average a trifle larger than females.

Weights.-Average and extreme weights, in grams, of twenty mature specimens from the Yosemite section of the high Sierra Nevada are as follows: Ten males, 222 (125.5-285.0) ; ten females, 240 (172-305). Average, in ounces, both sexes, about 8.

The example showing the least weight was fully adult, but was very lean. Like other ground squirrels this species varies greatly in weight according to the amount of fat present. Specimens taken in August and September are, as a rule, fattest.

Type locality.-Donner, Placer County, California (Merriam, 1888, pp. 317-320).

Distribution area.-Higher parts of the central Sierra Nevada (chiefly Hudsonian life-zone), from vicinity of Independence Lake, Nevada County, south to southeastern border of Yosemite National Park in vicinity of Mount Lyell (see fig. 18). Altitudinal range, from 11,800 feet (as on Mt. Conness) down on western flank of Sierras to as low as $\$, 100$ feet (Porcupine Flat, Yosemite Park) ; on easte n flank to as low as 6,500 feet, at western border of Mono Lake (Mus. Vert. Zool.).

Specimens examined.-A total of 48 from the following localities in California: Nevada County: Independence Lake, 13. Placel County: "Johnson's Pass, High Sierras" [= Summit], 1. El Dorado County : Mt. Tallac, 1. Alpine County : Hope Valley, 4. Mono County: Mono Lake P. O., 1; Farrington's, Mono Lake, 3 ; Mono Pass, 1; Tioga Pass, 1; Walker Lake, 1. Tuolumne County: Tuolumne Meadows, 8; middle Ljell Canyon, 1; head Lyell Canycn, 5. Mariposa County : Mt. Hoffman, 10,700 ft., 1; Tioga Road, southeast Mt. Hoffman, 3; near Vogelsang Lake, 2 ; two miles east Porcupine Flat, 1; one mile east Lake Merced, 1.

This species of ground squirrel was named after Lyman Belding, an early resident of Stockton and a naturalist of considerable attainment. Belding found it in the summer of 1885 in the vicinity of Summit, Placer County, and sent a specimen to Dr. C. Hart Merriam, who later (1888) described the species, calling it Spermophilus beldingi.

The most notable thing about the Belding Ground Squirrel is the great altitude of most of the area it inhabits. It is very closely restricted to the alpine meadows of the high central Sierra Nevada. The warmer levels below seem to be just as inimical to its welfare as the cold upper zones certainly are to the other ground squirrels which inhabit the middle slopes or foothills. Reference to our diagram (fig. 23) will show some interesting facts in this regard. We would infer that the Belding Ground Squirrel is the hardiest of all our species as regards ability to endure long and cold winters, though here the habit of hibernation must come importantly into play as tiding it over the extremes.

This squirrel occurs in fair abundance on the preferred portions of its general range, namely, the grassy meadows in the neighborhood of timber line. Individuals rarely occur down as low as the belt of red firs and aspens (Canadian zone) on the west slope of the Sierras, though on the east slope a few do occur down through the Jeffrey pine belt. It is quite strictly an inhabitant of open levels; it is rarely or never seen in the woods or on steep or rocky slopes. Occasionally an individual ascends to the top of some glacier-borne boulder out in a meadow for a look around, but we have yet to observe any greater exploit in climbing. 


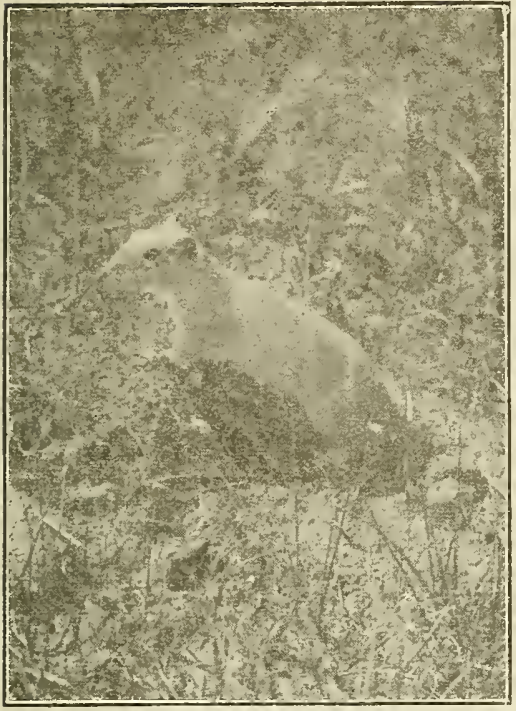

(a) Oregon Ground Squirrel in meadow near Klamath Falls, Oregon. Photographed by H. C. Bryant, May 30 , 1914. Note uniform coloration with no indication of a reddish brown patch on back.

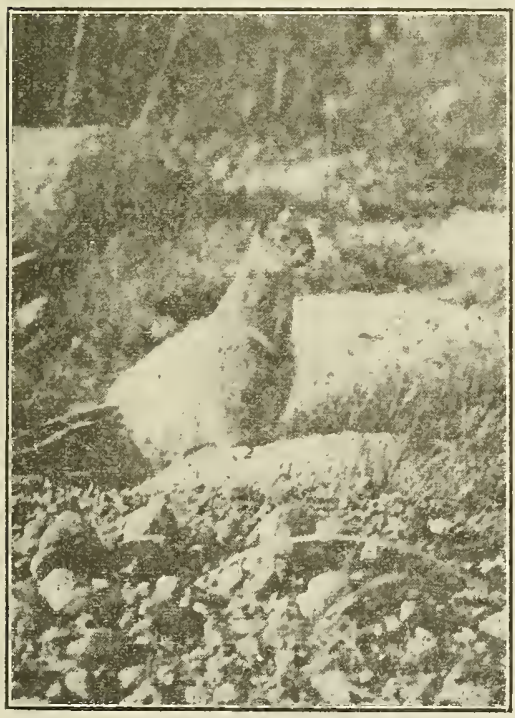

(c) Same squirrel as shown in $b$ standing upright in characteristic "picket-pin" attitude.

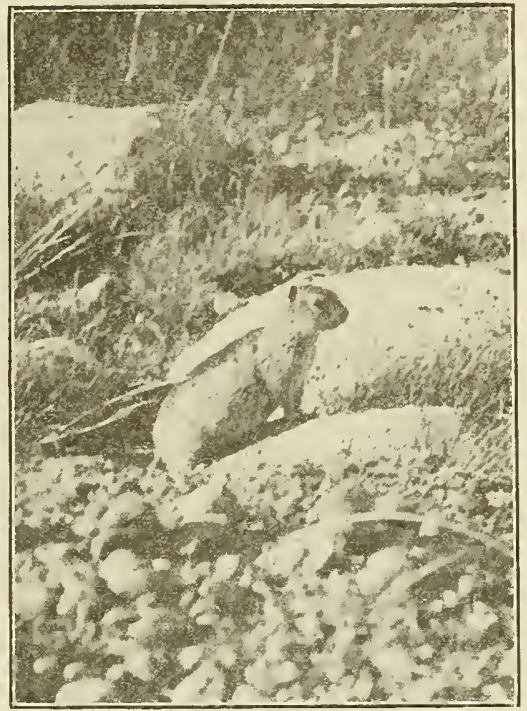

(b) Female Belding Ground Squirrel at entrance to burrow; Tuolumne Meadows, Yosemite Natlonal Park. Photographed by T. I. Storer, July 27. 1915. Note patch on back rendered photographically nearly black, but which was reddish brown. Compare with $a$.

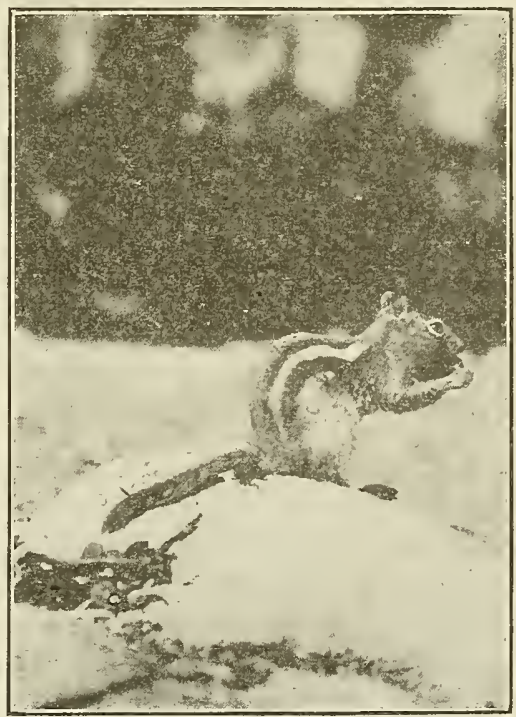

(d) Sierra Golden-mantled Ground Squirrel or "bummer," feeding on scraps from the camp table. Note the distended cheek. Bullfrog Lake, 10,600 feet. Fresno County. Photographed by J. Dixon, September 1, 1916. 
Probably because of the open nature of their forage ground, these squirrels seem exceptionally timid. The shrill cries of alarm greeting the invader of a meadow upon his approach are quickly followed by total disappearance of the animals, at least for the time being. Each individual seems not to wander usually more than a few yards from the mouth of its burrow, so that but a short run intervenes at any moment between it and safety. The tail is held down when running, not elevated nor waved. The gait is rather slow and clumsy, impressing one observer as resembling that of a short-legged dog. "Where the grass is short there is little up-and-down movement of the body shown in running; but in high grass, instead of parting the stalks and pressing them aside as it progresses, the animal advances by a series of jumps each of which carries it up clear of the grass so that it can glimpse about for a possible enemy" (T. I. Storer, MS).

When within but a few feet of the mouth of its burrow and first taking alarm, a squirrel will rise quickly on its haunches and assume the rigid, upright, "picket-pin" posture (see fig. 20e). This usually brings the animal's head well above the grass tops, so that it can get a good view all about. Also it can then be seen a long way, looking in the distance like a tent-stake or picket-pin out on the meadow. During this pose the fore limbs are pressed closely against the body. Sometimes the animal rises still higher, supporting its whole body on its hind feet and using its stubby tail as a prop (C. L. Camp, MS). The fact that the nose is continually twitched up and down, as if the animal were drawing in air, suggests that the sense of smell may be keen and that it may be used to determine the nature of a supposed enemy. If the observer continues his approach the squirrel suddenly deserts its "picket-pin" pose and dashes for its burrow, where it may hesitate a moment on all fours for one final look before diving out of sight.

The voice of this squirrel closely resembles that of the Oregon Ground Squirrel. The usual call of warning consists of a series of from five to eight short shrill whistles uttered in quick succession and weakening toward the last. Females warn their young when foraging abroad with a lower-pitched, double note, or bark, e-chert'. A single note, sirt, is also frequently heard.

The burrows of the Belding Ground Squirrel are generally located in the meadows which form their forage grounds. Sometimes, near timber line, one finds them in the scant gravelly soil between granite boulders, but always in or near patches of the kind of bunch grass occurring at such altitudes. The mounds are rarely conspicuous, and the holes open up to the surface steeply. Often there is no surplus earth at all around the mouths of the burrows, but this condition might be accounted for by the effects of washing from heavy rain or melting snow. Several measurements of burrows gave an average diameter of two inches. The extent of the underground burrow system has only been tested out in one instance (see fig. 21). In this case the burrow was located in a wet meadow, snowbanks melting all about at the time (June 28), and it proved to be shallow, reaching an extreme depth of only about thirteen inches. But blind branches directed downward indicated the probability of greater depth later in the season when the water table had lowered and the soil dried out. The total length of this burrow system, including all its branches, was close to 54 feet. 


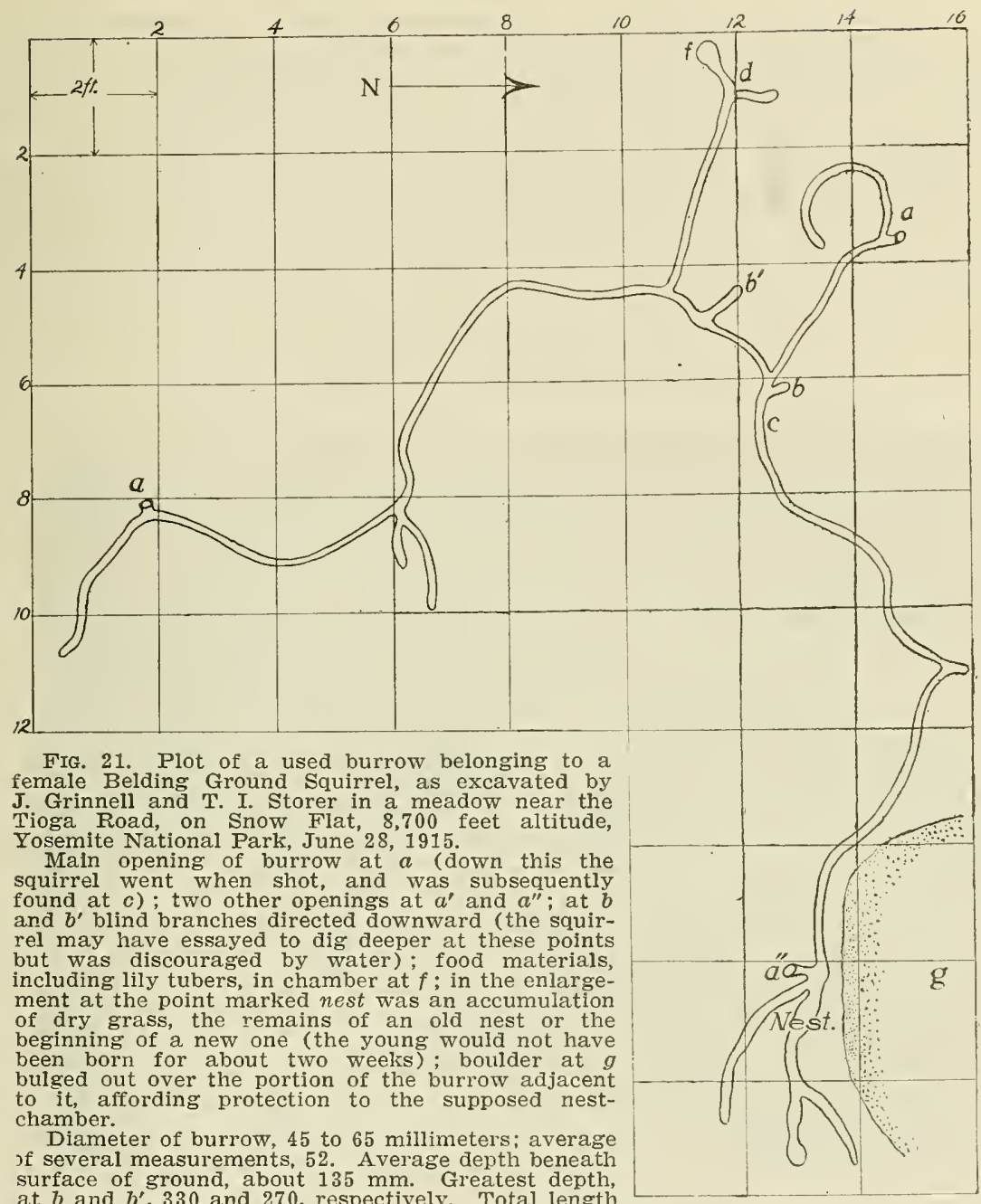
surface of ground, about $135 \mathrm{~mm}$. Greatest depth, at $b$ and $b^{\prime}, 330$ and 270 , respectively. Total length of system, about 54 feet.

The burrow system above described belonged to just one squirrel, an adult female, which was found to contain five embryos, the only exact evidence we have as to the number of young to a litter. This was at 8,700 feet altitude, on Snow Flat, Yosemite Park, on June 28. Halfgrown young were common on Tuolumne Meadows, 8,600 feet, July 16. Young two-thirds grown have been taken at Independence Lake, Nevada County, 7,000 feet altitude, as early as July 13. Three third-grown young were seen, and one of them photographed (fig. 22), at 6,800 feet altitude near Williams Butte, Mono County, June 28. There is thus probably some variation in time of appearance of the young, with altitude, the animals at the highest levels being born latest in the season. The young are out quite generally by the 15 th of July. Only one litter 
is born each year. On July 31, on Tuolumne Meadows, Yosemite Park, young Picket-pins were out in parties of six mostly, and sat about the mouths of their burrows or foraged in the very near vicinity. When frightened all members of each group darted for their refuge at the same time, crowding into the hole with some difficulty.

Belding Ground Squirrels become very fat in late summer and hibernate regularly; but exact dates of beginning hibernation in the autumn and emerging in the spring are wanting. We do know that they are not averse to running about over the surface of the snow at high altitudes in June, and so probably come out much earlier, and that in one year, 1915, they were still out as late as October 7 in the vicinity of Ten Lakes, Yosemite Park, although a light snowfall had already occurred. They were numerous on the extensive meadows in Tioga

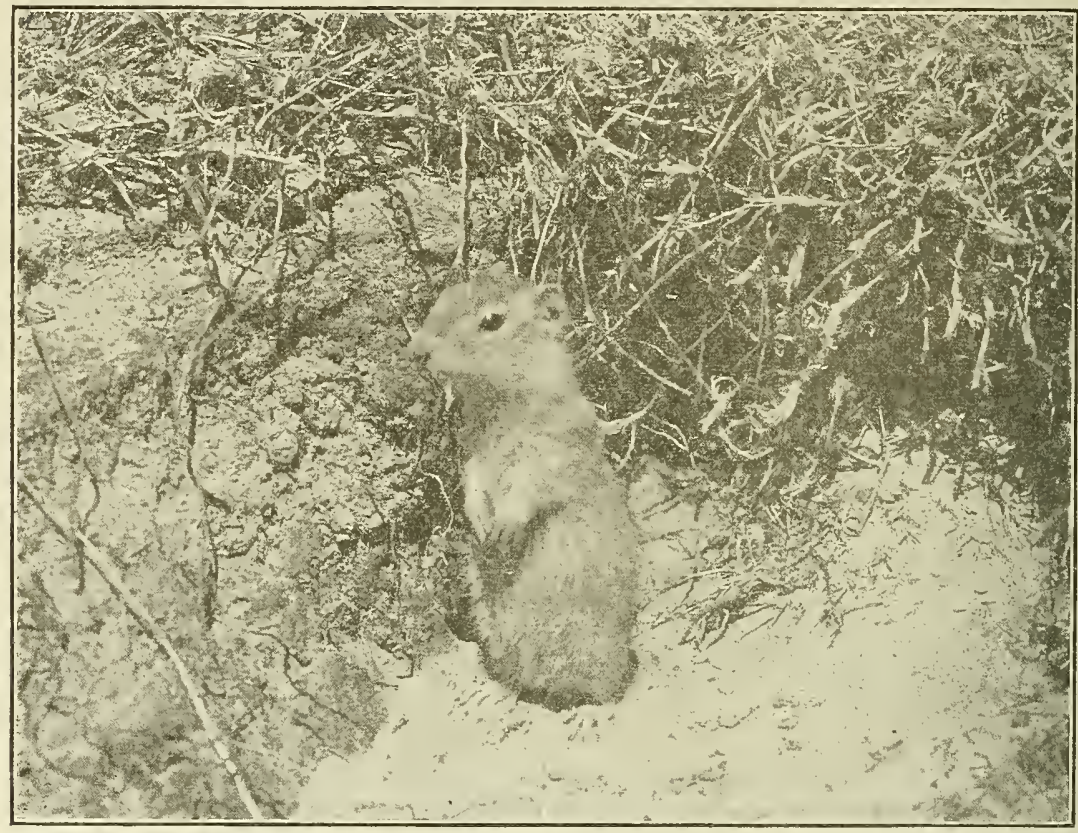

FIG. 22. Third-grown young Belding Ground Squirrel; photographed by J. Dixon, June 28, 1916, near Williams Butte, Mono County.

Pass on September 28. It is evident that, in spite of its more elevated habitat, the Belding Ground Squirrel goes into its winter sleep a full two months later than the Oregon Ground Squirrel.

Like the Oregon Ground Squirrel, the Belding feeds largely on grass stems and blades. An individual has been seen gathering seeds from grass heads, pulling the latter down to its mouth with its fore feet; but it is certainly not the seed-eater that the California and Goldenmantled ground squirrels are. Neither is there evidence that the Belding stores up much food. As with the Oregon species, its cheek-pouches are small (see fig. 13b). At Soda Springs, on Tuolumne Meadows, the Belding Squirrels have been seen foraging like rats about the mule corral. 
The enemies of this species of squirrel probably include most of the carnivores of the high mountains. A Mountain Weasel (Mustela artzonensis) has been seen to kill one by biting it through the back of the neck (C. L. Camp, MS).

The Belding Ground Squirrel bears no decided economic importance, save as might be involved in the grass it eats. Its habitat falls only within the summer range of sheep and cattle, and its numbers are nowhere so great as to be likely to reduce the crop of pasture grass to any material extent.

\section{STEPHENS SOFT-HAIRED GROUND SQUIRREL.}

Citellus mollis stephensi (Merriam).

Other names.-Stephens Spermophile; Picket-pin, part; Stephens Ground Squirrel; Spermophilus nollis stephensi.

Field characters.--Small size combined with very short and slender tail and gray coloration (no stripes or special markings) ; ear small; length of body alone about 61 inches, with tail about 2 inches more.

Description.-Nearly full-grown young in summer pelage (June) : General tone of coloration on upper surface of body, buffy gray; top of head from nose to bind neck, pale cinnamon-buff, deepest ou nose, and changing into color of back on shoulder; cheek to shoulder, olive-buff; eyelids white; whiskers black; back light drab with a faint effect of fine dappling; the hairs on the back lead-colored at extreme bases, then gray, then bister, and tipped with buffy white. Upper surfaces of feet dull white; palms naked; soles of hind feet clothed with dull whitish hairs to about halfway forward from heel; claws blackish, with horn-colored tips. Tail flat-haired, but narrowly so, and tapering from base to tip; upper surface buffy drab; beneath dull white at base, becoming dusky pinkish buff toward end. Lower surface of body silrery white, faintly buff tinged, particulariy as forming a band along each side, and with much of the leaden-bued bases of the hairs showing through.

We have at hand but two specimens of this ground squirrel, and these are both immature.

Color variations.-A considerable series of specimens of Citellus mollis (subspecies?) at hand from northern Nevada make it seem likely that stephensi varies in color but little from the coloration as here described; probably old adults are grayer, with little or none of the cinnamon-buff about the head. The summer pelage at all ages is notably soft and silky as compared with that of most other species of ground squirrels at the same season. There is possibly a distinct winter pelage, with regular molts in spring and fall; but we have no specimens to indicate this.

One of our two specimens has the tail much flatter, and broader ended, than the other; but this we think is due to the way the tail was wired when the skin was prepared. The usual thing is for the tail to taper from base to tip, thus quite unlike the condition found in the Mohave Ground Squirrel.

Measurements.-Nine specimens from the head of Owens Valley, in California, average, in millimeters as follows: total length, 212; tail vertebræ, 50; hind foot, 32.4 (Merriam, 1898, p. 70).

The two immature specimens in the Museum of Vertebrate Zoology, from near Mono Lake, measure as follows, the first figures given being for the male, the second for the female: total length, 195,185 ; tail vertebræ, 45,45 ; hind foot, 32 , 32 ; ear from crown, 4,4 ; greatest length of skull, . ., 35.6; zygomatic breadth, 21.8, 22.0; interorbital width, $7.4, \ldots$.

Weights.-Our two specimens weigh, in grams, as follows : male, 83.6 ; female, 78.0 (in ounces, about 3 and $2 \frac{3}{4}$, respectively).

Type locality.-Queen Station, near head of Owens Valley, Nevada [in Esmeralda County, just across California boundary] (Merriam, 1898, p. 69). 
Distribution.-Within the state of California, in only a very limited area comprising the sagebrush valleys of eastern Mono County, namely from southeastern edge of Mono Lake to head of Owens Valley in vicinity of Benton Station (see fig. 18). Life-zone, Upper Sonoran chiefly, barely entering Transition locally (see fig. 23). Southernmost known locality of occurrence, Taylor Ranch, in Owens Valley, two miles south of Benton Station. Altitudinal range, 5,300 to 7,300 feet.

Specimens examined.-A total of 2, both from Mono County : Mono Mills, 1; Dry Creek, 1 .

The Soft-haired Ground Squirrels belong to the Great Basin region of the western United States and get into our California list only on the basis of the occurrence of one of the subspecies, the Stephens, in a few places along the eastern border of the state. This is a distinctly different type of ground squirrel from any of our others, notably in the soft, silky "feel" of the hair. In addition, the small size, short slender tail, and uniform light grayish coloration make a combination of characters which is unique among our species.

Unfortunately, our own personal experience with this species has been very limited. In September of 1917 the two of us made especial search for it at the extreme head of Owens Valley. But we were too late in the season; locally well known in the vicinity of Benton, we were assured by the ranchers that the animals had all "holed up" by about the end of July. On the Pellisier Ranch, five miles north of Benton Station, "Picket-pins" were declared to have been present "by the million" from April until July, but it was averred that by the last of August they had all disappeared. Numerous round holes in the ground among the sage bushes were pointed out to us as belonging to these squirrels. There was abundant evidence that coyotes and badgers regularly dig them out. Also we were told that at the season the squirrels are above ground the Indians capture many for food.

On the Taylor ranch this squirrel was reported to be plentiful, but to vary much in numbers from year to year. In the spring of 1916 it was abundant; in 1917 scarcely any were seen.

In the sand-dune area along the east side of Mono Lake, the junior author saw several Soft-haired Ground Squirrels on June 10, 1916. The sand was fairly covered with their tracks. Those individuals seen on June 11 near Dry Creek in the same neighborhood were notably tame. They gave the impression of being flat-bodied, and slid along the ground like lizards, stopping to scrutinize the intruder from the shelter of the first bush reached. One was captured under a bush by being pinned down with the gun.

Mr. Frank Stephens of Sau Diego, for whom this subspecies was named, states $(1906$, p. 71) that he found the animals "pather common in the valleys of eastern Mono County." They were feeding on the sagebrush and were exceedingly fat. The date of capture of the type was July 12, 1891 (Merriam, 1898, p. 69). 



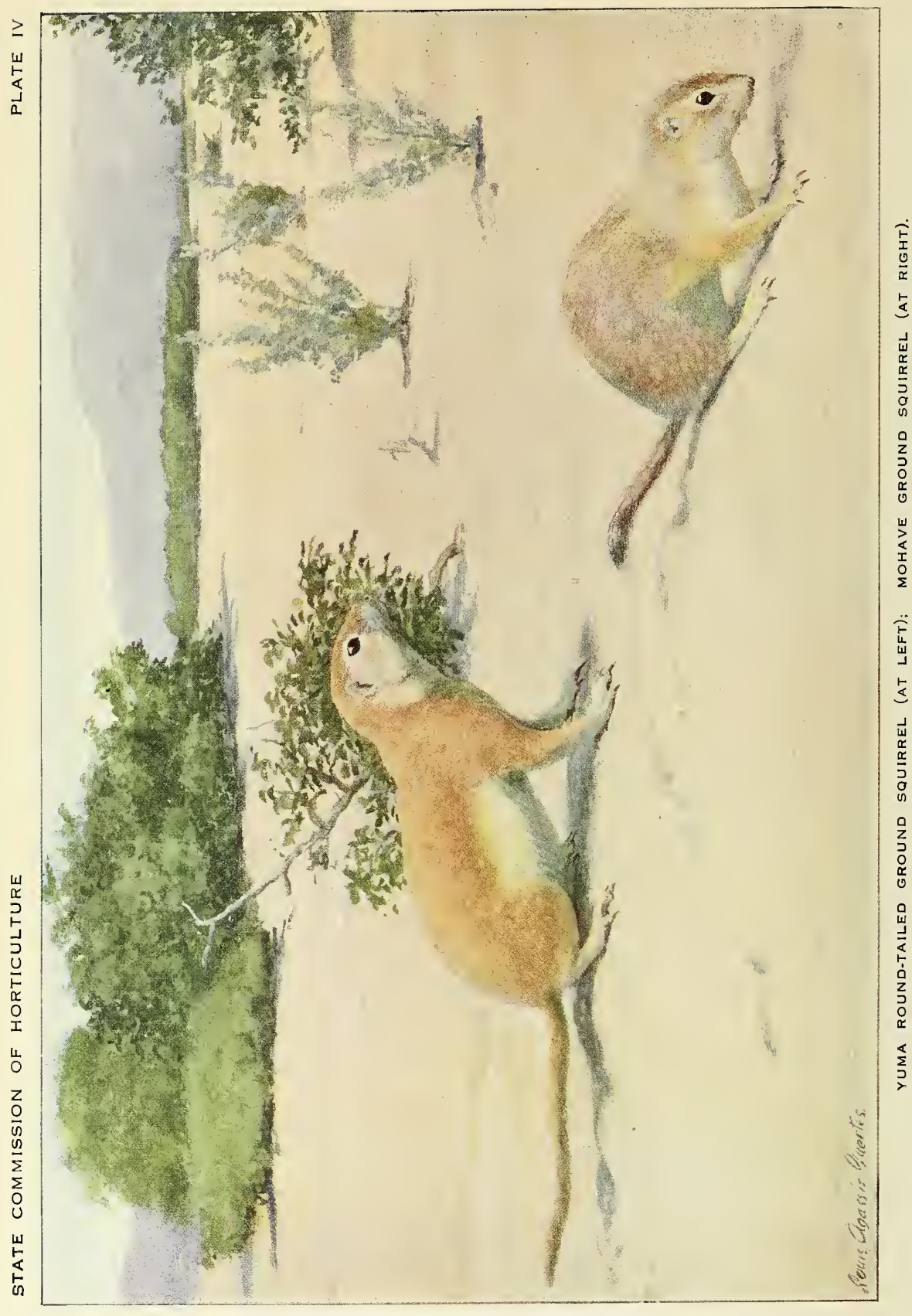




\section{MOHAVE GROUND SQUIRREL.}

\section{Citellus mohavensis (Merriam).}

PLATE IV.

Other names.-Mohave Desert Spermophile ; Mohave Desert Ground Squirrel, part; Spermophitus mohavensis; Citellus tereticaudus mohavensis, part.

Field characters.-A small-sized, brown-colored ground squirrel, without stripes or special markings whatsoever on the body, but with short broadly haired tail, white underneath; ear a mere rim; length of body alone, about $6 \frac{1}{2}$ inches, with tail about $2 \frac{1}{2}$ inches more.

Description.-Adult in full winter pelage: General tone of whole upper surface from nose to base of tail cinnamon drab; hairs on back when examined closely are seen to be lead-color at base, then ashy white, then army brown, and tipped with white; mixed with these hairs are a few of solid black color, and on the rump some which are black with a white interval near end. Eyelids white, but cheeks like back; rim of ear and upper sides of feet tinged with light pinkish cinnamon; palms of fore feet naked; soles of hind feet clothed with long buffy hairs; claws black with lorn-colored tips. Under surface of body silvery white, but slaty bases of hairs show through making the general effect light gray. Under surface of the flattish stubby tail pure white; upper side like back at base, becoming mixed black and white toward end; extreme end with white fringe. Adult in summer pelage: Coat very much coarser and shorter than in winter; general color tone browner, close to cinnamon, but a grizzling effect is produced by white hair-tippings everywhere on upper surface. Sides of face paler than in winter, and lower surface of body pure white, owing to lack of lead-color at bases of individual hairs.

Color variations.-Specimens of dates May 3 and 12 are in process of molt from winter to summer pelage. Patches of worn and yellowed winter hairs remain on the fore back and rump. The tail is seemingly not included in the spring molt, and the old tail hairs become crinkled and broken at the ends; the white of the under side is dingy, and a dark subterminal band around the end of the tail shows through.

Measurements.-Average and extreme measurements, in millimeters, of seven adult specimens (5 males, 2 females), from the northern part of the Mohare Desert are as follows: Total length, 224 (212-230) ; tail vertebræ, 62 (42-72) ; hind foot, 36 (34-37) ; greatest length of skull, 38.6 (3S.1-39.0); zygomatic breadth, 24.3 (23.6-25.3); interorbital width, S.7 (S.2-9.2).

The two sexes appear to be alike in measurements as well as in coloration.

Weights.-An adult male, not particularly fat, was found to weigh 104 grams (about $3 \frac{2}{3}$ ounces).

Type locality.-Mohave River, California (Merriam, 1889, p. 15). More exactly, near Rabbit Springs, about 15 miles east of Mohave River at Hesperia, in San Bernardino County (Stephens, in conversation, January 1, 1916).

Distribution area.-Not continuous; western parts of the Mohave Desert, from Haiwee, Inyo County, south to Rabbit Springs, San Bernardino County (see fig. 18). Life-zone, Lower Sonoran, though only in its upper portion apparently. Altitudinal range, 2,500 to near'y 4,000 feet.

Specimens examined.-A total of 8 , from the following localities in Califoruia: Inyo County: Haiwee Meadows, 3,750 feet alt., about teu miles south of Owens Lake, 2 (in coll. U. S. Biol. Surv.) ; Little Lake, 3,100 feet, 2 (Mus. Vert. Zool.). San Belnardino County : Salt Wells Valley (eastern edge near Inyo County line), 2,500 feet, 3 (U. S. Biol. Surv.) ; Rabbit Springs, 2,900 feet, east of Mohave River, 1 (in coll. F. Stephens).

The Mohave Ground Squirrel, although first discovered in 1886 by Mr. Frank Stephens of San Diego, has remained about the least known of all our rodents. Only four rather seattered localities of occurrence are definitely known, as listed above under "Specimens examined." The dates represented are March 22 and 24, May 3 and 12 and June 5. 
The two specimens in the Museum of Vertebrate Zoology were trapped on the first two specified dates, in 1918, on the hillsides immediately west of Little Lake. They were daytime-taken in oat-baited rat-traps set beneath creasote bushes on gravelly ground. In spite of diligent search by the collectors everywhere in the neighborhood, not one of this species was seen alive. No information is available to us in regard to either behavior or food.

This ground squirrel is altogether distinct from Citellus tereticaudus. There is no indication of intergradation with that species, as stated by Elliot (1904, p. 291). In fact, the animals reported by that author from Daggett were all probably in reality tereticaudus, which species is known to us to be present at Daggett. The tail of mohavensis is always much shorter and more broadly haired than in tereticaudus, the claws are stouter, the cheeks are brownish instead of white, the under side of the tail is white, instead of buffy with brown mottlings toward the end, the quantity of winter pelage is greater, and the general tone of coloration is always decidedly dark.

The fact that the under side of the tail is white, as in the Antelope Ground Squirrel, leads us to suspect some such special habit of displaying this member as is possessed by the latter animal. But this is mere speculation. The relationships of mohavensis as indicated by structural features are thought to lic rather with Citellus than with Ammospermophilus.

\section{YUMA ROUND-TAILED GROUND SQUIRREL.}

Citellus tereticaudus tereticaudus (Baird).

PLATE IV.

Other names.-Round-tailed Spermophile; Tuma Ground Squirrel; Mohave Desert Ground Squirrel, part; Spermophilus tereticaudus; Xerospermophilus tereticaudus; Citellus tereticaudus mohavensis, part.

Field characters.-A small ground squirrel, of slencler build, and of pale brown color (no stripes or other markings) ; tail long and slender, not broadly baired; ears very small, mere rims; length of body without tail about 6 inches, with tail about $3 \frac{3}{4}$ inches more.

Description.-Adult in winter pelage: Whole upper surface from nose to and including tail, light pinkish cinnamon in general tone; individual hairs lead-colored at extreme bases, then dull white, then pinkisl cinnamon, and with tipping of white. Eyelids and whole lower surface to root of tail, white; side of head and neck including ear dull white; whiskers black; hairs of belly lead-colored at extreme bases. Upper surfaces of feet dull buffy white; claws dark brown basally, becoming horncolor at tips; soles of feet haired save for under sides of toes. Tail cylindrical in shape, a little more heavily haired toward end than at base; under side dull buff, with black mottlings in fine pattern toward end; above like back on basal half, becoming black and buff mottled toward end; hairs at tip of tail brown at their bases, then buff, then broadly black, and with white ends.

Adult in summer pelage: Coat short and harsh as compared with winter coat; color above brighter pinkish cinnamon. Otherwise as in winter, but the tail, which apparently does not molt, pale brown and still slenderer, due to the fading out of the dark colors and to the wear and consequent shortening of the hairs.

Color variations.- - Young partly grown are colored like summer adults, but the pelage is not quite so harsh and on the under surface is so sparse as to allow the bare skin to show through in places. There are two molts in the adults each year 
and two distinct pelages separated by these. The spring molt occurs during April (March 28 to May 1 according to specimens at hand), and the fall molt probably during October though there are no specimens available to show its extent. The remnants of the winter pelage during the spring molt become faded in some specimens to a dull yellowish tone. This molt advances in a general way from the front backward, but specimens often show a patchy or mixed coat on the back and rump.

Measurements. - Average and extreme measurements, in millimeters, of seventeen adult specimeus from the Colorado and Imperial valleys are as follows: seven males: total length, 247 (225-261) ; tail vertebræ, 95 (S5-107); hind foot, 36 (31-37); greatest length of skull, 37.1 (35.2-3S.2); zygomatic breadth, 23.5 (22. -24.4$)$; interorbital width, $S .9(S .3-9.5)$. Ten females: total leugth, 241 (216-258); tail vertebræ, 91 (75-102); hind foot, 36 (33-38); greatest length of skull, 36.0 (34.3-3S.2) ; zygomatic breadth, 22.2 (21.3-23.4); interorbital width, 8.6 (8.0-9.5).

Males are seen to be slightly larger than females. The ears in this species are small, the rims rising not more than 3 millimeters ( $\frac{1}{8}$ inch) above their inner base. In but few specimens did the collector attempt to secure the measurement of the ear.

Weights.-Stephens (MS) found two females and a male to weigh together 12 ounces, an average of 4 ounces each. "All were thin."

Type locality.-Fort Yuma [Imperial County], California (Baird, 1857, pp. 315-316).

Distribution area.-Low-lying sandy areas on the Colorado and Mohave deserts. Life-zone, Lower Sonoran (see fig. 23). More specifically: the Imperial Valley west as far as La Puerta (Mus. Vert. Zool.) in extreme eastern San Diego County, north to the southern end of Salton Sea, and east to old Fort Iuma; thence north along the Colorado River nearly or quite to the Nevada line; and from the vicinity of Needles and Blythe, in the Colorado Valley, northwestward across the central part of the Mohare Desert to at least as far as Kramer (Grinnell, MS), in west-central San Bernardino County. Altitudes of occurrence, from 200 feet below sea-level to 2,300 feet above. The range of this species is not continuous over the area just indicated ( from one another.

Specimens examined.-A total of 28 from the following localities in California : San Bernardino County, one-half mile north of Barstow, 1; Daggett, 1; Blythe Junction, 4; Needles, 3. Imperial County: south end of Salton Lake, 6; six miles south of Holtville, 2; Coyote WVell, 4 ; Pilot Knob, 4 ; Colorado River opposite Cibola, 2. San Diego County : La Puerta, 1.

The Yuma Round-tailed Ground Squirrel was first made known to science in 1857 from specimens taken by an army officer stationed at old Fort Yuma, which was situated on the California side of the Colorado River opposite the present town of Yuma. It inhabits the hottest of our southeastern desert valleys. Its metropolis lies in the Imperial Valley and thence north along the valley of the Colorado; a few colonies occur also on suitable parts of the Mohave Desert. Over this general region the species is by no means continuously distributed. It seems to be very particular in its requirements, only level ground of a sandy nature being as a rule inhabited at all. Places are preferred where wind-drifted sand has been accumulated into mounds about the bases of mesquite, creasote bushes, or salt bushes. Here the burrows are to be seen opening up among the stems of the partly buried shrubs; and the animals, if not actually seen themselves, are shown by their tracks in the sand surface to be in the habit of foraging out across the bare intervals for the seeds which are to be found sifted among the sand particles.

The squirrels themselves are usually shy and by reason of their obscure coloration and especially the shimmering glare on the desert surface are not readily observed unless particularly sought for. Neither are their total numbers very great even where conditions are fairly 
favorable. While our observations show them to be strictly diurnal in habits, we have noted an apparent aversion to direct sunshine. Perhaps this is because the sunshine on the desert is in summer so intense as to be quickly fatal to any small animal exposed to it for long. We know for a fact of squirrels caught in traps by one foot or merely a toe, on open ground, which have quickly succumbed- "sun-cooked" is the

\begin{tabular}{|c|c|c|c|c|c|c|}
\hline & \begin{tabular}{|l|} 
Eower \\
Sonoran \\
\end{tabular} & \begin{tabular}{|l|}
$\begin{array}{l}\text { Upper } \\
\text { Sonoran }\end{array}$ \\
\end{tabular} & Transition & Canadian & Hudsonion & Arclic \\
\hline Citellus beecheyi beecheyi & & & & & & \\
\hline Citellus beecheyi fisheri & & & & - & & \\
\hline citellus beecheyi nesioticus & & arsing & & & & \\
\hline Cilellus douglasii & & & & & & \\
\hline Citellus variegatus grammurus & $-\frac{1}{1}$ & 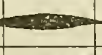 & & & & \\
\hline Citellus oregonus & & 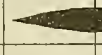 & 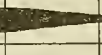 & & & \\
\hline Cilellus beldingi & & & & & 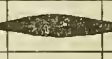 & 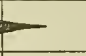 \\
\hline Cilellus mollis slephensi & & 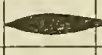 & 1 & & & \\
\hline Citellus mohavensis & $\infty$ & & & & & \\
\hline Citellus tereticaudus tereticaudus & $\rightarrow$ & & & & & \\
\hline Citellus tereticaudus eremonomus & $\rightarrow$ & & & & & \\
\hline Cilellus tereticaudus chlorus & $\longrightarrow$ & & & & & \\
\hline Callospermophilus chrysodeirus chrysodeirus & & & & & & - \\
\hline Callospermophilus chrysodeirus perpallidus & & & & & & - \\
\hline Callospermophilus chrysodeirus bernardinus & & & - & & and & \\
\hline Ammospermophilus leucurus leucurus & & & - & & & \\
\hline ammospermophilus nelsoni nelsoni & & & & & & \\
\hline ammospermophilus nelsoni amplus & $\infty$ & & & & & \\
\hline
\end{tabular}

FIG. 23. Diagram showing the ranges of the ground squirrels of California according to life-zones. (For life-zone map of California, see Grinnell, 1913, pl. 15.)

term we use for such victims. At any rate, the squirrels are seen crossing open spaces but momentarily, and thenceforth they remain in the shade of bushes until they take final alarm and descend into their burrows.

The long, slender, ratlike tail is exclusively characteristic of this species of ground squirrel. The body, too, is rather slender, though after a full meal of green stuff individuals have been seen which showed a rather pot-bellied outline. The mere rims of ears give the animal a round-headed look. The movements are rather more agile than in most of its relatives. It not infrequently climbs up into bushes to a height of four or five feet, but here it becomes clumsy.

The voice of the Round-tailed Ground Squirrel is unmistakable when once learned. As far as known to us, but one kind of note is uttered, a single high-pitched squeak or shrill whistle, seep, uttered only at rather long intervals, never in a series as with some others of the ground squirrels. The quality of this call is such that the direction from which 
it emanates is difficult to fix; also the distance is hard to determine. It seems to be given as a warning by an individual, either located within the moutl of its burrow (Stephens, 1906, p. 70) or when standing motionless under a bush. C. L. Camp (MS) records that he has seen an individual, when its curiosity was aroused, stand high up on its hind legs and utter its "sharp squeak" with the mouth wide open, at the same time "giving the thorax a violent contraction."

Facts in regard to the breeding of this squirrel are shown in the following data. On March 15 (1914) near Barstow a male Roundtailed Ground Squirrel was seen abroad which proved astonishingly indifferent. "It came up to where we were digging' out a kangaroo rat colony, smelling into various burrows, evidently intently hunting for a female. The testes of this animal were enormous, dragging on the ground behind it as it waddled along" (Grinnell, MS). "Two females captured in the valley of the Colorado River opposite Cibola, April 3 and 4 (1910), were found to contain six and four embryos, respectively; young about half grown were taken at Needles July 15 and 19 (1909) (Grimmell, 1914, p. 224). Stephens (1906, p. 70) says that the breeding season falls in March and April and that the number of young in a litter is four to seven. In spite of the long hot period each year in the habitat of this species, there is no evidence to show that more than one litter is reared annually.

There is a period of inactivity. during midwinter, when these animals are not seen abroad. Whether or not there is regular hibernation, as with the species of colder regions, we do not definitely know; but this seems to be the case.

"The food is seeds the greater part of the year; these are stored to some extent. In the spring, during the few weeks when green vegetation is obtainable, leaves and buds are eaten voraciously'" (Stephens, 1906, p. 70). In our experience, stems of the squaw-tea (Ephedra) and leaves of the mesquite form an important element of the diet wherever and whenever obtainable.

In June, 1918, W. C. Jacobsen (IIS) found several colonies of Yuma Round-tailed Ground Squirrels in the Imperial Valley within five or six miles south of Holtville. The interesting thing was that here the animals were invading the cultivated fields and were finding alfalfa suited to their tastes. Individuals were seen to eat the leaves of the alfalfa with avidity, but left the stems uneaten. Many dry stems were found lying about near the mouths of their burrows. At another point, near Bond Corners, oat hulls were seen around burrows.

There is a possibility, therefore, that this strictly desert rodent might come to liave an economic bearing on the reclaimed sections of the desert. Whether or not it will become a serious pest remains to be seen. One note of interest in this connection is furnished by Stephens (MS), who says that at Silsbee, while occasionally getting into the fields, the Round-tails were easily drowned out. As far as known to us, this species never drinks water even when within reach of it: In most parts of its range and at most seasons of the year water is secured only through chemical elaboration from its dry or nearly dry food materials. It is currently reported by the farmers in Imperial Valley that the native desert animal life quickly disappears when the land is brought under cultivation and especially irrigation. 


\title{
DEATH VALLEY ROUND-TAILED GROUND SQUIRREL.
}

\author{
Citellus tereticaudus eremonomus Elliot.
}

Other names.-Death Valley Spermophile; Citellus eremonomus.

Field characters.-Exactly as for the Yuma Round-tailed Ground Squirrel.

Description.-As for the Yuma and Palm Springs Round-tailed Ground Squirrels, but coloration decidedly darker than in either, near wood brown. This feature is characteristic in all of the eight skins of eremonomus at hand.

Color variations.-The time of the spring molt is indicated by a specimen of date April 10, in which new summer pelage shows on the head and rump; an example of May 3 is in absolutely new summer pelage except, of course, for the tail. One specimen bas a bobbed tail, with an abnormal tuft of hairs at the end, showing conspicuously a band of black and then a terminal band of white. Most of the skins show a curious spotting of the rump which is clearly not due to color markings on the hairs, but to places where hairs are absent, so that the dark-colored skin and dark bases of adjacent hairs show through. These may indicate scars from insect bites.

Measurements.-Average and extreme measurements, in millimeters, of eight adult female specimens from Death Valley are as follows: total length, 249 (240-255); tail vertebræ, 91 (87-93); hind foot, 35 (34-36); ear from crown, 2.1 (2.0-3.0) ; greatest length of skull, 36.0 (34.8-36.6); zygomatic breadth, 22.5 (22.0-23.4); interorbital width, $8.7(8.3-8.8)$. No males are available.

Weights.-Average and extreme weights, in grams, of eight adult females from Death Valley are as follows: 144.3 (121-158). The average, in ounces, is 5.1.

Type locality.-Furnace Creek [Ranch], Death Valley, Inyo County, California (Elliot, 1903, p. 243).

Distribution area.-Floor of Death Valley, in Inyo County. Life-zone, Lower Sonoran. Only known locality of occurrence, vicinity of Furnace Creek Ranch (Greenland Ranch), -240 to -175 feet altitude. Apparently cut off from its nearest relative, tereticaudus proper, by the elevated rim of the Death Valley basin.

Specimens examined.-A total of 8, all from the near vicinity of Furnace Creek Ranch, -178 feet, Death Valley, Inyo County.

As far as known, this race of Round-tailed Ground Squirrel is limited in its distribution to the bottom of the deep sink known as Death Valley, and even there to the belt of mesquites immediately around the margin of the alkali flats at the lowest level. The entire habitat of this Death Valley subspecies thus lies below sea level, a distinction probably not shared by any other rodent in America.

Our experience with this squirrel was obtained during April and early May, 1917, in the immediate vicinity of old Furnace Creek Ranch, now known as Greenland Ranch. The animals at the time of our visit were not invading the cultivated land, though we were assured by the foreman that they had come into the alfalfa fields in previous seasons. Since this was the type locality of the subspecies, special efforts were made to obtain a series of specimens. The animals were not abundant, and proved practically impossible to trap. Shooting was resorted to, though with but little better results. The following notes were made on April 10 by the senior author while hunting them.

During a two hours hunt at midday at least five individuals were heard on the mesquite-crowned sand dunes within a mile southwest of the ranch. The warmth had seemingly brought them out, for the previous two or three days had been relatively cool, and none had been seen. A temperature of over $100^{\circ}$ in the shade seemed to be necessary to 
bring the animals out into full activity. "I caught sight of one standing upright at the mouth of its burrow, squeaking, and of two others running over the sand beneath the trailing green mesquite branches. The lines of footprints in the sand centering at the mouths of their burrows are diagnostic. The animals are extremely shy, going below ground at the slightest alarm. By standing ten minutes or so 'at attention' about fifteen yards from the mouth of a burrow down which one vanished, I finally saw the top of its head reappear to the level of its eyes. This position was maintained for many minutes, mntil the animal suddenly raised its whole head and neck into view, when I shot it.

"Later, while I was lying prone on the sand under a mesquite, one came up to within eight feet of me and gave its shrill, wiry ery, or squeak. A mere movement on my part, and it vanished, quick as thought." It was found that a little "screeping" (lips to back of hand) would often bring one of the squirrels stealthily investigating through the brush, provided the observer kept perfectly motionless himself and was possessed of patience. The squirrel would sometimes squeak, apparently in answer, and thus be called into very close "aux" range. The burrows were as a rule located in the periphery of a large mesquite clump, where they were shaded by the radiating leafy branches which trailed down the sandy slopes. Not more than three burrows certainly of this rodent were to be found about any one clump.

The mesquites during early April were just coming out into full new foliage. The stomachs of the squirrels shot were distended with masses of finely chewed mesquite leaves and nothing else. This, in fact, was absolutely the only kind of vegetation anywhere in sight for hundreds of yards. In one instance the total weight of the freshly killed animal was found to be 154.5 grams; of the full stomach alone, 28.7 grams, or 19 per cent (near one-fifth) of the total weight. In other words, a Death Valley Round-tailed Ground Squirrel may eat close to one-fourth its own weight of green mesquite leaves.

No young were seen by us up to the time of our departure, but they are probably born about the first of May. Tro old females captured April 10 and 12 contained four and three embryos, respectively.

\section{PALM SPRINGS ROUND-TAILED GROUND SQUIRREL.}

\section{Citellus tereticaudus chlorms Elliot.}

Other names.-Pale Spermophile; Citellus chlorus.

Field characters.-Exactly as for the Iuma Round-tailed Ground Squirrel.

Description.-As for the Iuma Round-tailed Ground Squirrel, but tone of coloration more grayish, avellaneous rather than light pinkish cinnamou. This difference holds througl all pelages and gives the impression of an olive-colored animal, when close comparisons are made with series of the other related ground squirrels.

Color variations.- Specimens showing the spring molt to be in process bear dates from March 29 to as late as June 3. As with the other races of tereticaudus the pelage on the tail is not replaced during the spring molt and it becomes greatly faded and worn. In extreme cases the tail with its shortened, singed-looking hairs is a dirty pale bromn color throughout, and as slender as a wood-rat's tail. The summer 
coat is so short and thin that any scars there may be in the skin show through as dark spots. These appear irregularly on certain specimens, usually those which examination of the teeth shows to be the older individuals.

Measurements.-Average and extreme measurements, in millimeters, of twenty adult specimens from Whitewater, Palm Springs and Mecca, in Riverside County, are as follows: Ten males: total length, 241 (220-251); tail vertebræ, 90 (79-97); find foot, $36(35-40)$; greatest length of skull, 36.6 (35.2-38.9) ; zygomatic breadth, $23.0(21.6-24.6)$; interorbital width, $8.9(8.0-9.7)$. Ten females : total length, 240 (229-264) ; tail vertebræ, 89 ( $80-102)$; hind foot, 35.7 (34-39) ; greatest length of skull, 36.1 (35.6-37.5) ; zygomatic breadth, $22.8(22.0-23.4)$; interorbital width, S.S (8.6-9.4).

Type locality.-Palm Springs, Riverside County, California (Elliot, 1903, p. 212).

Distribution area.-The northwestern arm of the Colorado Desert between Salton Sea and San Gorgonio Pass (see fig. 1S). Life-zone, Lower Sonoran. More specifically, the Coachella Valley, entirely within Riverside County, from Niecca northwest. to Whitewater Station; altitude from -200 to 1,130 feet.

Specimens examined.-A total of 41 from the following localities, all in Riverside Connty : Palm Springs, 6 ; Whitewater Station, 18; Mecca, 17.

This race of Round-tailed Ground Squirrel was first made known from specimens collected in the vicinity of Palm Springs, out on the Colorado Desert near the northeast base of San Jacinto Peak. Subsequent exploration has shown it to be limited to the relatively small area of flat desert lying between Salton Sea and the upper part of San Gorgonio Pass, and shut in narrowly by the mountain walls on either side.

The slight features by which this subspecies is distinguishable from the Yuma Round-tailed Ground Squirrel of the Imperial Valley southeast of Salton Sea may be inferred to have arisen as a result of the action of the body of water which formerly filled the Salton Sink to sea level in cutting off or isolating the animals in the northwestern arm of the Colorado Desert and thus giving them a chance to deverop peculiarities all their own. The ancient predecessor of the present Salton Sea is known to geologists as Blake Sea, and this inland sea extended from the base of the Chocolate Range of mountains on the northeast to the very foot of the Santa Rosa Mountains on the southwest, thus constituting an impassable barrier to any animal closely restricted, as is the Round-tailed Ground Squirrel, to dry, level, sandy ground. However this may have been, the Palm Springs subspecies now ranges down the Coachella Valley from the northwest nearly to the upper end of the present Salton Sea, in the vicinity of Mecca. One can imagine the animal life of the desert floor now retreating, now advancing, with the fluctuations of the old Blake Sea since the time it was first cut off from the Gulf of California by the slowly growing delta of the Colorado.

The general habits of the Palm Springs Round-tailed Ground Squirrel are probably closely similar to those of the Yuma and Death Valley animals. The first-named is fairly common locally, though it rarely forces itself on the attention; it has to be specially looked for. At Mecca in March and April (1908) one ol two were caught nearly every day in oat-baited rat-traps set on sandy mounds beneath mesquites. Yet the animals themselves were rarely seen. On April 26 one was surprised up in a mesquite; upon being shot it was foumd to have parts of a mesquite flower in its mouth. The senior anthor was told that at the experimental date farm near Mecea these squirrels had been seen eating the dates. 
At the railroad station of Whitewater this animal was found by museum collectors to be common, June 3 to 5 (1908), in a tract of sand dunes nearby. The shrill calls or whistles were heard frequently, and many of the squirrels were trapped. Some of these were young, onethird to one-half grown. The old males and part of the old females taken then were very fat; all the rest lean. A female taken at Mecea, March 27, was found to contain five large embryos. The extent of the breeding season is thus indicated. Doubtless but one litter is raised each year.

Search in the vicinity of Palm Springs in December and January of different years has failed to show the presence of these squirrels actively abroad; so that it is likely that they hibernate during midwinter. In 1916, Swarth (MS) found them out on February 4 in a tract of sandy soil about a mile east of the village. They oceurred in small scattered colonies, each "colony" marked by twelve to fifteen open holes on level ground among ereasote bushes. "Parts of the burrows were shallow, so that a person would sink through into them ankle deep." The animals when alarmed would scurry to their holes and disappear into them, but would presently poke up their heads and utter "faint little barks."

No information has come to us that would indicate any decided economic bearing on the part of the Palm Springs Round-tailed Ground Squirrel. Because of its dry-land preferences it is likely that reclamation and irrigation of the land would drive it away rather than attract it. Thus the reaction would be just the opposite to that in the case of the Oregon Ground Squirrel and similar species.

\title{
SIERRA GOLDEN-MANTLED GROUND SQUIRREL.
}

\section{Callospermophilus chrysodeirus chrysodeirus (Merriam).}

\author{
PLATE III.
}

Other names.-Gilded Squirrel; Gilded Ground Squirrel; Copper-headed Ground Squirrel; Copperhead; Yellow-headed Chipmunk, part; Golden Chipmunk; Sidestripe Ground Squirrel; Bummer; Trinity Ground Squirrel; Callospermophilus chrysodeirus trinitatis; Citellus chrysodeirus, part; Spermophilus chrysodeirus, part; Spermophilus lateralis; Callospermophilus lateralis chrysodeirus; Citellus chrysodeirus trinitatis; Tamias chrysodeirus; Tamias lateralis, part.

Field characters.-A medium-sized, ground-dwelling squirlel with conspicuous stripes along sides of body; whole head more or less deeply yellow or coppery red; build stout; length of body without tail about $7 \frac{1}{3}$ inches, with tail about $3 \frac{1}{2}$ inches more.

Description.-Adult in fresh late-summer pelage: Whole top of head and hind neck, orange-cinnamon; cheek and side of neck to shoulder, ochraceous-tawny; side of suout, area around eye, ear and spot behind ear, ochraceous-buff of varying intensity; whiskers black. Two black stripes and an intervening buffy white stripe on each side of body; the whitish stripe longest, extending from shoulder over side of rump nearly to base of tail; the lower black stripe next in length, the upper shortest and it and its fellow of opposite side separated by a median band of grizzled light cinnamon-brown; this band extends from between shoulders backwards to base of tail, and expands on rump to cover flanks; side of body below lower black stripe, light buff, obscured by dusky hair-tippings. Upper sides of feet light buff: 
claws blackish-brown, horn-color at tips; soles of hind feet naked nearly to heel. Chin and throat and insides of forelegs and thighs buffy white; belly with laairs extensively slaty brown at base, tipped with whitish; in other words, whitish with much slaty brown showing through. Tail well-haired, flat in form, broadest in middle portion, tapering somewhat toward end; in color, as viewed from above, chiefly black, with a margin of ochraceous-buff; there is considerable mixture with cinnamon-brown toward base, however, and separation of the hairs discloses the deeper-lying hazel color of their roots; lower surface of tail centrally solid hazel, paling to ochraceons-tawny at base of tail, then a zone of black, and then an outer fringe of bright ochraceous-buff. The body side-stripes are sharply defined along their edges, but at their ends fade out gradually; also the reddish of head blends by degrees with colors of body adjacent.

Color variations.-As far as we can see there is no difference in coloration between male and female, in spite of the extraordinarily bright pattern of coloration in this species. The young, even third-grown ones, are very similar to the adults in pattern, the difference consisting only in paler tones of color, especially about the head. There is, however, considerable change in the depth of coloration with season. In the spring and early summer the head region is much paler than in late summer and fall, and there is much other evidence of fading and wear to which the pelage has been subjected. In June specimens the head is pale cinnamon-buff.

As far as we can determine from the collection of specimens studied there is but one thorongh-going molt each year and this takes place in June and July. The process is gradual. The exchange of old hair for new begins first on the head and progresses backwards; but specimens often show a patchy coat, with areas of dense new hair on the head or back surrounded by old worn hair.

We are unable to make out a distinguishable race from the Trinity Mountain region, trinitatis of Merriam, 1901, p. 126, type from "Trinity Mountains east of Hoopa Valley, California (altitude 5,700 feet)." The characters assigned, of color and size, are not borne out in our large series of specimens from the Trinity region as compared with series from the northern Sierra Nevada. There is, however, a slight tendency towards paling of colors in chrysodeirus at the sonthern end of the Sierra Nevada and along their east flank; for example, as slown by specimens from the east declivity of Kearsarge Pass, west of Independence. This modification is evidently in the direction of perpallidus.

Measurements.-Average and extreme measurements, in millimeters, of twenty full-grown specimens from the west slope of the high central Sierra Nevada are as follows: Ten males: total length, 272 (253-290); tail vertebræ, S9 (75-104); hind foot, 41 (3S-43); ear from crown, 15.7 (11.0-19.0); greatest length of skull, 44.0 (42.2-46.2) ; zygomatic breadth, 26.6 (25.2-28.2); interorbital width, 10.4 (9.5-11.1). Ten females: total length, $266(243-285)$; tail vertebræ, $83(67-100)$; hind foot, $41(39-44)$; ear from crown, $16.1(13.0-21.0)$; greatest length of skull, 42.7 (41.0-44.1) ; zygomatic breadth, 25.9 (25.0-27.1) ; interorbital width, 10.3 (9.2-11.0).

It would appear from the above figures that in males the tail averages a little longer than in females. The skulls of old individuals, particularly males, relative age being estimated by degree of wear on the crowns of the molar teeth, show greatest size, particularly as regards zygomatic breadtl and heaviness of rostrum. Old skulls also show wider brain-case, broader jugals, and stouter postorbital processes.

Weights.-Average and extreme weights, in grams, of twenty full-grown specimens from the west slope of the high central Sierra Nevada are as follows: Ten males, 181 (155-218); ten females, 199 (136-245). Averages, in ounces: males, about $6 \frac{1}{2}$; females, about 7 .

The heaviest example (245 grams) was a pregnant female. Males average heavier in the fall, when they are fat, than in early summer.

Type locality.-Fort Klamath [mountains near], Klamath County, Oregon (Merriam, 1890 , p. 19).

Distribution area.--Upper coniferous belt (Canadian and Hudsonian life-zones, less commonly down into Transition) along the Sierra Nevada, south as far as Cannell Meadows, in extreme southern Tulare County; north throngh the Mount Lassen country to Mount Shasta, and thence west through the Trinity, Scott and Salmon Mountains (Mus. Tert. Zool.) to extreme eastern Humboldt County (Merriam, 1901, p. 126) : also on the Siskiyou Mountains, along the Oregon border of western Siskigou County (Merriam, 1901, p. 126) ; on the mountain mass to the 
south of the Trinities, in the vicinity of Yolla Bolly Mountain, where Humboldt, Tehama and Mendocino counties adjoin; and on the Warner Mountrins, in eastelu Modoc County (MI Us. Vert. Zool.). The range of the Golden-mantled Ground Squirrel in northern California is probably less continnous than indicated on the map (fig. 24), there being sequestered colonies on detached mountains along with similarly isolated representations of other boreal animals and plants.

Altitudinally, this squirrel extends regularly to above timber-line, where the mountains are high enough for this, and downwards to the lower edge of the chinquapin belt, that is, scarcely as far as the yellow pines or Douglas firs. At the farthest south, in the Mount Whitney region, it has been noted as high as 11,500 feet. while downwards it was not ser' below 7,000 feet. In the latitude of Yosemite, the highest point at which it was observed was 10,700 feet, and the lowest, Merced Grove of Big Trees, 5,500 feet. In the Trinity region, the lowest occurrence noted was at 4,500 feet altitude. There is thus a notable lowering of altitudinal limits with increased latitude.

Specimens examined.-A total of 259 , from the following localities in Califolnia : Modoc County: ten miles northwest of Canby, 1; Sugar Hill, 11; Parkel Creek and North Fork Parker Creek, Waruer Mts., 9; War'ren Peak, Warner Mts., 7 ; Dry Creek, Warner MIs., 1. Siskiyou County: head of Little Shasta River, northeast base Goose Nest Mt., 2; Mount Shasta, 10; Kangaroo Creek, 1; Wildcat Peak, 3; Jackson Lake, 5; Saloon Creek Divide, 11; Castle Lake, 2; head of Rush Creek, 6; South Fork Salmon River, S. Trinity County: Bear Creek, 11; North Fork Coffee Creek, 3 ; head of Grizzly Creek, 5; one-half mile south of South Yolla Bolly Mt., 3. Lassen County: Eagle Lake, 2; Horse Lake, 1. Tehama County : two to four miles south of South Tolla Bolly Mt., 19; Mount Lynn, 2. Plumas County : Mohawk, 1. Sierra County : near Sierraville, 1. Nevada County : Independence Lake, 5. Placer County: Tahoe Valley, 2; Cisco, 13; two miles west of Soda Springs Station, 1. El Dorado County : Mount Tallac, 1. Mono County : Leevining Creek, 1; Walker Lake, 1; Bloody Canyon, 1. Tuolumne County: Ten Lakes, 1; Glen Aulin, 1; 'Tuolumne Meadows, 4; head of Lyell Canyon, 2 ; Aspen Valley, 2. Mariposa County: Vogelsang Lake, 1; Porcupine Flat, 3; one mile east of Merced Lake, 1; neal Mono Meadows, 2; Mount Clark, 1; Merced Big Trees, 5; East Fork Indian Canyon, 1; Chinquapin, 3. Inyo County: Little Onion Valley, 1; Onion Valley, 4; Hockett 'Trail (neal Carıoll Creek), 2; Little Cottonwood Creek, 4; Cottonwood Lakes, 6. Fresno County: Kieal'sarge Pass, 5; Bullfrog Lake, S; Bubbs Creek, 1; Horse Corral Meadow, 2. Tulare County: Siberian Pass, 1; west slope Cirque Peak, 1; Whitney Creek, 3; Whitney Meadows, 13; west slope Olancha Peak, 1; Dry Meadows, 1; Monache Meadows, 7; Jackass Meadows, 14; Sirretta Meadows, 3; Caunell Meadows, 5.

Of all our ground squirrels the Golden-mantled is the most brilliantly colored. This rather bookish name for the animal is a translation of the scientific name of the species, chrysodeirus; the more commonplace appellations locally employed, "Copperhead" or "Yellow-headed Chipmunk," serve just as well to set forth the conspicuons feature of coloration. Because of the bright colors and especially the striping of the body (see fig. 20d), this ground squirrel is often called "chipmunk;" but the latter name applies to a quite different group of animals which are slenderly built, agile, with long tails, and more numerous body stripes which involve the head as well as the body.

The Golden-mantled Ground Squirrel is truly a ground squirrel in essential features of appearance and behavior as well as structure. Although it lives for the most part in forested regions, it keeps strictly on the ground when traveling or feeding, and only ascends rocks or logs when seeking a lookout station. The species, including its three subspecies in California, is confined to the higher mountains. One does not meet with it, in climbing the slopes, usually until well through the yellow-pine belt. Individuals begin to appear with the firs, and from there on to the upper limit of timber this species constitutes one of the most conspicuous features of the life of the forest floor. Here 


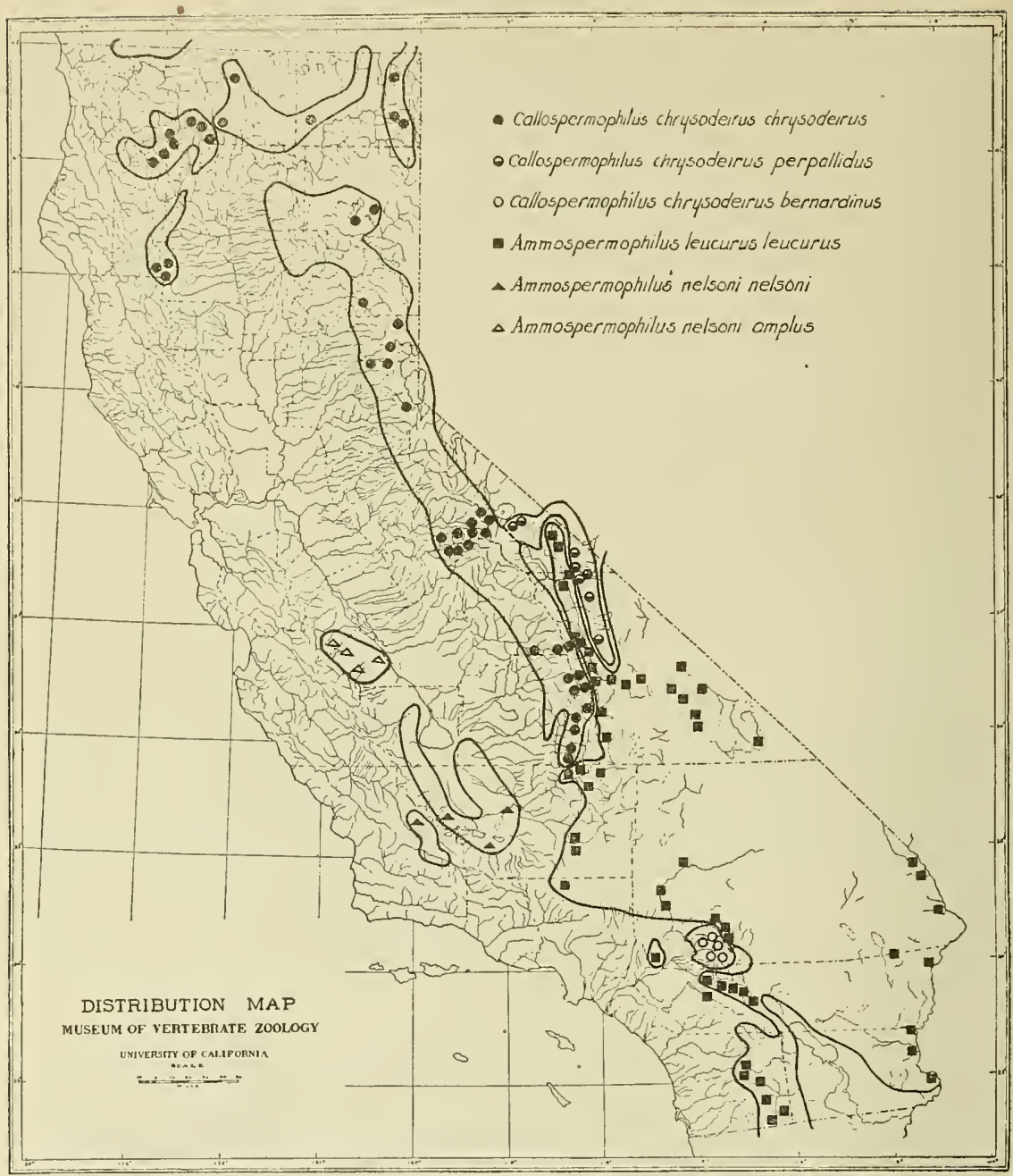

FIG. 24. Map showing California distribution of the golden-mantled and antelope groups of ground squirrels. The spots represent locaities from which actual specimens have been examined.

the animals are to be seen scurrying across open spaces to their burrows, just in front of the mouths of which they almost invariably stop a moment before plunging out of sight, displaying then to full advantage their color pattern. If the observer traverses their domain quietly, he may suddenly discover individual squirrels intensely observing him from perehes on the tops of boulders or logs. There they sit in unostentatious, hunched-over postures, blending so well with the background that they are often passed by altogether unnoticed. The element protecting them from observation most, at such times, seems to be their faeulty for keeping absolutely still. 
Rarely do Golden-mantled Ground Squirrels assume the upright picket-pin pose so characteristic of some others of the species. They most often maintain crouching attitudes when at rest. When running, the gait is clumsy, as compared with the chipmunks usually to be seen close at hand. The tail is rather longer than in others of the smaller sized ground squirrels, and is more conspicuorsly displayed, often up over the back, or, when running, either held vertically or frisked violently fore and aft. This squirrel seems to be, as a rule, almost devoid of voice. As far as our own experience has gone, there is only a single chirp of alarm, not loud nor high-pitched, and even this is uttered but rarely. One observer (W. P. Taylor, MS) has been fortunate enough to run across a talkative individual. This animal was watched as it sat bolt upright on a log uttering a "sharp call note, to-chick, sometimes varying this to tachack, p'r'r'r'r." A "general squirrel-like quality" was ascribed to these notes. At each utterance a violent flirt of the tail was given.

Speaking of habitat again, the Golden-mantled Ground Squirrel shows decided preference for rocky slopes or forest floors littered with logs, but at the same time without heavy undergrowth. Open ground is preferred; yet it keeps out of large grassy meadows, save as visiting the margins of these where they adjoin the woods. Again we see adjustment so that each of the different kinds of rodents keeps to a separate forage area without undue waste of energy in competing with another. In the higher, rougher parts of the mountains we have often found the Copperheads inliabiting rock slides. Here, as in the other places, where there are logs or scattered rocks, the object appears to be to secure protection for their burrows, so that these can be located beneath heavy objects and thus prove difficult or impossible for badgers, coyotes or bears to dig out.

The mouths of the burrows vary in diameter from 2 to $2 \frac{1}{2}$ inches, and the direction taken is usually steeply down into the ground for a foot or more. Unfortumately, we have never availed ourselves of an opportunity to dig out the burrow system of a Golden-mantled Ground Squirrel. We infer it to be simple and relatively short, for two reasons: the mounds at the mouths of the burrows are usually small in quantity of earth composing them; and the big roots, logs or rocks beneath which the burrows in practically all cases lead, would seem to do away with the need of an extensive and deeply penetrating system so as to secure safety from enemies which pursue their prey by digging.

The Golden-mantled Ground Squirrel is a spermophile in the truest sense of the word; it is preëminently a gatherer and eater of seeds, and most of its time aboveground seems to be occupied in diligent search for this sort of food. The cheek-pouches in this squirrel are developed to a maximum degree, and it is no uncommon thing to see an individuai leturning to its burrow from a foraging expedition with its two pouches so distended with seeds that the head seems double its ordinary width. We have counted 636 seeds from the two pouches of one squirrel.

Some seeds identified in cheek-pouch contents saved are: Goose grass (Galium aparine), rice-root lily (Fritillaria sp.), pentstemon (Pentstemon azureus), and silver pine (Pinus monticola). In the late summer and autumn months great activity is shown in garnering chincuapins, and there seems good reason to believe that large stores 
of these and various seeds are then housed away in the ground for use the following spring when the animals come out of libernation and food is difficult to find otherwise. One individual had its cheek-pouches crammed with fragments of a brown-colored fungus such as forms bracket-like outgrowths on the bark of dead trees and old logs. Our experience shows this article of diet to be much sought after by members of the squirrel tribe generally.

Then, too, the Golden-mantled Ground Squirrel eats meat, and even carrion, as we can testify from the persistency with which our meatbaited steel traps set for coyotes and other carnivores are sprung by the Copperheads. Indeed, it seems reasonable to infer that this ground squirrel would lose no opportunity to appropriate to its use the dead remains of any sort of animal. Around camp sites we have often received good evidence of the omnivorous nature of the Copperhead's diet from seeing them gathering the scattered barley from the ground where the horses had been fed and then gleaning the scraps of cooked meat as well as bread crumbs from our own table near by. In one case a "Callo" came again and again to gnaw at a bacon rind. The young, but a third grown, show almost as much industry in carrying away food as do the adults.

That not all the food gathered, over and above what is immediately eaten, is carried to some definitely located storehouse, is shown by an observation by W. P. Taylor (MS). On the summit of Cloud's Rest, Yosemite Park, a "Callo" was encountered which was so used to the almost daily visits of people as to have become remarkably tame. It would run up to within three feet of a person, take the dried fruit thrown down for it, stuffing its cheek-pouches to capacity, and then run off just a little ways. After digging out a little hollow in the ground with its front feet, it placed the fruit therein and proceeded to cover it up with earth, using its front feet again. Sitting over the spot, it reached out to gather in additional loose stones until the cache was effectually concealed. Such hiding places as these are probably used only temporarily, at times when an abundance of food is suddenly available, to be stowed safely from someone else's reach as soon as possible, and later reclaimed for more permanent salvage.

The young are born mostly in July, but as early as the last of June at the lowest altitudes of occurrence, and as late as the first week of August up near timber line. Young one-half grown were taken on Cannell Meadows, 7,500 feet altitude, Tulare County, on July 7, 1911; and young but a third grown were taken at Cottonwood Lakes, 11,000 feet, near Mount Whitney, August 31, 1911. These dates are the extremes in the considerable series we lave for time of appearance of young. Young come above ground when they are as small as onefourth adult size (as determined by weighing). There is but one litter each year. This probably averages close to five in number. Six females captured along the central Sierras, of dates June 12 to 28 , contained 5,2,5,6,6 and 5 embryos, respectively. The number of mammie (represented by nipples) is either four pairs or five pairs, but this number is not, as some persons think, any index to the number of young born.

The enemies of this squirrel probably include most of the carnivores of the higher mountains. Hair of a "Callo" was found in the feces 
of a Mountain Coyote (Canis latrans lestes) in the Yosemite National Park. Near Monache Meadows, in the Sierras of eastern Tulare County, one of the writers saw a Mountain Weasel (IIustela arizonensis) in full pursuit of a "Callo" across open ground in the full sunshine of the bright forenoon of August 4, 1911. The squirrel was overtaken by the weasel, and what happened transpired so swiftly that no details were observable. A gunshot terminated the episode, and the "Callo" was found already stone dead, with two tooth-punctures on each side of the nape of its neck.

The Golden-mantled Ground Squirrels hibernate regularly. They doubtless construct warm, dry nests underground, as individuals have been seen gathering soft materials and carrying these to their burrows. In one instance an individual was seen to pick up a piece of brown paper and after tearing it with its teeth and forepaws, stuff it into its cheeks and disappear into a burrow (C. L. Camp, MS). By the last of August these ground squirrels begin to aequire fat, and during September and October they are simply "rolling in butter," as the saying goes. This seems to be in preparation for their long period of dormancy, which extends from the last of October to the middle of April.

Exact dates of going into, and coming out of, their winter sleep are not available to us. But in the Yosemite region in 1915 individuals were seen abroad in the Canadian life-zone commonly up to October 18; on October 30, in the same zone, but two individuals were seen on the same ground where very many were noted a month previously; and none at all were seen on subsequent dates when they were looked for at suitable altitudes. The estimate of April 15 as near the time of reappearance in the spring is based on what we have been told by trappers and forest rangers, and their statements were only from memory.

Since the territory inhabited by the Golden-mantled Ground Squirrel is practically altogether above the altitudinal limit of cultivation by man, this species rarely figures as anything worse than a camp-robber or "bummer" (see fig. 20d). Te have heard packers complain of its proclivities in the way of carrying off grain or provisions from summer camps in the higher mountains. But the total destruction of property thus wrought can hardly be formidable, and compensating for it to some degree must be counted the added animation lent to the mountain scene by the presence of these pleasing rodents.

\section{INYO GOLDEN-MANTLED GROUND SQUIRREL.}

\section{Callospermophilus chrysodeirus perpallidus Grinıeli.}

Other names.--Sierra GoIden-mantled Ground Squirrel, part; Yellow-headed Chipmunk, part; Callospermophilus chrysodeirus, part; spermophilus chrysodeirus, part; Citellus chrysodeirus, part.

Field characters.-Exactly the same as for the Sierra Golden-mantled Ground Squirrel, save for pallor of coloration.

Description.-Adult in fresh late-summer pelage: Pattern of coloration and chief features throughout precisely as in the Sierra Golden-mantled Ground Squirrel, but general tone of coloration paler; middle of back, rump and sides tending towards 
asliy, head less richly coppery, and under surface of body and upper surfaces of feet whiter; under surface of tail medially ochraceous-tawny. Because the lighter colors are paler in tone, the jet black side-stripes stand out with greater sharpness than in the Sierran race.

Color variations.-As in the Sierra Golden-mantled Ground Squirrel. In some specimens in freșh pelage the throat is pure white w'thout a tinge of buff. Halfgrown young just out of their nest-burrows show the characteristic paleness of their subspecies to as great a degree as adults in new coat. The pallidness of the adults in old worn breeding dress is greater in degree than in the Sierran race, evidently due to the greater bleaching effects of the more intense sunlight and dryness to which the Inyo animals are exposed. The innate paleness of the Inyo race is thus accentuated by external factors.

Measurements.--Average and extreme measurements, in millimeters, of twenty fullgrown specimens from the White Mountains, Mono and Inyo counties, are as follows: Ten males: total length, 26S (260-279); tail vertebræ, 92 (80-105); hind foot, 40 (3S-43) ; eal from clown, 13.4 (11.0-15.0); greatest length of skull, 42.9 (42.044.0) ; zygomatic breadth, 26.2 (25.0-26.9) ; interorbital width, 10.0 (9.0-11.3). Ten females: total length, 264 (254-286) ; tail vertebræ, 85 (78-89); hind foot, 38 (36-42) ; ear from crown, 13.3 (10.0-16.0) ; greatest length of skull, 41.4 (39.6$42.3)$; zygomatic breadth, 25.9 (25.0-26.6) ; interorbital width, 9.8 (9.3-10.2).

As will be seen from the above measurements in comparison with those given for the Sierran race, there are no important size differences between perpallidus and chrysodeirus; indeed it seems likely that, with large enough series, such discrepancies as are here in evidence would disappear altogether. The same variations due to age and sex seem to be present.

Weights.-Average and extreme weights, in grams, of twenty full-grown specimens from the IVlite Mountains, Mono and Inyo counties, are as follows: Ten males, 182 (166.5-199.5) ; ten females, 160 (141.0-209.1). Averages, in ounces: males, about $6 \frac{1}{2}$; females, about $5 \frac{1}{2}$.

There were no gravid females in this lot. All were taken before August 10 and so none had become very fat. These facts may account for the lesser weights than shown for the Sierran race.

Type locality.-White Mountains at 10,300 feet altitude, near Big Prospector Neadow, Mono County, California (Grinnell, 1918, p. 429).

Distribution area.-The upper portions of the arid mountain ranges of extreme eastern California lying east and north of Owens Valley, namely the Inyo and White Mountains, and the mountain mass lying southeast of Mono Lake. Northernmost station, Mono Craters, Mono County (Mus. Vert. Zool.) ; southernmost, summit of Inyo Mountains east of Lone Pine (Elliot, 1904, p. 28S). Along this extent of territory the distribution of the animal is, not continuous but is intermpted at the lowermost gaps between the Inyo and White Mountains and at the extreme head of Owens Valley. Zonally, this race belongs to Boreal, but it extends down locally as low even as Upper Sonoran (see fig. 23). In other words, it extends from above timberline down to as low as $\mathbf{7 , 0 0 0}$ feet altitude (lower edge of piñons), the latter level for it being recorded from the bottom of Silver Canyon east of Laws. The highest observed station of occurrence is McAfee Meadow, 11,600 feet, near White Mountain Peak (Mus. Vert. Zool.).

Specimens examined.-A total of 50, from the following localities in California : Mono County: Mono Mills, 4 ; Mono Craters, 1; McAfee Meadow, White Mts., 7 ; Big Prospector Meadow, White Mts., 22; Cottonwood Yreek, White Mts., 1. Inyo County: Roberts Ranch, Wymau Creek, White Mts., 2 ; Silver Canyon, White Mts., 4 ; Black Canyon, White Mts., 5 ; Mazourka Canyon, Inyo Mts., 4.

This is simply a pale desert-range race of Golden-mantled Ground Squirrel, probably cut off but incompletely from its near relative, chrysodeirus, of the Sierra Nevada. There can hardly be expected to be any decided differences in habits between the two; yet the different "setting" of perpallidus-exceedingly dry, rocky slopes, with only sparse timber at best-has left in our minds an impression of distinctness. This only goes to show that we cannot conveniently, nor should 
we properly (from a scientifie standpoint), consider any animal altcgether apart from its normal surroundings.

In the Inyo Mountains this squirrel was found by H. S. Swarth (MS) to range from the level of the lowest piñons in Mazourka Canyon, about 7,500 feet altitude, to the highest summit visited by him, 10,500 feet. In the White Mountains, east of Laws, the senior author found it to range down Silver Canyon to as low as 7,000 feet altitude, and here this and the Antelope Ground Squirrel of the lower country overlapped in their ranges to a small degree. The "Callos," in such precipitous canyons as Silver Canyon, were essentially "rock" squirrels, in that they had their retreats in the slides of shale rock at the bases of the cliffs and even in the broken rock outcrops far up the eanyon walls. Through and along these they clambered, a bit clumsily perhaps, but without loss of foothold so far as was seen.

Higher up, on the lofty rolling plateau forming the summit of this mountain range, the Golden-mantled Ground Squirrels were extremely abundant along the edges of the stunted forests of foxtail and lodgepole pines, and even far from timber ont on the sagebrush flats, but in the latter locations there were always near at hand fractured granite outcrops which afforded safe retreats. Where there were grassy meadows the animals foraged all over them. It oceurred to the observer that here in the White Mountains there was but this one species of ground squirrel and that it therefore had the run of the whole place, as it were, without meeting with any competitor, as is the case in the Sierras and elsewhere. This would account for the facts as observed, namely, that in the White Mountains the Copperheads were extraordinarily abundant and ranged widely into all sorts of associations.

Our lines of rat-traps baited with rolled oats brought in many "Callos," even youngsters but a third grown, and it was praciically impossible to keep steel traps set during the day, as the bait, consisting of the bodies of the various birds and small mammals prepared f $n$ : specimens, seemed to be especially attractive to the squirrels. Wherever the traps were set, they would be searehed out and unvittingly sprurs as the squirrels scrambled over them in quest of the bait. It seemec. impossible that the "Callos" could have located some of the settings except through scent, and it is reasonable to suppose that the sense of smell is employed not only in seeking meat but when searching for the bulbs of certain plants.

Young were out in numbers the last week of July at the 10,000-foot level, being then one-third to one-half grown. Lower down, in Black Canyon at 8,000 feet altitude, half-grown young were seen on July 5 (1917); and at 10,500 feet altitude, on Cottonwood Creek, third-grown young were noted on August 8. This shows the usual variation of appearance of young with altitude, which of course has to do with advance of the season, and so with temperature.

In Mazourka Canyon, Inyo Mountains, two females, each containing six embryos, medium-sized and small, respectively, were taken May 19 and 22 (1912). We found no evidence of litters of a larger number than six; and there is certainly no more than one litter per year. 


\section{SAN BERNARDINO GOLDEN-MANTLED GROUND SQUIRREL.}

\section{Callospermophilus chrysodeirus bernardinus (Merriam).}

Other names.-San Bernardino Ground Squirrel; San Bernardino Spermophile; Iellow-headed Chipmunk, part; Spermophilus bornardinns; Spermophilus chrysodeirus brevicaudus; Citellus chrysodeirns bcrnardinus; Callospermophilus bernardinus; Tamias ehrysodeins brevicaudus; Tamias lateralis, part.

Field characters. - The same as for the Sierra Golden-mantled Ground Squirrel. The slight shortness of tail characterizing this race is certainly not a sufficient difference for notice at any distance.

Description.-In all pelages : Coloration, as far as we can see after comparing large series of specimens, exactly as in the Sierra Golden-mantled Ground Squirrel. None of the paleness is apparent such as characterizes the Inyo race.

Variations.-Of the same sort as discussed under the Sierran race.

Measurements,- Average and extreme measurements, in millimeters, of twenty full-grown specimens from the San Bernardino Mountains are as follows: Ten males: total length, 260 (240-27S) ; tail vertebræ, 80 (68-90); hind foot, 40 (36-43); greatest length of skull, $43.5(42.0-45.6)$; zygomatic breadth, 26.6 (25.5 -27.6); interorbital width, 10.7 (10.1-11.3). Ten females: total length, 251 (236-271) ; tail vertebræ, TS (72-S6); hind foot, 38.5 (35-42) ; greatest length of skull, 41.8 (40.4-43.0) ; zygomatic breadth, 25.5 (24.2-26.S) ; interorbital width, 10.2 (9.7-10.S).

Unfortunately, ear measurements from fresh specimens are not available; but dried skins look to have decidedly smaller ears than in either the Sierra or Inyo race, this character being especially noticeable in the young. It will be noted from the above measurements in comparison with those given for chrysodeirus and perpallidus, that the body size of bernardinus is just the same as in the others, while the tail length is decidedly less. This, then, is the character of the subspecies bemardinus, shortness of tail; and it shows up well in a series of specimens, even very young ones. However, this difference in tail length between adults of bernardinus and of chrysodeirus averages but somewhat less than half an inch, and individual variation brings overlapping in a certain proportion of specimens. In other words, an extra shorttailed chrysodeirus might even have a longel tail than an extra long tailed bernardinus. The race bernardinus is but slightly and incompletely differentiated.

No weights are available for this subspecies.

Type locality.-San Bernardino Peak, San Bernardino Mountains, San Bernardino County, California (Merriam, 1893, p. 134).

Distribution.-Restricted to the relatively small area, not more than twenty-five miles in greatest width, comprised in the higher parts of the San Bernardino Mountains (see fig. 24). Belongs to the Boreal zone and upper part of the Transition. Extends up to the very summit of San Gorgonio Peak, 11,485 feet altitude, and down locally, as near Bear Lake, to 6,700 feet (Grinnell, 1908, p. 141).

Specimens examined.-A total of 84 , flom the following locailties, all in san Bernardino County, California: San Gorgonio Peak, 2; Dry Lake, 3; South Fork of Santa Ana River, 14; Sugarloaf Mountain, 2; Bluff Lake, 61; Bear Valley, 2.

Far separated by desert and lowland from the habitat of its near relative on the Sierras, the Golden-mantled Ground Squirrel of the San Bernardino Mountains has developed slight peculiarities which make it recognizable as a distinct race. It has the most restricted range, probably, of any species or subspecies of ground squirrel in the state. It seems strange that it should be wholly lacking as an inhabitant of the San Gabriel and San Jacinto mountains, so near by on either hand and seemingly of quite similar enviromment to the San Bernardinos. On the higher parts of the San Bermardino Mountains it is certainly not on the wane, but thrives greatly, perhaps outnumbering all the other members of the squirrel family put together. 
In July, 1905, we found the Golden-mantled Ground Squirrels especially numerous around Bluff Lake, altitude 7,500 feet. Here they were to be seen all over the floor of the pine and fir woods, foraging among the chinquapin and deer-brush thickets. None was ever seen to climb a tree, thongh individuals were often seen perched motionless on stumps, logs or boulders. No matter where encountered, they always sought safety in holes in the ground or in crevices among rocks. They were notably quiet animals, giving only occasionally a single sharp note of alarm, or else, rarely, a low chuckle.

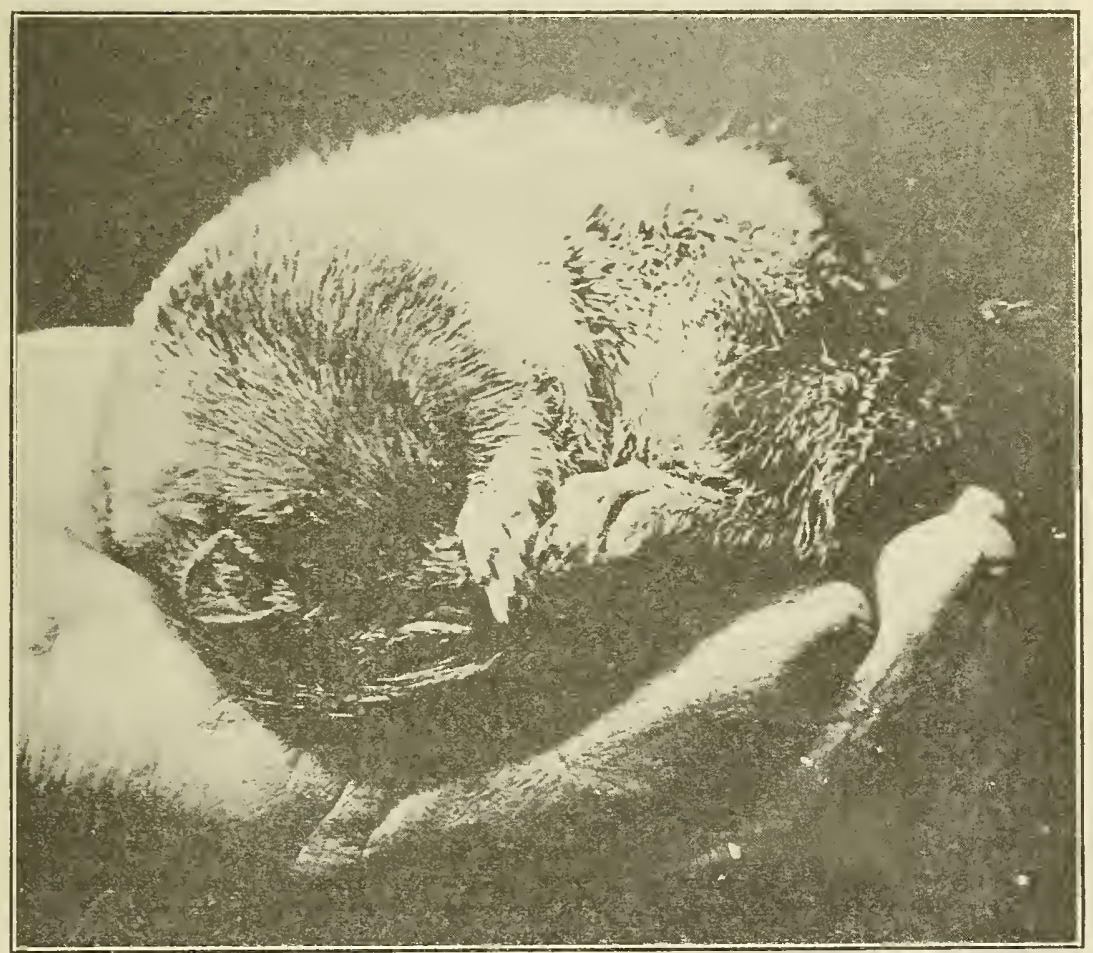

Fig. 25. San Bernardino Golden-mantled Ground Squirrel as taken from nest while dormant during period of hibernation. Note that the animal is curled into an almost globular shape, with head down and nose snuggled against stomach between fore and hind feet; tail curled underneath, partly concealing head.

Around Bear Lake the Yellowheads were common through the woods down to the water's edge. On the north slopes of Sugarloaf, on August 22, they were very busy gathering cheek-pouchfuls of seeds of a lupine, and the fruits of the deer-brush (Ceanothus cordulatus) and of a reddish-fruited currant (Ribes sp.). Elsewhere they were seen carrying to their burrows quantities of the green burrs of the chinquapin (Castanopsis sempervirens). The burrows usually opened out under logs, rotten stumps, or boulders. There was seldom any mound of earth to mark an entrance.

A female squirrel captured at Dry Lake, 9,000 feet altitude, on June 22, was found to contain four embryos. The young must have 
been born generally during the early part of July, in a few eases as late as early August, to judge from the relative sizes of the young seen abroad. The first to appear aboveground were noted on July 17 at Bluff Lake. These were about one-third grown and seemed quite able to forage independently of their parent. The latter paid no attention whatever to them, only giving the sharp alarm note if an intruder was sighted.

Two young ones trapped alive were taken home to Pasadena and kept in a eage. Early in the autumn one killed the other. The remaining individual survived for three years, latterly inhabiting a rock-pile in the yard and ranging freely where he would. Each winter he spent about seven months, October to April, inclusive, in hibernation (see fig. 25), with only occasional periods of activity for a day or two during spells of warm weather. It is interesting to note that this inclination to lie dormant was thus shown strongly at the low altitude of Pasadena, where the winter temperature searcely ever reaehed the freezing point. There could have been no practical reason for it as regards failure of food, for a supply was always provided the animal in abundanee. The annual program seems to require the dormant period, and this comes on at a regular time, and lasts the usual period, whether or not it happens to be essential to the survival of the individual. It is an inherited trait of the race.

\section{DESERT ANTELOPE GROUND SQUIRREL.}

\section{Ammospermophilus leucurus leucurus (Merriam).}

\section{PLATE V.}

Other names.-Antelope Chipmunk, part; Antelope Squirrel; Harris Chipmunk: White-tailed Spermophile; Charming Spermophile; Ammo; Tamias harrisi; હ̃ermophilus harrisii; Tamias leucurus; Citellus leucurus; Spermophilus leucurus; Citellus lencurus vinmulus; Citcllus vinnulus; Ammospermophilus lencurus vinnulus.

Field characters.-A small grayish brown ground squirrel with one white stripe on each side of body and with a short flat tail nearly always held cocked up over its rump so as to show the white under side conspicuously. Length of body alone about 6 inches, tail about $2 \frac{1}{2}$ inches more.

Description.-Adult in winter pelage: General color effect on upper surface from nose to base of tail light brownish drab, changing on shoulders, flanks and outer sides of fore and hind legs to light pinkish cinnamon. Close inspection shows a grizzling; due to variegation of colors on the individual hairs, these being, on middle of back for example, plumbeous at extreme base, then pale gray, then black, then brown, and finally white-tipped; some of the hairs on sides and rump are longer than the average and black to euds. A sharply-defined narrow white stripe on each side of body from shoulder to side of rump. Eyelids white; ears and sides of head buffy white; whiskers black. Whole lower surface of body, from chin to root of tail, silvery white, the bases of the hairs lead-color. Soles of hind feet densely white haired forward to tubercles (see fig. 26a), thence to balls of toes naked, and plumbeous in color in dried specimens; outer sides of hind feet and tops of fore feet tinged with pinkish cinnamon; feet otherwise dull white; claws blackish brown with pale horncolored tips. Tail broadly haired and blunt-ended, narrowed at base; abore mixed black and white, giving an iron-gray effect, but, analyzed in its terminal balf, an cutermost. white border is seen to be preceded inwardly by a black band, then by a white band, then centrally by black; toward the root of the tail, above, there is a tinge of pinkish cinnamon, this overlaid with a grizzling as on the back. Under 


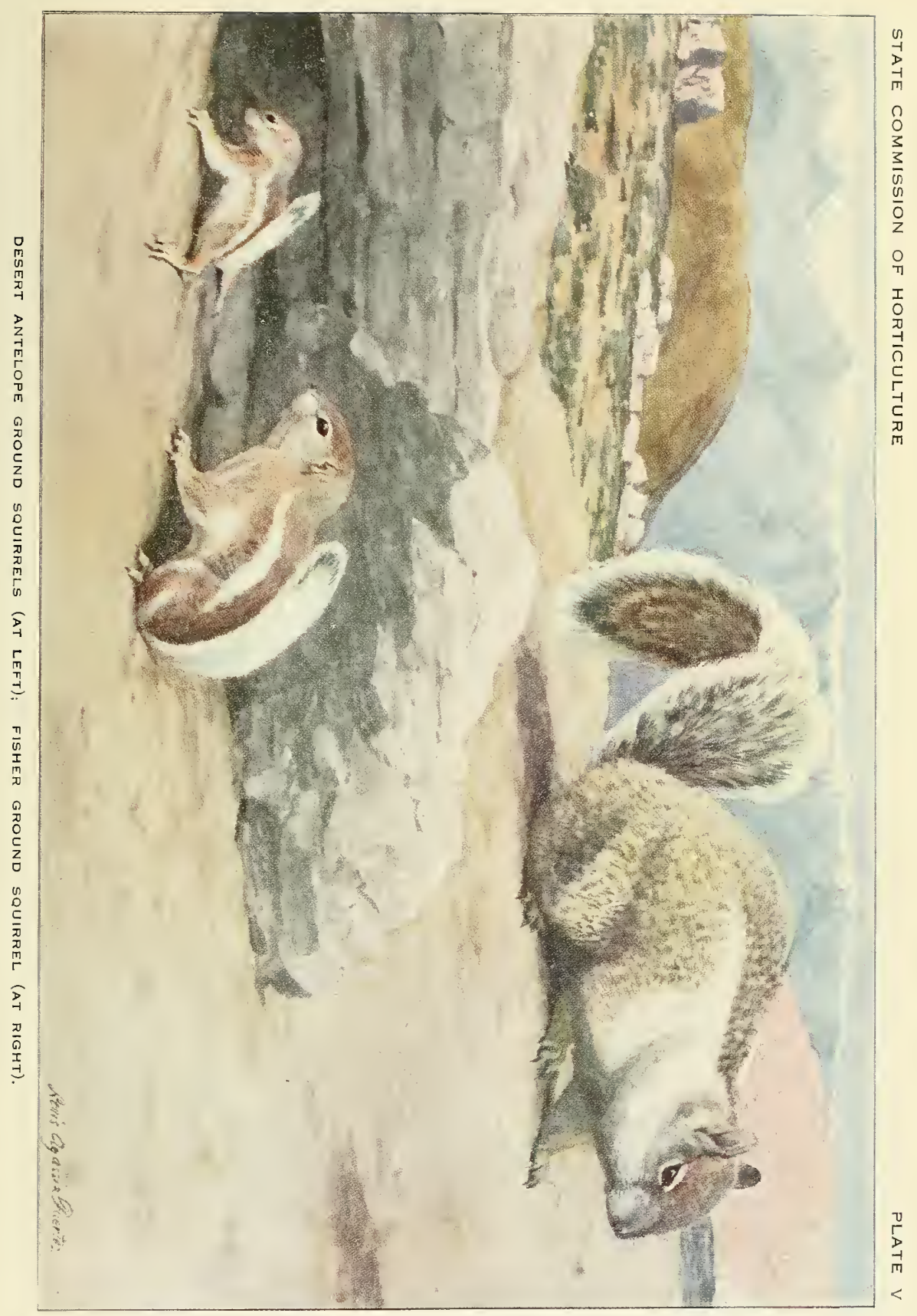



surface of tail broadly pure creamy white, with an outer black border around the terminal half, and succeeding this a white fringe.

Adult in summei pelage: Coat short and harsh instead of long and silky. General pattern of coloration as in winter, but tone of upper surface more buffy, especially so on top of head; hairs on whole lower surface pure white to bases (no lead-color) ; tail as in winter.

Color variations.-The sexes are alike in coloration. The young closely resemble summer adults save that the pelage is not so harsh. There is some individual variation in tone of gray on back and in intensity of cinnamon on flanks aud shoulders, but we are unable to find any correlation in these respects with locality. In other words, we are unable to find any tendency within the range of Ammospermophilus lcucurus in California to form subspecies. The range of the animal is continuous from the Mexican border to the head of Oweus Valley and there are no hindrances to continuous mixing of bieed, such as seem essential to subspecific differentiation in other ground squirrels.

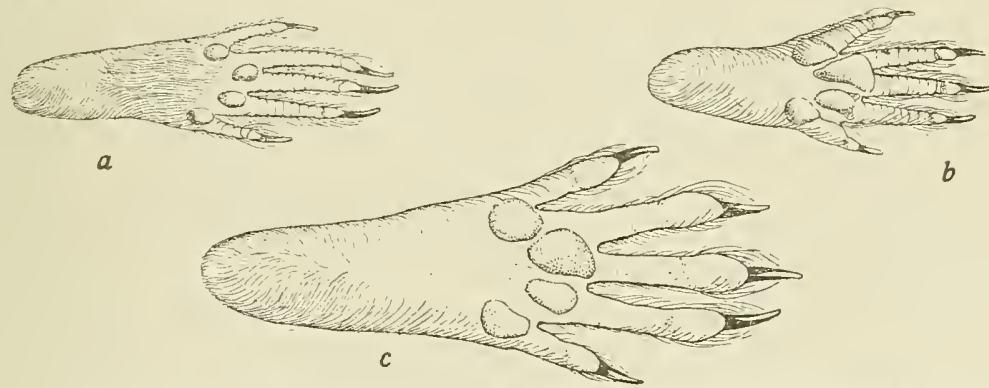

Fig. 26. Feet of ground squirrels to show extent of hairing on soles and position and shape of tubercles, $a$, Desert Antelope Ground Squirrel; $b$, Stephens Soft-haired Ground Squirrel; $c$, California Ground Squirrel. Natural size; drawn from specimens.

The two seasonal coats, winter and summer, are interchanged through a clearly defined procass of molt. That from winter to summer begins as early as April 23 and contiumes in different individuals as late as June 1S; that in the fall extends from September 12 to October 23. These dates are as shown by the specimens available. The spring molt commences on the forehead and proceeds backwards; the last remnants of the winter coat are to be seen on the hind neck and rump. In the fall the order is reversed, and the rump first acquires the new winter pelage, the crown and forehead being the last areas to show the short harsh summer hairs. The hairs of the tail seem to be involved only in the fall molt, in other words they are not replaced in the spring when the rest of the pelage is.

Wear, fading, and contact with alkaline soil bring about some modification in the cones of coloration. In some cases the tails are dirty light brown and the ends of the hairs are all curled up as if scorched by beat. In April specimens from the sanddunes at the edge of Owens Lake near Keeler, the worn winter pelage shorvs a curious yellowish tone, but September examples from the same place, in process of molt, show the new winter pelage to be normal and exactly like that in specimens from Riverside County.

Tre are unable to find any grounds for recognizing a separate race of leucurus from the Inyo region (vinnulus of Elliot, 1903, p. 241, type from Keeler, Inyo County).

Measurements.-Average aud extreme measurements, in millimeters, of twenty adult specimens from Inyo County are as follows: Ten males: total leugth. 21:, (200-235) ; tail rertebræ, $61.5(50-70)$; hind foot, 37.7 (35-40) ; ear from cromn, $5.7(5.0-7.0)$; greatest length of skull, 38.7 (37.5-40.6); zygomatic breadth, 22.3 (21.5-23.1) ; interorbital width, 9.6 (9.4-10.1). Ten females: total length, 211 $(200-220)$; tail rertebræ, 57.7 (46.0-65.0); hind foot, 36.5 (35.0-38.0) ; ear from crown. $5.5(4.0-8.0)$; greatest length of skull, 38.1 (37.1-39.4); zygomatic breadth, 22.1 (20.6-22.9); interorbital width, $9.6(8.9-9.9)$. 
Males seem to be a little larger than females, on an average, with proportionally longer tails. We are unable to find anything in our material to indicate variation in measurements with either altitude or latitude within the state of California.

Weights.-Average and extreme weights, in grams, of twenty adult specimens from Inyo County are as follows: Ten males, 104.4 (94.5-120.7); ten females, 104 (\$3.6-115.0). Average in ounces, for both males and females, about $3 \frac{2}{3}$.

Type locality.-San Gorgonio Pass, below [east of] Banning, Riverside County, California (Merriam, 1889, p. 20; Stephens, 1906, p. 75).

Distribution area.-In general, the southeastern desert region (see fig. 2t). Lifezone chiefly Lower Sonoran, but extends locally up through Upper Sonoran and even into Transition (see fig. 23). More specifically, the Colorado and Mohave Deserts (not, however, in some of the sandier or low-lying parts) from the Mexican line on the western rim of the Imperial Valley and the vicinity of Picacho on the lower Colorado River, north to the extreme head of Owens Valley in the vicinity of Benton, Mono County (Mus. Vert. Zool.).

Along the western edge of the area inhabited by this squirrel, it extends well up onto the sides of the confining mountains and often far throngh the passes, as far as arid conditions prevail ; for example, in San Gorgonio Pass, Riverside County, above Cabezon, and over Walker and Kelso passes, in Kern County, down the valley of the South Fork of the Kern River to as fir at least as Weldon (MIns. Vert. Zool.), thus well orer the rim of the San Joaquin basin. There are in southerm California at least two outlying colonies on the Pacific side of the desert divides; namely, in San Jacinto Valley, Riverside County (Grinnell and Swarth, 1913, p. 326), and in Lytle Creek wash within six miles northwest of San Bernardino, in San Bernardino County (Mus. Vert. Zool.).

Altitudinally, the species ranges from below sea-level, as at Furnace Creek Ranch, -17S feet, in Death Valley, up regularly to 6,000 feet on most of the desert mountains which reach that height, and in some instances to 7,500 feet, as at the north base of Sugarloaf in the San Bernardino Mountains (Grinnell, 1908, p. 141), and even to 8,500 feet, as near the head of Mazourka Canyon, in the Inyo Mountains (Swarth, MS).

Specimens examined.-A total of 271, from the following localities in California. Mono County: Benton, and two miles south of Benton Station, 11. Inyo County: Laws, 6; Silver Canyon, White Mts., 9; Mazourka Canyon, Inyo Mis., 5; Indevencience, and two miles north of Independence, 19; west base Kearsarge Pass, Sieria Nevada, 4; Lone Pine Creek, 4,500 ft., 10; Carroll Creek, 5,500 ft., aud Hockett Trail, 6,500 ft., near Carroll Creek, 4; Keeler, 31; Olancha, 2; Darwin (fifteen miles. and two miles, north of), 7 ; Panamint MIts. (Emigrant, Wild Rose, Hanaupah, and Johnson canyons), 17; Furnace Creek Rancl, and Triangle Spring, in Death Valley, 13; Shoshone, 2; Little Lake, 2. Kern County: Weldon, Onyx, and west slope Walker Pass, 16; one mile east of Warren Station, 1; Mohave, 12. Los Angeleš County : Fairmont, 8. San Bernardino County : one mile northeast of Barstow, 1; Oro Grande, 2 ; mountains on west side of Colorado River, lat. 35 ${ }^{\circ}, 1$; Blythe Junction, 1; five miles below Needles, 1 ; opposite The Needles, 5 ; Chemehuevis Valley, 2; Victorville, 14; San Bernardino Mts. (Cushenbury Springs, Cactus Flat, Doble, north base of Sugarloaf), 17; Cajon (Lytle Creek) Wash near San Bernardino, 1. Riverside County: base of San Jacinto Mts., near Cabezon, 7 ; Snow Creek, near Whitewater, 5; Vallevista, San Jacinto Valley, 4; Palm Springs, 7 ; Carrizo Creek and Dos Palmos Springs, Santa Rosa Mts., 5; Palm Canyon, San Jacinto IIts., 1; Riverside Mt., near Colorado River, 1. San Diego County: San Felipe Valley, 2; Grapevine Spring, 1; La Puerta, 2: Vallecito, 2; Jacumba, 1; Mountain Spring, 1. Imperial County : Colorado River, opposite Cibola, 2: twenty miles north of Picache, 4 ; eight miles east of Picacho, 2.

The Antelope Ground Squirrels constitute a group distinct in many ways from all our other species. They are hardly less inhabitants of the ground, as compared with the tree squirrels and true chipmunks, but in manner they are more vivacious than any of the other ground squirrels; they run at a much faster clip and hence can forage at greater distunces from safety refuges. Their coloration is distinctive, too, gray, with one white stripe along each side of the back, and with the 
under side of the tail brilliantly white. This latter feature is in itself unique, for it is accompanied by a most striking mannerism, that of the almost constant carriage of the stubby, flat-haired tail in an upright position, held against the back, so that the white under surface shows as a white "flag" when the animal is scurrying away, much as with the similarly advertising marks of the cottontail rabbit and antelope; only with the ground squirrel the effect in catching the eye of the observer is still further heightened by the way in which it is spasmodically twitched whether the animal be at rest or running. This flickering beam of white ever holds the attention as long as the squirrel is below the level of the horizon, and short of its burrow or the concealing tangle of prickly vegetation which it is so anxious to put between it and its purstuer.

The race called appropriately Desert Antelope Ground Squirrel (locally, Antelope "Chipmunk" because of its stripes, small size and sprightly manners) occurs broadly over the Colorado and Mohave deserts, thence north clear through the Inyo region. It shows rather wide adaptability to the varying conditions in this vast area, more so than any other desert grome squirrel, and ranges from below sea level, as on the floor of Death Valley, up regularly to 6,500 feet on the steep slopes of the desert mountains. It even "spills over" the confining rim of the Mohave Desert to the westward, locally, on to the Pacific drainage, as shown in detail in the accompanying list of specimens and on the map (fig. 24). Although notably continuous in its range over great stretches of country, it is not difficult to discover preferences, as indicated by relative abundance. Level sandy ground is, as a rule, but sparsely inhabited; and we know of some stretches of desert, such as the floor of the Coachella Valley northwest of Salton Sea, where none at all seem to exist, although the species is abundant in the foothills adjacent. The kind of ground most generally preferred seems to be har'd-surfaced, gravelly wash-fans or hill slopes. Kinds of vegetation present seem to be immaterial, though clumps of squaw tea, creasote bush, cactus, or tree yucca characterize much of the territory where the Antelope Squirrels are most abundant.

Our mention of the above preferences must not give an erroneous idea as to special nature of the habitat of this species. It may be said again, for emphasis, that this animal thrives in a great variety of situations. We have seen it on the mesquite-crowned sand dunes of Death Valley, there as a companion of the Death Valley Round-tailed Ground Squirrel; on the sagebrush covered flats at the extreme head of Owens Valley, in the metropolis of the Stephens Soft-haired Gromnd Squirrel; on the creasote hillsides near Little Lake, one of our very few record stations for the Mohave Ground Squirrel; among the piñons and granite boulders of the northern section of the Panamint Mountains, then associated with the big Fisher Ground Squirrel; and even upon the steep rocky slopes of the White Mountains at 7,800 feet altitude, in the same rock slides with the Inyo Golden-mantled Ground Squirrel! Truly a cosmopolite is the Antelope Ground Squir'el, just so far as the dry atmosphere of the desert extends; but the coastal fog and general hmmidity of the Pacific drainage are almost strictly taboo.

The burrow of this rodent is in nearly all cases situated at the side of a dense brush-chmp nr boulder so that protection is afforded from

r. $4: 3097$ 
predators that dig, such as badg'er's and coyotes. The mouth of the burrow is kept open, and is flush with the surface of the ground; and there is usually no trace of any mound. Sometimes there is a small pile of fresh earth adjacent to a hole, but this is subject to quick dissipation by the winds or the much more infrequent rains. The month of the burrow is subtriangular in outline, the flattish base of the trianglc horizontal at the bottom. It is not often circular, as with pocket gophers and kangaroo rats, and usually can be recognized accordingly. There is evidence that these squirrels use the burrows of other rodents, too, such as those of wood rats, kangaroo rats, and even badgers. And in places where such retreats are afforded, individuals seem to have their headquarters in the interstices of rock slides. Suffice it to say that in the Antelope Ground Squirrel we do not find a good digger. It takes a temperamentally phlegmatic animal to dig effectively. The "Ammos" are too fidgety.

This species does not live in colonies in the restricted sense in which this term should be used, but the burrows are scattered ont pretty evenly over the general territory occupied. There is less of interdependence between the individuals of this species than in most other ground squirrels.

In traveling throngh their domain one secs ferv of these ground squirrels as compared with their real numbers. They are adepts at dodging behind bushes, and at ehuding observation by skipping off out of sight considerably in advance of the intruder. For example, in a census of animal life taken near Nohave, March 1t, 1918, during a three-hour walk, but two Antelope Squirrels were seen, whereas six were found to have been canght in a line of rat-traps dning the same length of time. Then, too, the characteristic tracks in the sand on a quiet day after it has been laid by a norther leave a graphic record of the multitudinous peregrinations of these active rodents. They can make more tracks in a given length of time than any other mammal with which we are acquainted!

Some notes made by the senior author the second week of March, 1918, near Mohave will help to give a clear idea of the characteristics of the animal under discussion. Nearly all individuals seen would run very fast across open spaces between the bushes, but would hesitate a moment or so when passing through the bushes. When approaching its burrow each animal would stop stock still just short of the mouth of the burrow, and watch the intruder intently with head turned to one side sufficiently so that it could look back past its rump. Meanwhile the tail was vibrated intermittently as usual. Presently the animal would dive down out of sight. One was seen to go down into a hole situated in the side of a mound of sand accumulated about the base of a very large creasote bush. This hole was one yard from the nearest upright stem, but was directed downward diagonally toward the rootsystem, and it was overshadowed by the radiating branches. The diameter of this burrow at its mouth was just 40 millimeters (about one and three-fifths inches). The last that was seen of another squirrel as he dived for his burrow, he had his tail over his back twitching as violently as ever. He, too, had hesitated just an instant before the final plunge. 
One individual was surprised eight feet above the ground in a troe yucea, where he had doubtless been prospecting among the ripe pods for the seeds. He ran cown the yucea trunk head foremost, with clearly audible noise of claws on rough bark. Fven in this position the tail was kept appressed to the rump and was flicked in fore-and-aft direction. This ability to climb is not exceptional among individuals of this species, and is quite consistent with the general agility of the animal. Near Keeler, on the morning of September 25, 1917, six individuals were seen severally in the tops of sarcobatus bushes evidently gathering the small, fleshy leaves. At the distant approach of the observer each scurried to the ground and each had altogether disappeared by the time he had come up. At Onyx, Kern County, June 21, 1911, one was seen perched on the top of a fencepost. At Carroll Creek, near Owens Lake, September 8, 1911, several were seen at different times perched bolt upright, picket-pin fashion, on isolated boulders out on the mesa.

As a general thing Antelope Ground Squirrels do not have access to water and they live for long periods without it. Like other typically desert rodents, they can secure all the water needed in their systems by chemical elaboration of their food materials. Yet that water is sought for where available is shown by the following instances: When camped at a spring near the head of Kelso Valley, Kern County, July 8, 1911, the senior author saw an "Ammo" come without hesitation to the lowest hoofprints containing water below the spring and drink five times; each time about ten seconds were apparently occupied in lapping. At intervals the animal looked around, vibrating his tail the while with great rapidity. At least six other individuals came to drink during that day, arriving through the brush from considerable distances. One of these, observed closely, was seen to lap hurriedly and briefly eight times.

Some observations made at the same time and place bear further on the behavior of this species of ground squirrel. When one is stalked it will make a dash of ten feet or more to a near-by shrub or rock. If the observer continues to advance the squirrel disappears down a hole or under a bush, or else makes another similar dash and stops again. It then either stands on all fours with its back humped up toward the intruder and its head turned around so as to watch, or it stands upright on its haunches, turning more toward the observer. In either case the tail is held over the back and is wiggled, either anteroposteriorly or laterally. The tip of the tail, at least, shows no constant direction of movement. "When entering a burrow I saw one individual drop his tail down behind him and trail it into the burrow instead of carrying it over his back" (Storer, MS). Often when running an "Ammo" will be seen to jump short distances, quite clearing the ground. "I saw one in a tree yucea where I only came to detect his presence by seeing the shadow of his wiggling tail" (Storer, MS). The animals seem to be able to climb the prickly cactuses and yuccas without sustaining any serious injury.

The voice of the Antelope Squirrel is unique among the members of its tribe. It is not a "bark" at all; nor is it a "squeak." It may be described as a prolonged mellow rolling trill, weakening or falling in inflection toward the end. The tone is maintained on about the same moderately high pitch throughout, though an impression of lowering 
may be received because of the progressive diminution in volume. The sound is of a quality to carry well, yet even at very close range it rarely sounds loud. The direction of the performer is usually hard to fix. This shifting, ventriloquistic quality goes well with the shimmering landscape and elusive behavior of the animal, with which it is usually associated in our experience.

The breeding season begins about the first of March and, in its various phases, lasts ordinarily until the end of May. At the highest altitudes the program is evidently retarded some because of the later advent of warm weather. There is nothing to indicate that more than one litter is produced each year by one female. The instances of late appearance of young (for example, in August), where not accounted for by altitude, would seem likely to be due to individual variation in time of development of the reproductive instincts or else to abortion or early death of the first litter. The following is the more or less exact breeding data given in the field notes on file in the Museum of Vertebrate Zoology.

The earliest date for embryos is February 20 (1910) near Needles on the Colorado River; the number of embryos was eight. On March 11 (of the same year), in Chemehuevis Valley, south of Needles, a female was taken containing five embryos. The weather was yet cold, ice on standing water at night. It seems to be a rule with the squirrel family in the desert that the breeding season is so timed that the young of the yeal are well grown long before the period of intensest summer heat.

March 11 to 16 (1918) thirty Antelope Squirrels were trapped or shot in the vicinity of Mohave. Of these, seventeen were males and thirteen were females, all adult and in breeding condition. The testes of the males were huge, measuring up to three-fourths of an inch in length. The uteri of the females were heavy-walled, but in only one case. were there yet any embryos; one taken March 11 contained five well-developed embryos. The males were lean; the females all more or less fat. On March 18 (1914) at Victorville two females were taken. containing thirteen and fourteen embryos, respectively. On March 27 (1907), at the same place, a female was found to contain eight embryos. On April 6 (1918), at Olancha, two females contained nine and ten embryos, respectively; and on April 12 one was found to contain seven embryos. On April 24 (1912) at Keeler a fenale was taken which contained six embryos.

The average number of young per litter as figured from the above records of embryos is close to nine, with five and fourteen as extremes. Stephens (1906, p. 75) considers five to eight as the usual number. Nelson (1918, p. 443) gives four to twelve. Mearns (1907, p. 301) records that near Mountain Spring, in May, 1894, ten small young of uniform size were caught from one hole.

The mammæ are generally in five pairs, occasionally in six, rarely five on one side and six on the other.

The earliest date we have for the appearance of young aboveground is April 23 (1917) at Furnace Creek Ranch, Death Valley; one youngster scarcely one-fifth grown (its weight was but 17.7 grams) was found wandering about weakly under a mesquite (see fig. 27). The next date is May 13 (1908) for third-grown young at Cabezon, and records for 
the last week of May are numerous. The latest date is September 4 (1908) for half-grown young at Vallevista, San Jacinto Valley. From all the facts at hand we would estimate the usual date of birth for this species to be close to May 10.

By the time they are half grown the young seem to be well able to forage for food by themselves. No solicitude has been observed on the part of the parent. The young show themselves to be less shy than adults, and for this reason it is probable that a large toll is taken by their enemies during early summer, until the young get sophisticated.

The Antelope Ground Squirrel, according to the data above given, is the most prolific of all our species of ground squirrels. It can be inferved from this that existence on the desert, in the mode followed

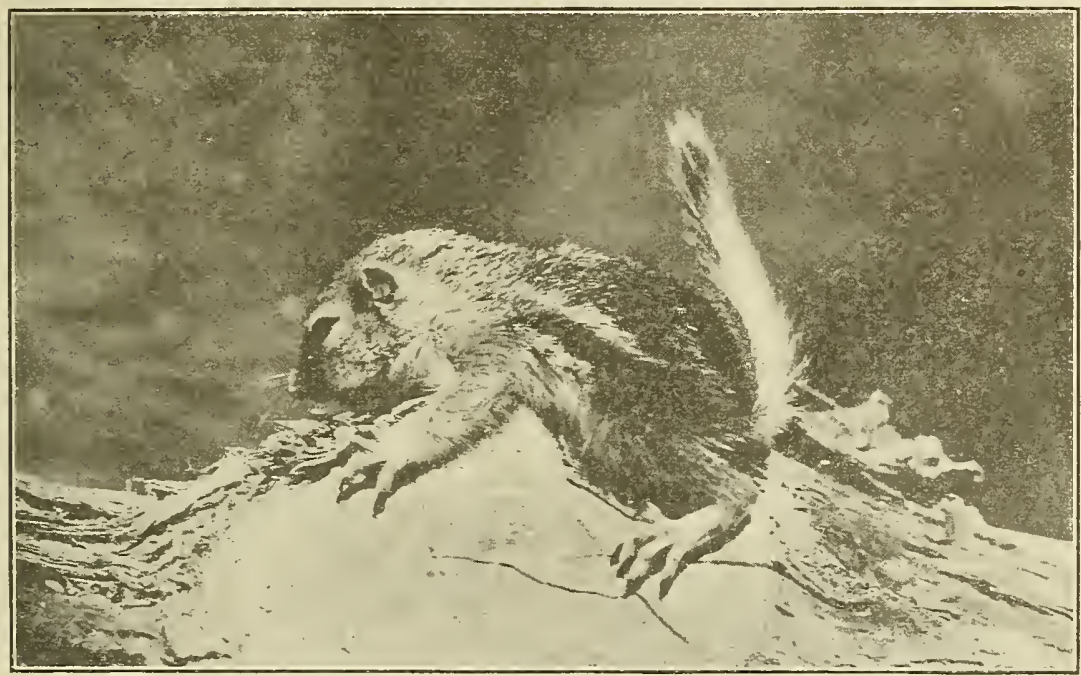

FIG. 27. Desert Antelope Ground Squirrel, about one-fifth grown, found wandering about weakly under a mesquite at Furnace Creek Ranch in Death Valley, April 23, 1917. Photographed by J. Dixon. Although very young and feeble this little squirrel persisted in holding its tail at all times ovel its back in characteristic Ammospermophilus fashion.

by this squirrel, is the most precarious. The factor of high mortality must therefore be provided against by high birth rate. The category of predaceous animals which occupy the same territory and which are sure to prey habitually upon the Antelope Squirrel includes "snakes, weasels, foxes, coyotes, badgers, bobcats, and many kinds of hawks" (Nelson, 1918, p. 443).

At all the lower elevations, where the winters are not especially cold, Antelope Ground Squirrels are to be seen abroad at all seasons. For instance, around Victorville in December and January, 1904-05, and at Palm Springs in December, 1904, they were to be seen nearly every day, though they did not seem to be foraging far and wide actively then as is their wont in March and later. At the former locality on the coldest windy days none was seen. It is very likely that at higher places, altitudinally, especially where there is some snow, as at the head of Owens Valley, these animals hibernate through the coldest months. 
The fact that there is a special winter pelage, long, full and silky, would seem to have some meaning as an accompaniment of outdoor activity at that season. Certain it is, that in texture, the pelage of the Antelope Squirrels is quite different from that of those species which hibernate regularly and long. The latter are woolly, with much under-fur. In the fall and winter "Ammos" are uniformly very fat. This condition is probably maintained by drawing upon their food stores, which, to judge from their persistent industry earlier in the season, must be extensive. We have never taken the opportunity to dig out the burrows to see how the seeds and other foodstuffs are garnered. Interesting facts doubtless await inquiry in this direction.

The Antelope Ground Squirrel is preëminently a gatherer of seeds and fruits. The two inside-opening cheek-pouches are extensive, doubtless on this account. Rarely does an animal captured away from its burrow fail to show something in them. The following records of findings of this nature will give a good idea of the diet of the species:

In the tree-yucea belt near Mohave, March 11 to 16, 1918, many of the squirrels examined were carrying the large flat black seeds of the tree-yucca (Yucia brevifolia). These seeds were being gathered for the most part from the ground, where they had fallen from the podclusters overhead. But in a few cases the squirrels were seen up in the yuccas going right after the ripe pods themselves. The greatest number of these seeds being carried at one time was seventeen, this in the case of a male taken on Lee Flat, fifteen miles north of Darwin, September 28, 1917. A female taken in Walker Pass, June 27, 1911, contained in its cheek-pouches 98 shelled seeds of juniper (Juniperus californicus). A female captured at Keeler, April 28, 1912, had gathered into her cheek-pouches 178 husked seeds of the salt-grass (Distichlis spicata).

Cactus seeds are frequently gathered, and, in season, the fleshy fruits are eaten. At Vallevista, San Jacinto Valley, September 4, 1908, the squirrels were feeding chiefly on the ripe cactus "pears." The animals were well stained with the purple juice both outside and in; the whole abdominal region was purple in some of the individuals skinned for specimens. At Cabezon, May 6, 1908, a squirrel was watched in the top of a cholla cactus eating the tender new-growth buds. The animal seemed to be able to move about without its feet being injured by the spines, but upon being shot a thorn was found sticking firmly in the roof of its mouth.

This squirrel also gathers, doubtless for food, the stems of squaw-tea (Ephedra), cut into sections, and the leaves of Sarcobatus. Immediately after rains, when the evanescent annual vegetation of the desert starts to grow, sprouting plants of certain species are also gathered.

Judging from the frequency with which Antelope Ground Squirrels get into meat-baited traps, they must have a decided taste for flesh. We have also frequently found them eating into the bodies of rodents already caught and killed in small traps, and in one case, at least, one of its own kind was the victim. Nelson $(1918$, p. 443) says that insects are eaten when occasion offers.

As for cultivated crops, it is not often that Antelope Ground Squirrels are to be found in settled regions, and even where they are, they do not seem to be attracted by the conditions which accompany irrigation. For example, around Cabezon in San Gorgonio Pass, in May, 1908, the 
farmers and orchardists reported that little or no damage was done by this rodent, although the big Fisher Ground Squirrel was a decided pest there. The little Antelope "Chipmunks" seemed to keep closely to the wild land, feeding upon the native seeds and fruits, especially those of the cactuses.

Still, locally, they may prove noticeably destructive. This was the case in an almond orchard near Fairmont in northern Los Angeles County, where in June, 1904, the present authors saw the animals climbing the trees in the outer rows next to the wild land and carrying down the as yet unripe almonds. These and the Fisher Ground Squirrels were both complained of bitterly by the owner. Again, in Owens Valley near Independence, on May 7, 1912, a male Antelope Ground Squirrel was captured, with its cheek-ponches filled with wheat. The nearest grain field was a quarter of a mile distant. It is thus quite to be expected that where cultivated land adjoins wild land this species will make raids upon such crops as prove to its liking.

\section{NELSON ANTELOPE GROUND SQUIRREL.}

\section{Ammospermophilus nelsoni nelsoni (Merriam).}

Other names.-Nelson Spermophile; Nelson Ground Squirrel; Antelope Chipmunk, part; Spermophilus nelsoni; Citcllus nelsoni.

Field characters. - A small yellowish-brown ground squirrel with one narrow white stripe on each side of body, and with a short flat tail nearly always held curled up over the rump so as to show the creamy white under side. Length of body alone about $6 \frac{1}{4}$ inches, tail about $2 \frac{4}{5}$ aches more.

Description.-Adult in summer pelage: General color of upper surface from nose to base of ta'l light clay color, brightening toward pinkish cinnamon on shoulders, flanks, and outer sides of fore and hind limbs; a narrow white stripe on each side of body from shoulder to side of rump. Eyelids, ears and sides of head dull buffy white; whiskers black. Whole lower surface of body white, the hairs white to bases; soles of feet densely white-haired forward to tubercles, thence to balls of toes naked; upper surfaces of feet white, buff tinged; claws blackish brown with pale hor'n-colored tips. 'Tail as in leucurus, but upper side near base clay color; under sulface creamy or bufiy white centrally. Adult in winter pelage: Coat softer, the hairs being longer and more silky than in summer. General coloration as in summer, but tome of upper surface a little darker, and with a fine grizzling due to more variegated color pattern on the individual hairs. White hairs of lower surface with extreme bases lead-color.

Color variations.- Sexes alike, as far as we can see. Young colored as in the summer adults, but pelage finer in texture.

Measurements.-Average and extreme measurements, in millimeters, of twenty full-grown specimens from the vicinity of Bakersfield, Kern County, are as follows: Ten males: total length, $226(210-2+2)$; tail vertehræ, $70(61-76)$; h'nd foot, 38.6 (36-40) ; ear from crown, 5.3 (5-6) ; greatest length of skull, 39.9 (39.0-41.6) ; zygomatic breadth, $23.2(21.4-25.0)$; interorbital width, 9.9. (9.5-10.4). Ten females: total length, 221 (203-23S); tail vertebræ, GS (64-74); hind foot, 3S.4 $(35.0-41.0)$; ear from crown, $5.7(5.0-6.0)$; greatest length of skull, 39.4 (37.8$41.3)$; zygomatic breadth, 22.6 (21.5-24.4) ; interorbital width, 9.7 (9.0-10.6).

Males will be seen from the above figures to arerage slightly larger than females. The decidedly greater size of nelsoni as compared with leucurus is at once apparent.

Weights.-Three adult females were found to weigh 141.S, 142.6, and 179.0 grams, respectively; average, 154.5 grams, or $5 \frac{1}{2}$ ounces. In bulk nelsoni is thus about 50 per cent larger than leucurus. 
Type locality.-Tipton, Tulare County, California (Merriam, 1S93, p. 129).

Distribution.-Occupies the floor of the southern end of the San Joaqnin Valley, and adjacent arid hills and included valleys immediately to the westward (see fig. 24). Life-zone Lower Sonoran. More specifically, extends from vicinity of Bakersfield ( $S$ miles northeast) and Poso, in central Kern County, west to the Carrizo Plains and Cuyama Valley, in southeastern Sau Luis Obispo County, south to the mouth of San Emigdio Creek, 12 miles dne east of Maricopa, Kern County, and north to Huron, Fresno County, and Tipton, Tulare County.

Specimens examined.-A total of 43 , from the following localities in California. Kern County: eight miles northeast of Bakersfieln, 32; twelve miles due east of Maricopa, 5; McKittrick, 3. San Luis Obispo County : Carrizo Plains, 3.

The Nelson Antelope Ground Squirrel is called Antelope Chipmunk by many of the people who live in the southern San Joaquin Valley. No distinction is made by them between the present species and the Antelope Squirrel of the Mohave and Colorado deserts. This is not surprising when we consider the rather close general resemblance between the two. When specimens of the two animals are in hand, tone of coloration alone suffices for distinguishing them. The ground color of the Nelson Squirrel is distinctly elay color, while that of the Desert Antelope Ground Squirrel is pinkish buff. In the former, too, the under side of the tail is creamy buff, while in the latter it is pure white. In bulk the Nelson is approximately 50 per cent the larger.

The Tehaehapi Mountains on the south and the Greenhorn Mountains to the east help to form a continuons barrier between the range of these two near-related squirrels. We find the Nelson Squirrel to be restricted for the most part to the Lower Sonoran life-zone in that portion of the San Joaquin Valley which lies south of Tulare Lake. It is notably numerous in the oil distriets. The Nelson Squirrel may be distinguished from all other rodents that oceur in this region by having a very short, flat-haired tail (less than 3 inches in length) and by the presence of a single white stripe on each side of the body. The name borne by this speeies was given to it by its original describer (Merriam, 1893, p. 129) as a recognition of the contributions to mammalogy of Edward W. Nelson, now chief of the United States Burean of Biological Survey.

During the rainy season many of the smaller streams in the southern and western foothills around the San Joaquin Valley eut deep and narrow channels, but when the flood waters of such streams reach the upper plains of the great valley their course is marked by broad washes with low, perpendicular banlss. The silt-bearing waters finally spread out, forming broad, alluvial fans, and often sink into the thirsty soil before they reach the lower alkaline plains. The lower reaches of such stream courses, dry and desertlike most of the year, are the preferred haunts of the Nelson Ground Squirrel. Here burrows are easily dug between the hard layers of the stratified banks of the washes, affording safe retreats from such predators as the coyote and badger. A luxurious though brief-lived growth of vegetation results from the thorough natural irrigation of the rich soil of the alluvial fans and the squirrels are thus afforded an abundant food supply the rest of the year. Individuals and even colonies are to be found along the little gullies and ridges of the upper slopes between the months of the streams and the foothills, while a few may be found along the edges of the allkali ground 
of the lower levels; but the metropolis of the species is in the middle region among the salt-bushes (Atriplex) which thickly dot these plains.

This ground squirrel is soon driven out when fields come under cultivation. It clings closely to the wild land and apparently rarely if ever invades adjoining ground. which may happen to be under eultivation. Thus in May, 1918, at the mouth of San Emigdio Creek, Kern County, we found these squirrels quite abundant on three sides of an extensive alfalfa field which was entirely surrounded by virgin tracts of the salt-bush (Atriplex), yet during our stay of nearly two weeks, not a single Nelson Squirrel was observed to enter this field or even to touch a leaf of the alfalfa.

As usually encountered, the Nelson Squirrels are seen scurrying rapidly across open places between clumps of salt-bushes, or else, more rarely, standing straight up to their full height in true "picket-pin" fashion just before they disappear down their burrows. The normal mode of travel is by a series of short rapid jumps of from 6 to 12 inches. When approaching a hole leisurely, or when foraging about, the animals sometimes slow down into a walk.

These squirrels are not early risers, being rarely found abroad until well after sun-up. At the mouth of San Emigdio Creek, during the second week in May, Nelson Squirrels began to appear at the entrances to their burrows in the south-facing overhanging bank of a wash, between 8 and $8: 15$ in the morning. They appeared earlier in the day at this point than elsewhere in the vicinity, doubtless because this bank first received the full force of the early morning sun. Ten o'clock marked the period of greatest activity. The squirrels under observation disappeared each day between 11:30 and 12 o'clock and were rarely seen again until $2: 30$ in the afternoon, when they began to reappear in the shade of certain dense-foliaged salt-bushes that grew on the brink of the wash. Although they were frequently seen to bask in the rays of the early morning sunshine, these squirrels shunned the direct sunlight at noonday. As early even as 10 o'clock in the morning one female was seen repeatedly to seek shelter in the shade of a fencepost ( $J$. Dixon, MIS).

The tail of the Nelson Antelope Squirrel, as with the Desert Antelope Squirrel, is the most conspicuous feature about the animal. When running, the tail is curved forward over the back, in which position the creamy under surface is most effectively displayed so that at a distance one receives the impression that merely a bit of thistledown is blowing along over the sand. The body of the animal, with its ground-like tone of color, practically disappears. This illusion is furthered by the twitching of the tail and by the momentary pauses of the animal which correspond closely with the usual interrupted flight of a tuft of tristledown.

When the squirrel is foraging about on all four legs, or else sitting up, the tail is held curved forward over the back; in fact, one rarely sees the tail held in any other position (see fig. 28). At such times the tip of the tail is often curved slightly upward or outward. When excited or frightened the tail of the animal is twitched rapidly fore and aft, but rarely or never sideways. One individual observed at a distance of ten feet was seen to vibrate its tail intermittently with exceeding rapidity, there being half-minute intervals between the periods of 
vibration. There were from four to six of these periods of vibration in a series. The tip of the tail would travel only a short distance, less than a couple of inches, as it was never seen to reach a vertical position above the animal's back when the squirrel was standing on all fours.

These squirrels are notably cautious about coming out of their holes; they were never seen to come out hastily. First the nose and then the eye of an animal would stealthily appear, and then a thorough look around for possible danger taken, before a squirrel considered it safe to leave the shelter of its burrow. However, when they do move, their actions are very sudden, as though they had been undecided just what to do, but having once made up their minds are off in a whirl of dust. These rodents are more easily alarmed by sound than by sight. The

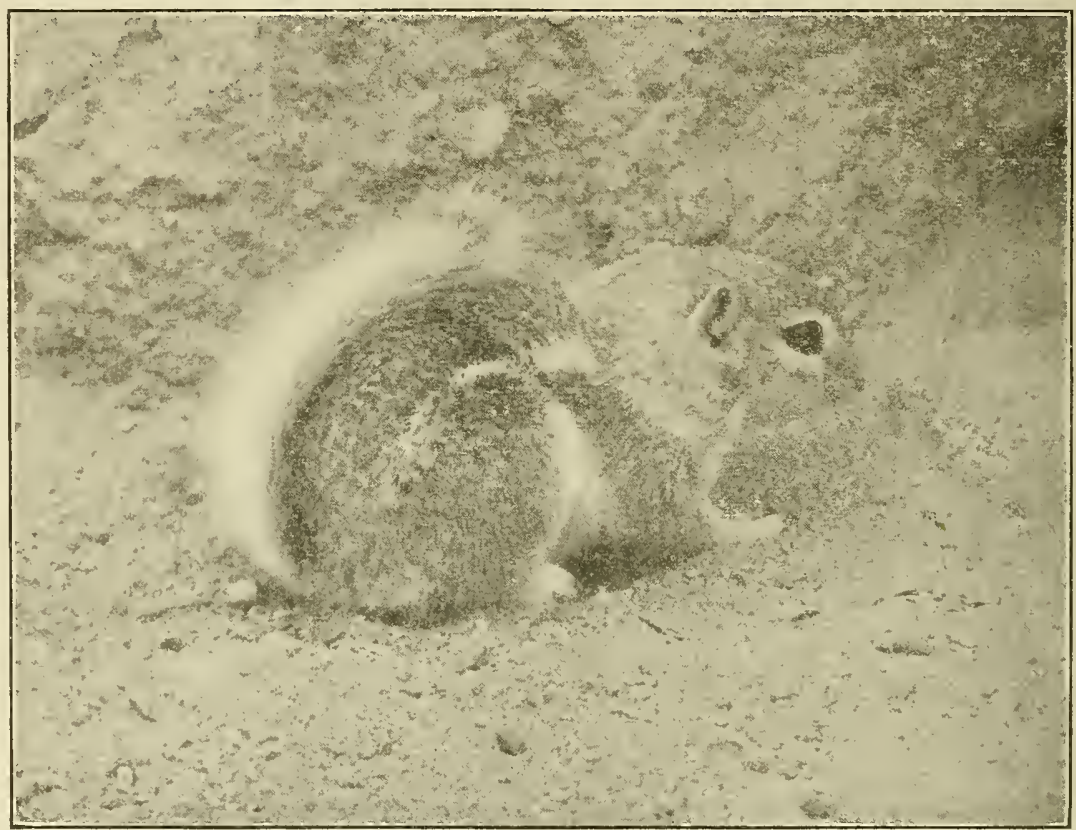

FIG. 28. Young Nelson Antelope Ground Squirrel, photographed by J. Dixon, May 9. 1918, on lower San Emigdio Creek, Kern County. Note how well the general color of the animal blends with the tone of the background, and yet how strikingly the white of the under side of the tail shines forth.

cracking of a twig would send them hot-footed to their burrows. Yet the observer was able to walk up to within thirty feet of them in plain sight in the open as long as he made no violent motions. By approaching slowly and directly towards the squirrels, it was frequently possible to get within ten feet when they were sunning themselves at the entrances to the burrows under the overhanging banks.

The sense of smell seems to be extensively used in the daily life of these animals. At the elose approach of the observer the noses of these little squirrels were seen to twitch constantly as if in effort to catch the scent of the stranger. The sense of smell also plays an important part in locating food. Then again it is used socially. When following each other about, in and out of the burrows, they often stop and sniff to see 
which way the other has gone. Smell serves as a means of identifying the other members of the same family. Outsiders are quickly detected and promptly driven away. The members of one family of squirrels which was closely watched were found to be very sociable, never quarreling among themselves. The parents were often seen sitting side by side feeding in perfect harmony (see fig. 29), while at other times this pair would sit together and rub noses in a very affectionate way. The only time that they were seen to show fight was when a strange male squirrel attempted to enter their burrow, and then the male of the pair promptly put the intruder to flight.

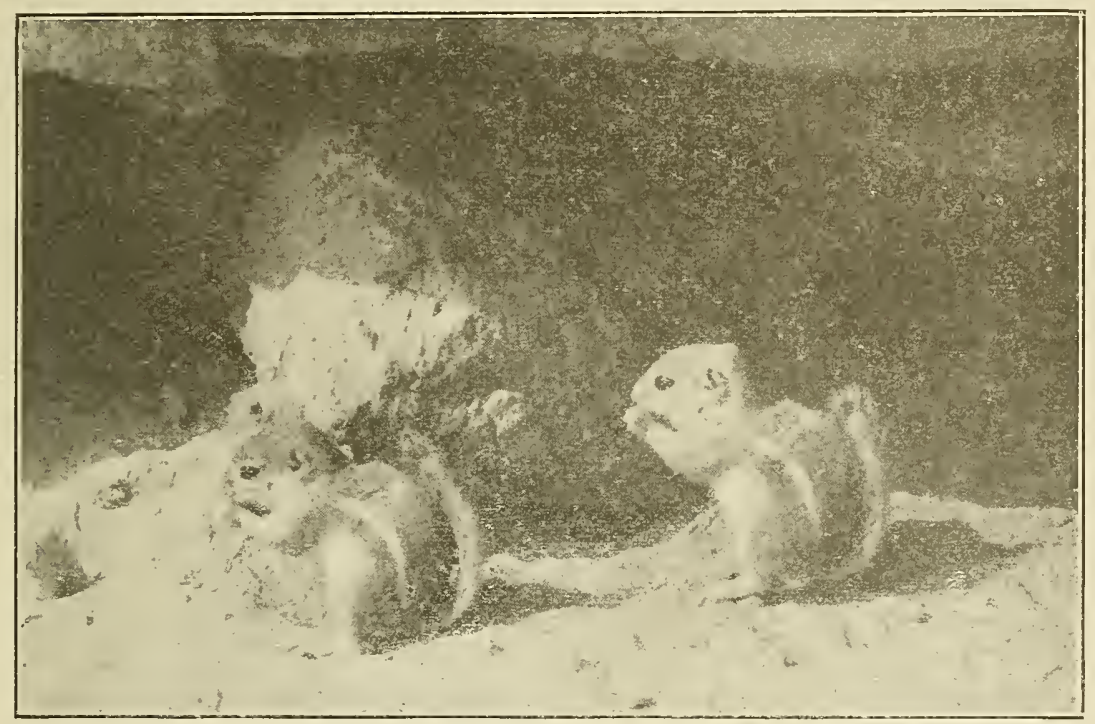

Fig. 29. Adult male and female Nelson Antelope Ground Squirrels, feeding in narmony side by side under wholly natural conditions. Photographed by J. Dixon, May 9, 1918, on lower San Emigdio Creek, Kern County. The openings under the horizontal layers of the wash banks afforded these squirrels safe retreats. Note the characteristic Ammospermophilus pose of body and tail.

The alarm note of the Nelson Antelope Ground Squirrel is much subdued as compared with the clear penetrating trill of the Desert Antelope Ground Squirrel. In fact, the former is much less frequently heard at all. While the junior author was watching a family of Nelson Squirrels at play on the morning of May 8, 1918, an old female was seen to disappear into one of the numerous holes in the bank. About two minutes later his attention was attracted by the low, inquisitive chirr of this same squirrel, which was standing motionless less than ten feet behind him. This alarm note was repeated five or six times at intervals of from 30 to 45 seconds. In uttering this note the mouth was opened, but the effort was not convulsive nor was the thorax greatly contracted. The note was subdued in tone and probably not audible to human ears at a distance exceeding one hundred feet. The confidential quality of the call note reminded the observer very much of the clurcking note of the female valley quail when keeping her young together. 
Numerous holes in the sides of gullies and in the banks of washes form the most conspicuous signs of the presence of the Nelson Squirrel. Tracks and mounds at the entrances to burrows are not as noticeable as one would expect from the number and size of the animals. Trails from the burrows to the feeding grounds of this species are usually not well defined. In one place near the mouth of San Emigdio Creek these squirrels were obliged to cross a large dusty area in traveling back and forth between their burrows and their feeding grounds. Numerous tracks in this dusty spot showed that the squirrels in this colony did not follow definite trails, but that each individual chose his own route. In passing around a projecting bank, however, the tracks were found to converge for a short distance into broad, well-beaten paths six to eight inches wide.

The favorite location for burrows of this squirrel is, as already stated, in the sides of banks at the edges of washes or gullies. The burrows usually enter near the bottom of the bank. The entrances to the burrows vary from $1 \frac{1}{2}$ to 8 inches in diameter. The largest holes are in soft ground beneath horizontal hard strata in the bank and their large diameter is due at least in part to the weathering or caving in of the soft earth. The burrows of smallest diameter are found in hard, level ground at the roots of Atriplex bushes. The entrances to burrows in the banks are from six inches to fifty feet apart. These bank burrows run back in a generally horizontal direction and are interconnected to a considerable extent under the bank. This was proven by sceing a certain squirrel, known by sight to the observer, disappear into one hole and then in a few minutes reappear at the mouth of an adjoining burrow twenty or more feet distant.

All of the eight burrows dug into by various persons from this museum have proven to be simply refuge burrows, with only one entrance; that is, not of the intercommunicating type. Squirrels were found to reappear in from 5 to 15 minutes after they were chased into such burrows. These refuge burrows were found to be short, less than twelve feet in length; shallow, less than three feet in depth; and of small size, less than two inches in diameter. In three cases the squirrels were gassed in these burrows and an hour later dug out. Two of the animals were found dead near the wasteball at the entrance of the burrow, where they had evidently been overcome by the gas when attempting to make their way out.

No nests were found in any of the burrows that were dug out, although nesting burrows were particularly sought for. Consequently we have no information to offer regarding this phase of the animal's life history.

The Nelson Squirrels found near the mouth of San Emigdio Creek were found to be moderately infested with fleas. The squirrels were often seen to stretch out to their full length and roll over and wallow about in the fine powdery alkaline dust which in many places was an inch deep under the overhanging banks along the edges of the washes. Such dust baths, which were frequently indulged in with considerable evident satisfaction by the squirrels, are likely to serve in keeping the pelage of the animal clean as well as to discourage the fleas.

Our data regarding the breeding of Ammospermophilus nelsoni is scanty. The brceding season appears to be much earlier in this species than in the case of the Fisher Ground Squirrel in the same region. 
The young of nelsoni are apparently all born before the last of April. None of the numerous females taken in the vicinity of Bakersfield between April 27 and May 12 were found to contain embryos. A male one-fourth gromn was taken eight miles northeast of Bakersfield on May 7, 1911, and a half-grown young one was taken at MeKittrick on May 18, 1911. On May 9, 1918, two immature individuals, weighing 100 and 103.3 grams, respectively, were taken at the mouth of San Emigdio Creek. These, male and female, were thus over two-thirds grown and were at this time foraging for themselves. These two youngsters were extremely playful and on several occasions they were seen to stand upon their hind legs and with their front paws braced against one another's shoulders they wrestled and pushed each other about energetically. 'The parents of these young' squirrels had evidently cast them off to shift for themselves.

Because the California and Fisher Ground Squirrels have-increased and profited by the farming activities of man in parts of the San Joaquin Valley, it has been suggested that possibly this increase has tended to crowd out Ammospermophilus nelsoni and therefore restrict the range of the latter (Taylor, 1916, p. 20). At the mouth of San Emigdio Creek both nelsoni and fisheri were found in numbers. Old colonies of fisheri, as shown by their extensive workings, were found between colonies of nelsoni. The Antelope Squirrels occupied the sandy washes and the areas covered by the salt-bush, while the Digger Squirrels occupied the more open tracts which were covered by a low growth of foxtail. While there must be a certain degree of competition as regards food supply between the two kinds of squirrels, this competition is probably no greater than that which exists between the Nelson Antelope Ground Squirrel and, for example, each of the two species of kangaroo rats which forage at night for similar food over the same ground used by the Nelson Squirrels in the daytime. We found no evidence, in this case, that the Digger Squirrels were driving out the Antelope Squirrels.

The badger is one of the chief enemies of the Nelson Ground Squirrel. Many squirrel burrows were found that had been dug out by this animal, and, since in their refuge burrows these squirrels have no back door of escape, capture in such cases must be more or less certain.

On May 19, 1918, a pair of Nelson Squirrels was observed to remain out in the open and watch a pail of Golden Eagles go through a series of aerial evolutions overhead, in which, with talons tightly locked together, the birds looped the loop three times. The eagles were obviously seen by the squirrels, and the swish of their wings was plainly heard by the observer, yet the squirrels were not in the least alarmed. However, when a Red-tailed Hawk flew over, the squirrels hustled at once into their holes. It was therefore inferred that the hawks and not the eagles were the active enemies of these small squirrels. Coyotes and kit foxes also dig out the squirrels in their burrows and probably pounce upon a few individuals during the daytime.

In foraging, these squirrels slip along close to the ground, often stopping in the sheltel of a bush or pausing in the open and searching quietly, with body extended, for small seeds upon which they feed. On May 6, 1918, an old female which was nursing young was observed for several minutes at a distance of fifty feet. During this time the squirrel stood at her full height with body erect, busily munching a green head 
of alfilaria and keeping a careful watch at the same time upon the intruder. A few days later a squirrel of this species was seen gathering dry seeds of the alfilaria. It is difficult in the field to be sure just what kind of seeds the squirrels are seeking out, since the seeds are too small to be seen at any great distance even with the aid of binoculars, and the stomach contents are so finely chewed that it is impracticable to identify the food constituents.

On one occasion an individual was seen to eat the dried flesh from the hind leg of a dead kangaroo rat. This sort of provender had been secured from a near-by meat-baited steel trap. From this incident we conclude that this species of squirrel is not altogether vegetarian in its food preferences.

Very little information is at hand regarding the food carried in the cheek-pouches of this rodent. A specimen taken at McKittrick, Kern Comnty, on May 19, 1911, had 744 seeds of the alfilaria (Erodium cicutarium) in its cheek-pouches. No food stores of any kind were found in the few burrows excavated.

The Nelson Antelope Squirrel is distributed unevenly. It occurs in abundance at only a few localities. At one of these favored localities, eight miles northeast of Bakersfield, squirrels of this species were found scattered over the low hills in little colonies of six or eight individuals (H. S. Swarth, MS). It is believed that there were certain small areas here that supported at least twenty-five of the squirrels to the acre. However, they were present to this extent on only a small per cent of the total acreage inhabited. At San Emigdio 'Ranch ten squirrels represent the greatest number found on any one acre. At McKittrick the number per acre was thought to be not over five. Taking the entire range of the species into consideration, there is probably about one squirrel to every two acres.

Our impression is that on the east side of the San Joaquin Valley the range of this squirrel is now being rapidly restricted by farming activities. In 1911, and again in 1918, no Antelope Squirrels whatever could be found in the vicinity of the type locality, Tipton, in Tulare County, where it was common in June, 1893 (Merriam, 1893, p. 129). The first Nelson Squirrel was noted in the 1911 search thirty miles south of Tipton. The gradual settling up of the country, and the cultivation of the kind of ground inhabited by this squirrel, has resulted in the crowding out of the species over much of the eastern part of its original range. It seems only a question of time when continued reclamation will gradually restrict and eventually exterminate this species over the arable portions of the San Joaquin Valley.

The Nelson Antelope Ground Squirrel is at the present time of little or no economic importance. It inhabits barren situations, apart from cultivated land. Our opinion is that this squirrel is not likely ever to become a pest.

\section{LOS BAÑOS ANTELOPE GROUND SQUIRREL.}

\section{Ammospermophilus nelsoni amplus Taylor.}

Other names.-Nelson Ground Squirrel, part; Antelope Chipmunk, part; Ammospermophilus nelsoni, part. 
Field characters.-Exactly the same as for the Nelson Antelope Ground Squirrel.

Description.-General coloration in all pelages exactly as in melsoni proper, but clay color of upper surface a trifle paler, more buffy, and white side-stripes less distinct. Size somewhat greater, especially as regards ears.

Measurements.-Average and extreme measurements, in millimeters, of twenty full-grown specimens from twenty miles south of Los Baños, in westeru Fresno County, are as follows: Ten males: total length, 246 (234-253) ; tail vertebræ, 73 $(66-75)$; hind foot, $41(40-43)$; ear from crown, 7.8 (7.0-9.0) ; greatest length of skull, 41.8 (41.0-42.7) ; zygomatic breadth, 24.8 (24.0-26.2); interorbital width, 10.1 (9.4-10.4). Ten females: total length, 236 (230-243); tail vertebræ, 73 (67-78); hind foot, 40 (37-43) ; ear from crown, 7.7 (6.5-9.0); greatest length of skull, 41.2 (39.8-42.0) ; zygomatic breadth, 24.3 (23.5-25.5) ; interorbital width, 10.0 $(9.2-10.3)$.

Comparison with the measurements given for nelsoni will show that amplus is decidedly larger, with especially larger ear.

Weight.-Only one record of adnlt weight is available, that of an old male, 186.3 grams ( $6 \frac{1}{2}$ ounces).

Type locality.-T'wenty miles south of Los Baños, Merced County [really near mouth of Little Panoche Creek in Fresno County], California (Taylor, 1916, p. 15).

Distribution.- Known as yet only from a limited section of the floor of the San Joaquin Valley within 35 miles south of Los Baños, in southwestern Merced County and northwestern Fresno County. Life-zone, Lower Sonoran.

Specimens examined.-A total of 34 from the following localities in California. Merced County : Sweeney's ranch in hills "22 miles soutb of Los Baños," 2. Fresno County: mouth of Little Panoche Creek, 18 or 20 miles south of Tos Baños, 29; Hayes Station, B. M. 502, on Panoche Creek, 19 miles southwest of Mendota, 2 ; one mile east of Mendota, 1.

The Los Baños Antelope Ground Squirrel very elosely resembles the Nelson Squirrel, and is doubtless practically identical with that form in general habits and locality preferences. More thorough exploration will probably show that the distribution of the two is continuous, in other words that the Los Baños race has resulted from a northward extension of the ancestral stock which has allowed the acquisition of the slight differences of greater size and paler tone of coloration which characterize amplus.

Along the western rim of the San Joaquin Valley south of Los Baños this subspecies is common locally. The type series was taken by R. H. Beck June 20, 1912, near the mouth of Little Panoche Creek, where the animals were found occupying holes on common territory with California Ground Squirrels. In one instance a "chipmunk" was shot at the same hole with a "ground squirrel."

Near the point where Panoche Creek breaks out of the hills, a few miles farther south, the last of June, 1918, museum collectors found a few Antelope Squirrels along roads between barley fields. The cheekponches of the two shot at the edge of such a field were full of barley grains. The breeding season on both the above dates was long passed; young were nearly or quite full-grown. Remains of Ammospermophitus were found about the month of the burrow of a kit fox, evidence of the identity of one kind of enemy.

The sort of country inhabited by this Ground Squirrel is arid and as yet to but a small extent under cultivation. Water is not available for extensive irrigation. The economic status already set forth for the Nelson Squirrel probably also holds for the Los Baños race. 


\section{SUMMARY OF POINTS OF SPECIAL IMPORTANCE FROM THE STANDPOINT OF GROUND SQUIRREL CONTROL.}

From the foregoing account of the natural history of the ground squirrels of California the following facts and inferences stand out as seemingly of special importance in connection with the determination and application of methods of ground squirrel control.

1. Of the eighteen kinds of ground squirrels occurring within the limits of the state, there appear to be only four meriting any particular consideration from an economic standpoint. These four are the California (or Beechey), the Oregon, the Fisher and the Douglas ground squirrels, here named in the estimated order of importance (see fig. 30). All the other fourteen kinds are, for the present at least, negligible, in most of the cases because they inhabit areas not cultivated by man.

2. The Oregon Ground Squirrel is less than half the size of a "digger" squirrel, but it is ordinarily present in nuch greater numbers per given area within its range (most of Siskiyou, Modoc and Lassen counties) than is any one of the "digger" squirrels in its range. The Oregon inhabits open grass lands and hence comes into sharp competition with cattle interests.

3. The Oregon Ground Squirrel is more of a grass eater than a seed or grain eater, and the most successful method of poisoning should involve the selection of an appropriate bait accordingly. It does not store up food to the extent that the "digger" squirrels do. The Oregon Ground Squirrel, more than any of the "digger" category, is subject to a sharply defined period of hibernation, and this involves all the individuals, of whatever age.

4. The California Ground Squirrel is our species of greatest aggregate numbers and is the one which is most widely distributed over the cultivated parts of the state. Its close relatives, the Fisher and Douglas ground squirrels, are known along with the California as "digger" squirrels; regarding most of the following considerations the three may be classed together.

5. Because of relatively large size the individuals of the "digger" category are able to inflict serious loss. Adults average $1 \frac{1}{4}$ to $1 \frac{1}{2}$ pounds in weight, and are easily able to consume $\frac{1}{2}$ ounce of dry grain or 2 ounces of green forage at a meal.

6. On open range and pasture lands these squirrels feed largely on alfilaria and bur clover, two of the most valuable forage plants in the state. The squirrels are then serious competitors for subsistence against the flocks and herds upon which man depends for his own support. On cultivated ground these squirrels feed upon or destroy in other ways grain and fruit crops to a very large extent where present even in numbers not above those reached on wild land. The tendency seems to be to increase to extraordinary numbers on cultivated lands unless effectively checked by man. This is due both to improvements of food conditions from the standpoint of the squirrel, and to removal of its natural enemies by man either purposefully or thoughtlessly. 
7. The food preferences of ground squirrels are strongly in evidence and vary from species to species, and sometimes within the same species, from place to place and season to season. It is common testimony of those who have practical experience in poisoning ground squirrels that the Douglas is much more easily handled than the California; in other words, the former takes the strychnine-coated barley more readily. It is obvious that the success of any method of control by the use of poison must depend importantly on the nature of the bait employed. The fact that in some places the California Ground Squirrel has been found to pass up barley altogether for the seeds of bur clover suggests a likely way of improving poisoning methods locally.

8 . In the "digger" category of ground squirrels there is evidence that a greater or less proportion of the population hibernates each winter. In the Douglas this feature of the annual activity of the animal is clearly evident, in that the majority, or at the higher altitudes all, of the individuals disappear for weeks or months together during the winter season. In the case of the California Ground Squirrel, however, numerous individuals are to be seen aboveground in the lower country in favorable weather at any time during the winter. But evidence at hand goes to show that these active individuals are chiefly young of the year and that most of the older squirrels are then lying dormant belowground, in some extreme cases for as long a period as from August to February. During this interval, therefore, any method of poisoning, and probably also of gassing, will obviously be ineffective upon a portion of the population, and this portion which escapes will reappear at the beginning of the next breeding season to reinfest the area concerned.

9. Some obstacles to the success of control by the method of gassing arise through the unequal extent and irregular course of the burrows of the squirrels. It was found that although the volumetric content of the burrows of the California Ground Squirrel excavated averaged 5.2 cubic feet, in one case an extreme of 17.8 cubic feet was reached. This obtained in one of the "colonial" types of burrows in which several establishments supposed to have been originally separate had come to be intercommunicating. It was found that the msual dosage was ineffectual in this case. There is no definite way of distinguishing such "colonial" bur"ows, from surface appearances alone. Then, again, in some burrows there is an abrupt rise in the underground course of the burrox, which prevents the onward flow of a gas heavier than air, such as carbon bisulphid, and the squirrel is not overtaken. In either of the above circumstances we find a reason for the partial failure of extensive gassing campaigns with current methods.

10. Ground squirrels reproduce rapidly. In the California the werage number of young in a litter is 7.2, with 4 and 11 as extremes. There is but one litter reared each year, and the young begin to appear aboveground about the first of May. The sexes are equally divided in a given population, and it is believed that each female breeds the first season of her life, that is, when she is slightly less than a year old, and that she has an "expectation" of rearing four more litters in case she lives to die of old age. Thus a population of 10 per acre in March may be expected to increase to 50 per acre by the last of May. Postponement of attention by the farmer is a losing proposition. A stitch in time actually saves nine. 
11. The general habits of ground squirrels are such that they were able to hold their own in the face of a host of natural enemies which habitually preyed upon them before the white man's advent. The squirrels are eminently successful in the battle for existence. They inevitably prosper when any natural check is removed.

12. The reemperative powers of ground squirrels are great. It is shown that if the population of one square mile (if estimated at 640 as in the case of the California Ground Squirrel) were subjected to two suecessive control campaigns, each of 90 per cent effectiveness, there would still remain six squirrels; these three pairs of squirrels would theoretically at the end of the third breeding season give rise to the full normal population of 640 , with a good margin for natural death. It would seem that, if absolute extermination prove not possible over any large area, eternal vigilance must be exercised to prevent the quick return of the squirrel population to the danger point. The squirrels must be looked after like weeds, which have to be dealt with year after year.

13. Ground squirrels breed upon uneultivated or waste land, from which they invade the cultivated fields within reach as well as such other lands as are not already fully populated. There is progressive emigration of a certain portion of the squirrel population each year, in August and September, involving ehiefly or entirely the young of the year just coming to maturity. By a process of gradual infiltration, land once thoroughly rid of squirrels may thus be reinfested from more or less distant areas of dissemination. Lands suceessfully poisoned in the spring may be found repopulated the following fall from some adjoining territory.

14. Sinee the squirrels if not interfered with by man are stopped in their emigrations only at some natural barrier, it seems clear that control eampaigns should not be limited by political or eivil boundaries such as state, county, district or property lines. Rather should natural

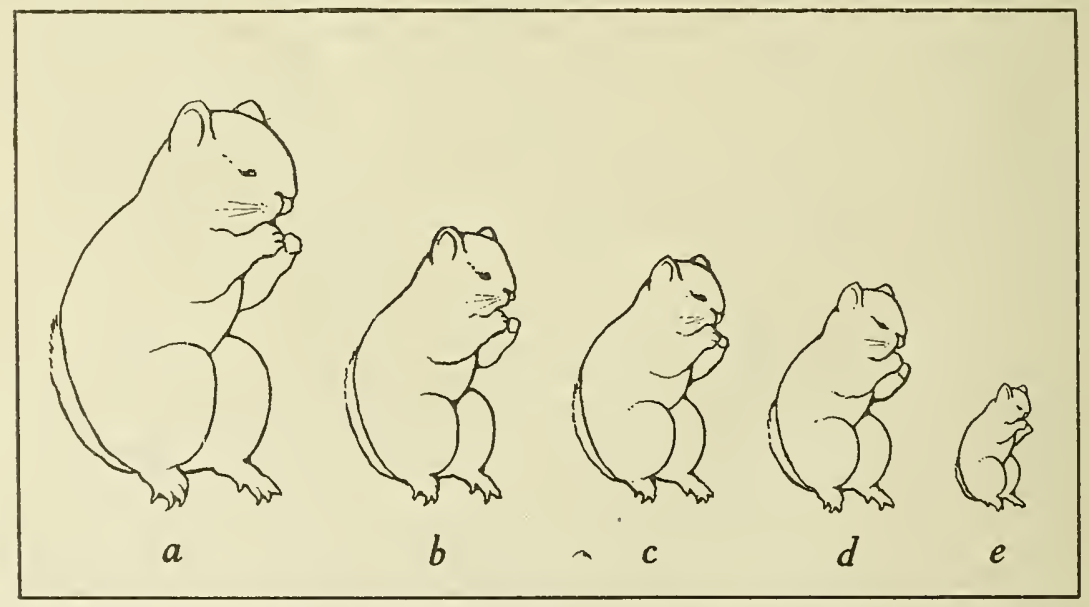

FIG. 30. Diagram showing estimated relative importance, as regards economic status, of the different species of ground squirrels in California. $a$, California (Beechey) Ground Squirrel; b, Oregon Ground Squirrel; $c$, Fisher Ground Squirrel ; d, Douglas Ground Squirrel; $e$, all other species of ground squirrels in the state put together. The estimated ratios are, respectively, $10-5-4-3-1$. 
barriers be hewn to, such as those of climate, seacoasts, rivers, brush lands and deserts. The forest ranger in anticipating the sweep of a potential fire, or in combating any actual fire, outlines his campaign irlespective of any but those lines which will naturally aid most in stopping the spread of the conflagration.

15. If "drive weeks" be advocated, as a popular measure to secure control locally, the time of the year selected should be fixed in accordance with the optimum chances for success, on the grounds of avidity of the squirrels for kinds of bait available, minimum natural population (previously to the time of appearance of the young), and probable weather conditions.

16. The above general remarks must not be construed as in any degree intended to discourage the continued energetic application of the best methods of ground squirrel control now in use. But it is hoped the facts and inferences set forth will convince the reader that the problem is not a simple one, and cannot be solved by casual, half-hearted measures. It is believed that great improvement can be secured both in devising of method and in mode of application.

Baird, S. F.

\section{IITERA'TURE CITED.}

1S57. Mammals of North America; the Descriptions of Species Based Chiefly on the Collections in the Museum of the Smithsonian Institution. U. S. Pac. R. R. Expl. and Surv., rol. S, Part I, pp. xxxiv +764, 60 pls.

Cary, M.

1911. A Biological Survey of Colorado. U. S. Dept. Agric., Bur. Biol. Surv., N. Amer. Fauna no. 33, 256 pp., 12 pls., 39 figs. in text.

Dixon, J.

1917. Control of the California Ground Squirrel. Univ. Calif. Agric. Exper. Sta., circ. no. 181,14 pp., 3 figs. in text.

Elliot, D. G.

1903. Descriptions of Twenty-seren Apparently New Species and Subspecies of Mammals. Field Columb. Mus., Zool. Ser., vol. 3, pp. 239-261, 2 figs. in text.

1904. Descriptions of Apparently New Species and Subspecies of Mammals and a New Generic Name Proposed. Field Columb. Mus., Zool. Ser., vol, 3: pp. $263-270$.

1904. Catalogue of Mammals Collected by E. Heller in Southern California. Field Columb. Mus., Zool. Ser., vol. 3, pp. 271-321, pIs. 38-49, 1 map.

Finley, W. L.

1906. The Golden Eagle. Condor, vol. S, pp. 4-11, 6 figs. in text.

Grinnell, J.

1908. The Biota of the San Bernardino Mountains. Univ. Calif. Publ. Zool., vol. 5, pp. 1-170, pls. 1-24.

1913. A Distributional List of the Mammals of California. Proc. Calif. Acad. Sci., 4th ser., vol. 3, pp. 265-390, pls. 15, 16.

1914. An Account of the Mammals and Birds of the Lorver Colorado Valley with Especial Reference to the Distributional Problems Presented. Univ. Calif. Publ. Zool., vol. 12, pp. 51-294, pls. 3-13, 9 figs. in text.

1918. Six new Mammals from the Mohave Desert and Inyo Regions of California. Univ. Calif. Publ. Zool. vol. 17, pp. 423-430.

Grinnell, J., and Grinnell, H. WV.

1907. Reptiles of Los Angeles County, California. Throop Inst. Bull., no. 35, 64 pp., 23 figs. in text. 
(irinnell, J., and Swarth, H. S.

1913. An Acconnt of the Birds and Mammals of the San Jacinto Alea of Souther'n California. with Remarks upon the Behavior of Geographic Races on the Margins of their Habitats. Univ. Calif. Publ. \%ool., rol. 10, pp. 197406 , pls. 6-10.

Long, J. D.

1912. A Squirrel Destructor. Public Health Reports (U. S. Public Health Service), vol. 27, no. 39, pp. 1594-1596, 7 figs. on 4 pls.

McCoy, G. W.

1912. Notes on the Bionomics of Rats and Ground Squirrels. Public Iealth Reports (U. S. Public Health Service), vol. 27, no. 2T, p1. 106S-1072.

Mearns, E. A.

1907. Mammals of the Mexican Boundary of the United States. U. S. Nat. Mus. Bull. no. 5̌6, Part I, pp. xv $+530,13$ pls., 126 figs. in text.

Merriam, C. H.

1SSS. Description of a New Spermophile from California. Innals N. I. Acad. Sci., vol. 4, pp. 317-321.

1SS9. Description of a New Spermophile from Southern California. T. S. Dept. Agric., Div. Orn. and Mam., N. Amer. Fauna no. 2, pp. 15-16.

1S59. Description of a New Species of Ground Squirrel from the Arid Lands of the Southrest. U. S. Dept. Agric., Div. Orn. and Mam.. N. Amer. Fauna no. 2, pp. 19-21.

1890. Descriptions of Three New Species of the Tamias lateralis Group. U. S. Dept. Agric., Div. Or'n. and Mam., N. Amer. Fauna no. 4, pp. 17-22.

1893. Descriptions of Eight New Squirrels of the Genera spormophilus and Tamias from California, Texas and Mexico. Proc. Biol. Soc. Tash. vol. S, pp. 129-13S.

1S98. Descriptions of Six New Ground Squirrels from the Wrestern United States. Proc. Biol. Soc. Wasl., vol. 12, pp. 69-71.

1901. Two New Rodents from Northwestern California. Proc. Biol. Soc. Wash., vol. 14 , pp. 125-126.

1910. The California Ground Squirrel. Circular no. 70, Bureau Biol. Surv., U. S. Dept. Agric., 15 pp., 4 figs. in text.

Nelson, E. W.

1915. Smaller Mammals of North America. Nat. Geog. Mag., rol. 33, pp. 371493,59 col. figs., 29 hft. figs., in text.

Iichardson, J.

1829. Fauna Boreali-Americana. (Loudon, John Murray), Part I, containing the Quadrupeds, pp. xlvi + 300 , 28 pls.

Riclgway, R.

1912. Color Standards and Color Nomenclature. (Washington. D. C.: published by the author), pp. $\mathrm{S}+44,53 \mathrm{col}$. pls.

Shaw, W. T.

1916. Ground Squirrel Control. Wash. Agr. Exper. Sta., Pop. Bull. no. 99, 11 pp.,

Stephens, I: 2 col. pls., 4 figs. in text.

1906. California Mammals. (San Diego, West Coast Publishing Co.), $351^{\circ}$ pp. frontispiece, $2 S$ figs. in text.

Stewart, G. R., and Burd, J. S.

1918. Control of Ground Squiruels by the Fumigation Method. Unir. Calif. Agric. Exper. Sta. Bull. no, 302, pp. 207-224. figs. 1-3.

'Taylor, W. P.

1916. A New Spermophile from the San Joaquin Valley, California, with Notes on Ammospermophilus nelsoni nelsoni Merriam. Univ. Calif. Publ. Zool., vol. 17. pp. 15-20, 1 fig. in text. 


PRESSBOARD

PAMPHLTT ENDER

Manufaclured be GAYLORD BROS. Inc.

Syracuse, N.Y.

Stockton, Calit. 
